Review

\title{
One Omics Approach Does Not Rule Them All: The Metabolome and the Epigenome Join Forces in Haematological Malignancies
}

\author{
Antonia Kalushkova ${ }^{1, *,+}\left(\mathbb{D}\right.$, Patrick Nylund ${ }^{1,+}+\mathbb{D}$, Alba Atienza Párraga ${ }^{1}\left(\mathbb{D}\right.$, Andreas Lennartsson ${ }^{2}$ and \\ Helena Jernberg-Wiklund ${ }^{1}$ (D)
}

1 Science for Life Laboratory, Department of Immunology, Genetics and Pathology, Rudbeck Laboratory, Uppsala University, 75185 Uppsala, Sweden; patrick.nylund@igp.uu.se (P.N.); alba.atienza-parraga@igp.uu.se (A.A.P.); helena.jernberg_wiklund@igp.uu.se (H.J.-W.)

2 Department of Biosciences and Nutrition, NEO, Karolinska Institutet, 14157 Huddinge, Sweden; andreas.lennartsson@ki.se

* Correspondence: antonia.kalushkova@igp.uu.se

+ These authors contributed equally to this work.

check for updates

Citation: Kalushkova, A.; Nylund, P.; Párraga, A.A.; Lennartsson, A.; Jernberg-Wiklund, H. One Omics Approach Does Not Rule Them All: The Metabolome and the Epigenome Join Forces in Haematological Malignancies. Epigenomes 2021, 5, 22. https://doi.org/10.3390/epigenomes 5040022

Academic Editor: Ernesto Guccione

Received: 14 July 2021

Accepted: 26 September 2021

Published: 8 October 2021

Publisher's Note: MDPI stays neutral with regard to jurisdictional claims in published maps and institutional affiliations.

Copyright: (c) 2021 by the authors. Licensee MDPI, Basel, Switzerland. This article is an open access article distributed under the terms and conditions of the Creative Commons Attribution (CC BY) license (https:/ / creativecommons.org/licenses/by/ $4.0 /)$.

\begin{abstract}
Aberrant DNA methylation, dysregulation of chromatin-modifying enzymes, and microRNAs (miRNAs) play a crucial role in haematological malignancies. These epimutations, with an impact on chromatin accessibility and transcriptional output, are often associated with genomic instability and the emergence of drug resistance, disease progression, and poor survival. In order to exert their functions, epigenetic enzymes utilize cellular metabolites as co-factors and are highly dependent on their availability. By affecting the expression of metabolic enzymes, epigenetic modifiers may aid the generation of metabolite signatures that could be utilized as targets and biomarkers in cancer. This interdependency remains often neglected and poorly represented in studies, despite well-established methods to study the cellular metabolome. This review critically summarizes the current knowledge in the field to provide an integral picture of the interplay between epigenomic alterations and the cellular metabolome in haematological malignancies. Our recent findings defining a distinct metabolic signature upon response to enhancer of zeste homolog 2 (EZH2) inhibition in multiple myeloma (MM) highlight how a shift of preferred metabolic pathways may potentiate novel treatments. The suggested link between the epigenome and the metabolome in haematopoietic tumours holds promise for the use of metabolic signatures as possible biomarkers of response to treatment.
\end{abstract}

Keywords: epigenetic; metabolite; gene regulation; haematological malignancies

\section{Different Levels of Epigenetic Regulation with the Ability to Orchestrate Gene Expression}

Methylation at the cytosine base of DNA $(5 \mathrm{mC})$ is the most studied epigenetic mechanism in both normal and cancerous cells. It plays numerous roles in promoter gene silencing, imprinting, X-chromosome inactivation, and genome stability, among others [1]. DNA methylation patterns are established primarily by the DNA methyltransferases 3A and 3B (DNMT3A and DNMT3B) [2], and maintained by the DNA methyltransferase 1 (DNMT1) [3]. Gene promoters contain CpG islands (CGIs), which are often unmethylated, whereas methylation of CGIs is associated with transcriptional silencing. CGIs constitute less than $10 \%$ of all CpGs in the human genome; the remainder are most often found methylated and exhibit a more diverse relationship with gene activation $[4,5]$. DNA demethylation occurs through passive dilution during cell division, but can also be initiated by the ten-eleven translocation (TET) family of dioxygenases through successive oxidization of $5 \mathrm{mC}$ to 5-hydroxymethylcytosine (5hmC), 5-formyl-cytosine (5fC), and 5-carboxylcytosine $(5 \mathrm{caC})$, which are excised and repaired to unmethylated cytosines by 
base excision repair [6-10]. Additionally, $5 \mathrm{hmC}$ itself has roles in modulating chromatin accessibility [11] and enhancer regulation $[7,12,13]$.

In addition to DNA methylation, post-translational modifications of the histone Nand C-termini tails play crucial roles in transcriptional regulation. The most studied histone modifications include methylation, acetylation, phosphorylation, and ubiquitination, and are broadly categorised as active or repressive, based on their effects on gene expression. These histone modifications are orchestrated by the corresponding histone-modifying enzymes; methyltransferases (HMTs or lysine methyltransferases, KMTs) and acetyltransferases (HAT) deposit methyl and acetyl groups, respectively, while demethylases (HDMs or lysine demethylases, KDMs) and deacetylases (HDACs) remove them. Additionally, kinases and ubiquitin ligases deposit phosphorylation and ubiquitination, respectively, on histone proteins. Gene repression is preferentially marked by trimethylation of histone H3 lysine 27 (H3K27me3) and lysine 9 (H3K9me3), and ubiquitination of histone H2A lysine 119 (H2AK119ub) [14]. The HMT responsible for the deposition of methyl groups to H3K27 is enhancer of zeste homolog $1 / 2$ (EZH1/2), the catalytic subunit of Polycomb repressor complex 2 (PRC2) [15], while histone H3K9 methylation is carried out by the HMT G9A (also known as euchromatic histone lysine methyltransferase 2 (EHMT2)) and is commonly associated with heterochromatin and transcriptional repression. On the opposing side, gene activation is typically supported by the trimethylation of histone $\mathrm{H} 3$ at lysine 4 (H3K4me3), lysine 36 (H3K36me3), and lysine 79 (H3K79me3), the acetylation or phosphorylation of histone $\mathrm{H} 3$ and histone $\mathrm{H} 4[16,17]$, and the ubiquitination of histone $\mathrm{H} 2 \mathrm{~B}$ at lysine 120 (H2BK120ub). The H3K4me3 marks are commonly found at active promoters, whereas acetylation of $\mathrm{H} 3 \mathrm{~K} 27$ is found at both promoter and enhancer regions [18]. The HMT mixed-lineage leukaemia (MLL, also known as lysine methyltransferase 2A (KMT2A)) has the ability to catalyse mono-, di-, and, to a lesser extent, trimethylation of histone H3K4 [19-23], and plays a pivotal role in haematological malignancies, as described below.

An additional level of epigenetic gene regulation consists of non-protein-coding RNAs, of which the most well-studied are the microRNAs (miRNAs). MicroRNAs are a class of small RNAs (15-25 nucleotides in length) with a "seed" sequence complementary to the untranslated $3^{\prime}$ UTR region of the target mRNA. MicroRNA binding to its cognate target most commonly leads to transcript degradation and/or transcriptional suppression, thus negatively regulating gene expression at the mRNA level. Transcription of miRNAs originates at various genomic locations, i.e., intergenic, exonic, or intronic. Upon transcription by RNA polymerase II, the pri-miRNA's lower stem-loop structure is bound by the RNA-binding protein DGCR8 and cleaved away by the ribonuclease III enzyme DROSHA, releasing a small hairpin structure of the newly formed pre-miRNA. The pre-miRNA is then exported to the cytoplasm, where another ribonuclease III enzyme DICER, recognizes the two-nucleotide overhang generated by DROSHA and cleaves the pre-miRNA near the terminal loop, generating a small miRNA-miRNA duplex. This duplex is then loaded onto the RNA-induced silencing complex (RISC), which removes the passenger strand to generate a mature miRNA that is specific to the targeted mRNA [24,25].

\section{Epigenetic Alterations in Haematopoietic Tumours}

\subsection{DNA Methylation Dysregulation in Haematological Malignancies}

Aberrations in the DNA methylome are well-described in haematological malignancies. A large heterogeneity has been described for several types of leukaemia, both within and between patient samples [26-29]. The DNA methylation variability increases with disease progression and has a clinical and functional impact on acute myeloid leukaemia (AML), diffuse large B-cell lymphoma (DLBCL), follicular lymphoma (FL), and chronic lymphocytic leukaemia (CLL) [26-29]. Much of this variability is currently considered to arise stochastically; however, Pan et al. have recently provided evidence for the promoter methylation of DUSP22, RPRM, and SASH1 to drive disease progression and relapse in CLL [30]. Furthermore, promoter-specific DNA hypermethylation has been associated with chemotherapy resistance in DLBCL [31]. The disturbed DNA methylome is often 
associated with underlying genetic alterations in enzymes involved in DNA methylation, such as DNMT3A and isocitrate dehydrogenase 1/2 (IDH1/2) [32-34].

DNMT3A mutations occur in about $20 \%$ of patients with AML and about $17 \%$ of patients with T-cell acute lymphoblastic leukaemia (T-ALL), and are associated with poor disease outcome [35-38]. DNMT3A mutations have also been reported in myelodysplastic syndromes (MDS), chronic myelomonocytic leukaemia (CMML), and myeloproliferative neoplasms (MPN) [38]. The most common DNMT3A mutations impair DNMT3A methyltransferase activity and lead to CpG-specific hypomethylation [32]. DNMT3A mutations are thought to arise early during the AML evolution and lead to increased numbers of preleukaemic stem cells that can later evolve into AML [39]. On the other hand, DNMT1 and DNMT3B are overexpressed in T-ALL, Burkitt's lymphoma, and DLBCL, where the overexpression is associated with advanced clinical stages and poorer responses to chemotherapy and /or radiotherapy [40-42].

Mutations in DNA methylation modifiers are present in about $4 \%$ of multiple myeloma (MM) patients at diagnosis and are associated with shorter overall patient survival. These include mutations in DNMT3A, TET2, and IDH1/2 [43]. These mutations are similarly represented in human MM cell lines [44]. Although global hypomethylation in MM is associated with disease progression [45] and poor prognosis [46], at the gene-specific level, both hypo- and hypermethylation events have been linked to the regulation of genes important for MM. Hypomethylation of promoters has been suggested to be an early event in MM pathogenesis by facilitating interleukin 6 (IL-6) production [47], and has also been linked to drug resistance [48]. In turn, DNA hypermethylation in MM has been reported at numerous gene promoters [49], for some of which it is associated with shorter overall patient survival [50] and has been shown to accumulate during the course of the disease [51,52]. Notably, MM has been shown to regain high methylation levels at B-cell specific enhancers, which normally become demethylated during plasma cell differentiation, thus suggesting that MM may retain properties of early stages of haematopoietic cell differentiation [53]. DNA methylation patterns have also lately been shown to be useful in differentiating between the different molecular subgroups in newly diagnosed MM patients and to be tightly linked to chromatin modification patterns, where hypomethylated regions overlap with enrichment of H3K27me3 [54]. Recently, new data indicate that $\mathrm{MM}$ presents with reduced levels of $5 \mathrm{hmC}$ compared to normal plasma cells, and higher levels of $5 \mathrm{hmC}$ in MM patients were associated with early disease stages and longer overall patient survival [55]. Notably, $5 \mathrm{hmC}$ is thought to regulate the activity of enhancers and superenhancers in MM [56].

The gene encoding the DNA demethylating enzyme TET2 is mutated in $10-20 \%$ of AML cases, resulting in an unfavourable disease outcome [57-59], as well as $10-20 \%$ of MDS/MPN patients [60,61], 40-50\% of patients with CMML [59,62], and about $10 \%$ of DLBCL patients [63]. Inactivation of TET2 perturbs early and late steps of myeloid and lymphoid differentiation in mice leading to the development of malignancies in these lineages [63]. During the germinal centre (GC) exit phase of B cell maturation, loss of TET2 leads to a decrease in enhancer $5 \mathrm{hmC}$ and the subsequent transcriptional repression of genes that guide the GC exit. This disrupts the differentiation of B cells in the GC, leading to GC hyperplasia, impaired class-switch recombination, and lymphomagenesis. The genes silenced due to TET2 impairment overlap with those normally activated by cAMP-response elementbinding protein $\mathrm{B}$ (CREBB)-mediated histone acetylation, and mutations in TET2 and CREBB are largely mutually exclusive [64]. Restoration of TET2 activity in leukaemic stem cells blocks cell self-renewal-specific DNA methylation and promotes differentiation [65]. Almost entirely mutually exclusive with TET2 mutations in AML are mutations in IDH1/2, which are associated with adverse prognosis [66-68]. This selection for either mutant IDH1/2 or TET2 enzymes suggests a dominant transforming effect in AML [69]. IDH1/2 mutations confer neomorphic enzyme activity, which leads to the synthesis of (R)-2-hydroxyglutarate (2-HG) [70-72]. 2-HG competitively inhibits TET enzymes and histone lysine demethylases of the Jumonji family, resulting in loss of $5 \mathrm{hmC}$, gain of $5 \mathrm{mC}$, gain of histone methylation, 
and a block in hematopoietic differentiation [69,73-76]. Notably, higher methylation levels are observed in mutant IDH than in mutant TET2 AML [76]. Thus, the combinatorial inhibition of IDH1 and DNMTs is suggested as a potent novel strategy for the treatment of IDH mutant AML [77].

\subsection{Dysregulations of Histone Modifiers in Haematological Malignancies}

Mutations in chromatin modifiers are common in haematological malignancies; for example, over half of MM patients are estimated to have mutations in chromatin modifiers [78]. The MLL H3K4 methyltransferase gene was identified as a recurrent target of chromosomal translocations of the long arm (q) of chromosome 11 at band q23 in acute leukaemias, including infant, paediatric, adult, and therapy-induced AML, ALL, and acute biphenotypic leukaemia (ABL) [79-82]. In haematological malignancies, the MLL rearrangements are mostly associated with very poor prognosis, and more than 70 translocation partners to MLL have been reported $[83,84]$. Of these, many are themselves components of the transcriptional machinery, e.g., ELL, ENL, AF4, AF9, AF10, and CBP, or the fusion has been reported to recruit transcriptional regulators, e.g., P-TEFb, DOT1L, and Polycomb group proteins [85-91]. Recently, the lysine acetyltransferase KAT7, through H3K14 and H4K12 acetylation, was found to provide a platform for recruitment of the MLL fusion proteins and be essential for the proliferation of AML cells [92]. The profound transcriptional dysregulation observed in MLL-rearranged leukaemias makes it an attractive target for innovative treatment strategies [93-95].

Mixed-lineage leukaemia 3 (MLL3, also known as KMT2C) and mixed-lineage leukaemia 4 (MLL4, also known as KMT2D) are involved in depositing the bulk of monomethylation on $\mathrm{H} 3 \mathrm{~K} 4$ at gene enhancers and are frequently mutated in haematological malignancies [96]. The MLL3 mutations/deletions are found in 15\% of DLBCL, MDS, and AML [97-99]. MLL4 mutations are observed in non-Hodgkin lymphoma (NHL) [98,100-102], ALL [103-105], and AML [106]. Mutant MLL3 and MLL4 are both suggested to contribute to lymphomagenesis in haematological cancers via the abrogation of enhancer functions during haematopoietic differentiation [107]. Lack of MLL4 impedes B-cell differentiation and class-switch recombination in the GC by perturbing $\mathrm{H} 3 \mathrm{~K} 4 \mathrm{me} 3$ at target genes, some of which are known to be tumour suppressors or involved in B-cell receptor signalling pathways [108,109]. Mutations in MLL4 in human MM cell lines are suggested to contribute to resistance to dexamethasone, but also to confer sensitivity to lenalidomide [110].

Among other alterations in methyltransferases in haematological malignancies are mutations in the PRC2 methyltransferase EZH2, which deposits H3K27me3. As a matter of fact, EZH2 is the most frequently mutated Polycomb member in blood cancers [111,112]. Loss-of-function and missense mutations in EZH2 occur in AML [113,114], MDSs, CMML, primary myelofibrosis (PMF), and T-ALL [113,115-119]. Inactivating mutations of EZH2 predict a poorer overall outcome in CMML, MDS, and PMF [120,121]. Heterozygous somatic mutations of EZH2 within the histone methyltransferase (SET) domain occur in up to $30 \%$ of FL and GCB-DLBCL [122-125]. Unlike in the above cases, these are gain-of-function alterations, providing EZH2 with increased efficiency for H3K27me3 deposition and decreased efficiency for H3K27me1 deposition [126-128]. Expression of the heterozygous mutant EZH2 in GC B cells in mice leads to hyperplasia and B-cell lymphoma through silencing of target genes involved in cell cycle regulation and GC exit $[129,130]$. However, a wild-type Ezh2 allele is required for this malignant transformation, as the phenotype of a homozygous mutant Ezh2 resembles EZH2 loss-of-function [130]. EZH2 plays a pivotal role in guiding plasma cell differentiation, where its catalytic activity is required for preserving the preplasmablast proliferative state, and its inhibition stimulates normal plasma cell differentiation [131]. In MM, EZH2 has been defined, by our group and others, as an oncogene [132], and its overexpression is associated with poor prognosis [133]. Interestingly, no EZH2 mutations have been identified in MM to date, despite evaluation in a large number of patient samples and cell lines $[43,134]$. We were the first to report that the EZH2-mediated H3K27me3 deposition marks a set of genes commonly silenced 
in MM patients, which is also found within a signature previously associated with poorly differentiated aggressive tumours [135]. Furthermore, the silencing of the H3K27me3 targets correlates with advanced stages of the disease and poor survival [134]. These findings have led to the establishment of PRC2-mediated gene targeting as a potential therapeutic target in MM [133-144]. Combinatorial inhibition of EZH2 and DNMTs has also been suggested as a therapeutic strategy in AML [145].

In MM, mutations are observed in the H3K36me1/2 methyltransferases nuclearreceptor-binding SET domain 1 (NSD1), multiple myeloma SET-domain-containing protein (MMSET, also known as NSD2 and WHSC1), nuclear-receptor-binding SET domain 3 (NSD3, also known as WHSC1L1) [43,146], and the H3K36me3 methyltransferase SET-domaincontaining 2 (SETD2). Mutations in NSD1 and SETD2 are either exclusively found or significantly enriched in relapsed MM patients, suggesting a role in chemotherapeutic resistance $[43,78]$. In about $5 \%$ of AML cases, a chromosomal translocation fuses NSD1 to NUP98 to generate a NUP98-NSD1 chimera, which is sufficient to induce AML in vivo [147,148]. Furthermore, a gain-of-function point mutation in the catalytic domain of MMSET is found in MM [149]. Additionally, in about $15 \%$ of MM cases, MMSET is overexpressed as a consequence of the chromosomal translocation $\mathrm{t}(4 ; 14)$, which is associated with an adverse prognosis [150]. MMSET overexpression leads to a genome-wide increase in H3K36me2, which generates a transcriptional profile supporting myelomagenesis [151]. This increase in H3K36me2 leads to reduced global levels of H3K27me3, as well as its focal redistribution, which is thought to support MM tumourigenesis, as MMSET overexpression results in increased sensitivity to EZH2 inhibition [152,153].

Additionally, homozygous and heterozygous inactivating mutations in the H3K27me3 demethylase ubiquitously transcribed tetratricopeptide repeat on chromosome X (UTX, also known as KDM6A) have been identified in a small proportion of AML [154,155], MM lacking the chromosomal translocation $t(4 ; 14)$, and T-ALL $[146,156]$, but not lymphomas that harbour EZH2 gain-of-function mutations [100]. In mice, Utx knockout induces spontaneous AML through global changes in H3K27 acetylation, as well as H3K4me1, ETS, and GATA binding, among others [157]. Loss of UTX in MM is thought to contribute to the malignancy by maintaining $\mathrm{H} 3 \mathrm{~K} 27 \mathrm{me} 3$ gene repression, which is amenable to reactivation by EZH2 inhibition [158]. Furthermore, members of the lysine methyltransferase 2 (KMT2) family, which are known to act within a multiprotein complex together with UTX $[159,160]$, are mutated in about $5-7 \%$ of MM patients $[43,146]$. Interestingly, germline autosomal dominant mutations in the lysine-specific histone demethylase 1A (LSD1, also known as KDM1A) are the first genetic alterations identified to predispose to familial MM [161].

Elevated levels of class I HDACs, particularly HDAC1, are associated with poor prognosis in MM patients [162]. Additionally, the HDAC class III sirtuin 6 (SIRT6) is overexpressed in MM and AML samples and has been described to promote adaptive genomic stability $[163,164]$. Recently, extensive aberrant chromatin activation marked by H3K27 acetylation was described as another unifying event in MM and was suggested to underlie crucial signalling pathways that shape the malignant plasma cell phenotype [165]. This is supported by the fact that the use of HDAC inhibition has been shown to exhibit antimyeloma effects through varying modes of action [166], and, as such, the HDAC inhibitor panobinostat is an approved treatment of $\mathrm{MM}$ in combination with standard therapies [167].

\subsection{The Roles of miRNAs in Haematological Malignancies}

Aberrations of miRNA expression, biogenesis, and consequent gene silencing are associated with the entire spectrum of haematological malignancies [168,169]. Expression profiling of miRNAs in blood cancers suggests their involvement as both oncogenes and tumour suppressors [170-173]. Their role often seems to be cell-type and/or context-dependent, and, as primarily based on sequence complementarity, it would also be influenced by any potential translocations and/or sequence variations, making the field particularly difficult to summarise. The myriad of functions of miRNAs can also be exemplified by 
their role as biomarkers for disease, treatment response, and/or disease outcome. In CLL, for example, the expression of miRNAs has been used for the fine-tuning of disease stratification $[174,175]$. In MM, miRNA expression signatures have been associated with the different genetic subtypes [176,177], and also suggested as regulators of the normal and malignant plasma cells [178]. Overexpression of miR-155 is described in CLL, B-cell lymphomas, including DLBCL, and cutaneous T-cell lymphoma (CTCL) $[173,179,180]$. In CTCL, miR-155 is involved in tumour progression [181]. In AML, miR-155 is induced by FLT3-ITD signalling and functions through targeting the transcription factor PU.1 [182]. Conversely, miR-155 has been reported to have an antileukemic role in FLT3-wild-type AML by inducing apoptosis and myelomonocytic differentiation [183]. It has also been suggested as a marker for the risk of progression from monoclonal B-cell lymphocytosis (MBL) to CLL, as well as for poor response to treatment [184]. In DLBCL, miR-155, miR-21, and miR-221 are overexpressed, and the higher expression discriminates the ABC-type immunophenotype from the GCB-type, whereas miR-21 expression is an independent prognostic indicator in de novo DLBCL [185]. In AML and ALL, overexpression of the miR-17-92 cluster is caused by either copy number amplification or direct targeting by MLL fusions, leading to increased cell proliferation and inhibition of apoptosis, suggesting that miR-17-92 may play a role in the development of MLL-rearranged leukaemia [186]. MiR-150 has been reported to be overexpressed in CLL [173] and underexpressed in chronic myelogenous leukaemia (CML), where its decreased levels are suggested to potentiate MYB and BCR-ABL expression [187]. In acute promyelocytic leukaemia, treatment with the differentiating all-trans-retinoic acid results in upregulation of potential tumour suppressor miRNAs, such as miR-15a, miR-15b, miR-16-1, let-7a-3, let-7c, let-7d, miR-223, miR-342, and miR-107 [188]. Reduced expression of let-7a has also been correlated with CLL pathogenesis [170]. MiR-143 and miR-145 are underexpressed in a variety of B-cell malignancies, including B-cell lymphomas, CLL cell lines, and transformed B-cell lines, suggesting that their differential expression may be used as a biomarker for malignant B cells [189]. MiR-181a has been identified as specific to B-lymphoid cells of the bone marrow, and its ectopic expression in progenitor cells leads to an increased fraction of cells within the B-cell lineage [190]. Elevated expression of miR-181a in AML can discriminate between morphological French-American-British (FAB) phenotypes and associates with the highest number of significantly correlated genes, suggesting a wide regulatory network underlying the disease [191]. Furthermore, distinct miRNA expression can distinguish AML cases with common translocations, suggesting that these miRNAs may play a role in the development of leukaemia with the associated genetic background [192]. Reduced expression of miR-204 is observed in AML, where its overexpression leads to cell apoptosis by targeting BIRC6 [193]. Moreover, expression of miR-204 potentiates sensitivity of AML cells to arsenic trioxide [194]. Overexpression of miR-125a/b in AML and MDS also exerts antioncogenic and prodifferentiation effects by modulating the NF- $\mathrm{KB}$ signalling pathway [195-197]. In MM, we have shown that the antiproliferative effects of EZH2 inhibition are concurrent with downregulation of known MM oncogenes, such as IRF-4, XBP-1, PRDM1, and MYC, which is potentially mediated by the induced expression of miR-125a-3p and miR-320c [172].

\section{The Cellular Metabolism in Haematological Malignancies}

As cancer cells acquire a cellular advantage over noncancerous cells, metabolic adaptations are required to meet the increasing need for core metabolic intermediates and macromolecules, as well as to avoid programmed cell death [198]. While multi-omics analyses of various cancers have revealed a complex and often heterogeneous pattern of clonal mutations granting a proliferative advantage [199], metabolic adaptation is widely observed across multiple malignancies and is considered to be a hallmark of cancer [200]. Furthermore, genetic alterations, including epimutations in different layers of epigenetic regulation, have an impact on the different pathways of cancer metabolism [201-203]. The metabolic landscape is also, in a large part, determined by the hypoxia-inducible factor 
1-alpha (HIF-1 $\alpha$ ) in the hypoxic tumour environment, MYC, and other signalling pathways, including the phosphatidylinositol 3-kinase (PI3K)-AKT, NOTCH, and the mammalian target of rapamycin (mTOR) [204-211]. Therefore, the metabolic landscape for each tumour type cannot easily be described without putting it into context with cell type, mutations, epimutations, and tumour microenvironmental factors [212].

Normal cellular functions dictate that energy is obtained from the generation of ATP through oxidative phosphorylation by the mitochondrial metabolism of pyruvate. However, tumour cells favour the less effective process of anaerobic glycolysis for generating ATP, which then produces lactate as a byproduct. Although the tumour microenvironment is often hypoxic, thus favouring glycolysis, cancer cells use glycolysis even when oxygen is abundant. This phenomenon, termed the Warburg effect [213], provides the cancer cells with enough reduced NADPH and glycolytic intermediates to sustain the increased need for biomolecule synthesis. In addition to the glycolytic switch, cancer cells also upregulate their glucose uptake and are prone to activate the use of alternative carbon sources (Figure 1).

In haematological malignancies, the glycolytic switch has been well-described and is often attributed to underlying genetic alterations or essential cancer drivers. One of the most commonly altered signalling pathways in cancer is the PI3K pathway, which converges in the activation of AKT and mTOR. The PI3K/AKT/mTOR pathway has previously been associated with the regulation of pathways involving glucose uptake and glycolysis in cancer [214]. In AML, PI3K/AKT/mTOR signalling activates glycolysis [207,208]. Among others, PI3K/AKT/mTOR downstream signalling regulates the activity of HIF- $1 \alpha$, an important player in the metabolic shift from oxidative phosphorylation to glycolysis by regulating the expression of hexokinase 1 (HK1), hexokinase 2 (HK2), lactase dehydrogenase A (LDHA), glucose transporter type 1 (GLUT1), and pyruvate dehydrogenase kinase 1 (PDK1), all of which are vital regulators of glycolysis $[215,216]$ (Figure 2). The activation of PDK1 results in inhibition of pyruvate dehydrogenase (PDH), thus leading to a reduced production of tricarboxylic acid (TCA) cycle substrates and, in turn, promoting glycolysis. PDKs have been shown to have important roles in disease pathogenesis in several haematological malignancies, such as CLL, AML, and CML [217-219]. Furthermore, MYC co-operates with HIF- $1 \alpha$ to promote activation of the glucose transporters HK2, LDHA, and PDK1, thereby stimulating the metabolic shift from oxidative phosphorylation to glycolysis in many cancers [216,220,221]. In MLL-rearranged leukaemia, increased glycolytic activity in combination with increased levels of HIF- $1 \alpha$ leads to resistance to inhibition of mitochondrial respiration [222], whereas inhibitors against HIF-1 $\alpha$ are currently in development and have been proven to have antitumour activity in MM [223]. Furthermore, in $\mathrm{MM}$, this metabolic reprograming may be induced by the cytokine-induced oncogenic phosphatase PRL-3 through activation of STAT1 and STAT2 transcription factors [204,205] and by cyclin D1 through targeting HK2 [206]. In MLL-AF9-induced murine AML, glycolysis is supported by AMP-activated protein kinase (AMPK) [209], whereas, in T-ALL, glycolysis is supported by the oncogenic NOTCH [210,211]. Interestingly, in B-ALL- and BCR-ABL-driven CML, inhibition of cyclin-dependent kinases (CDKs) has been shown to restrain glycolytic metabolism by a suggested mechanism involving downregulation of MYC and the rate-limiting enzymes GLUT1, HK2, and LDHA [224,225]. 


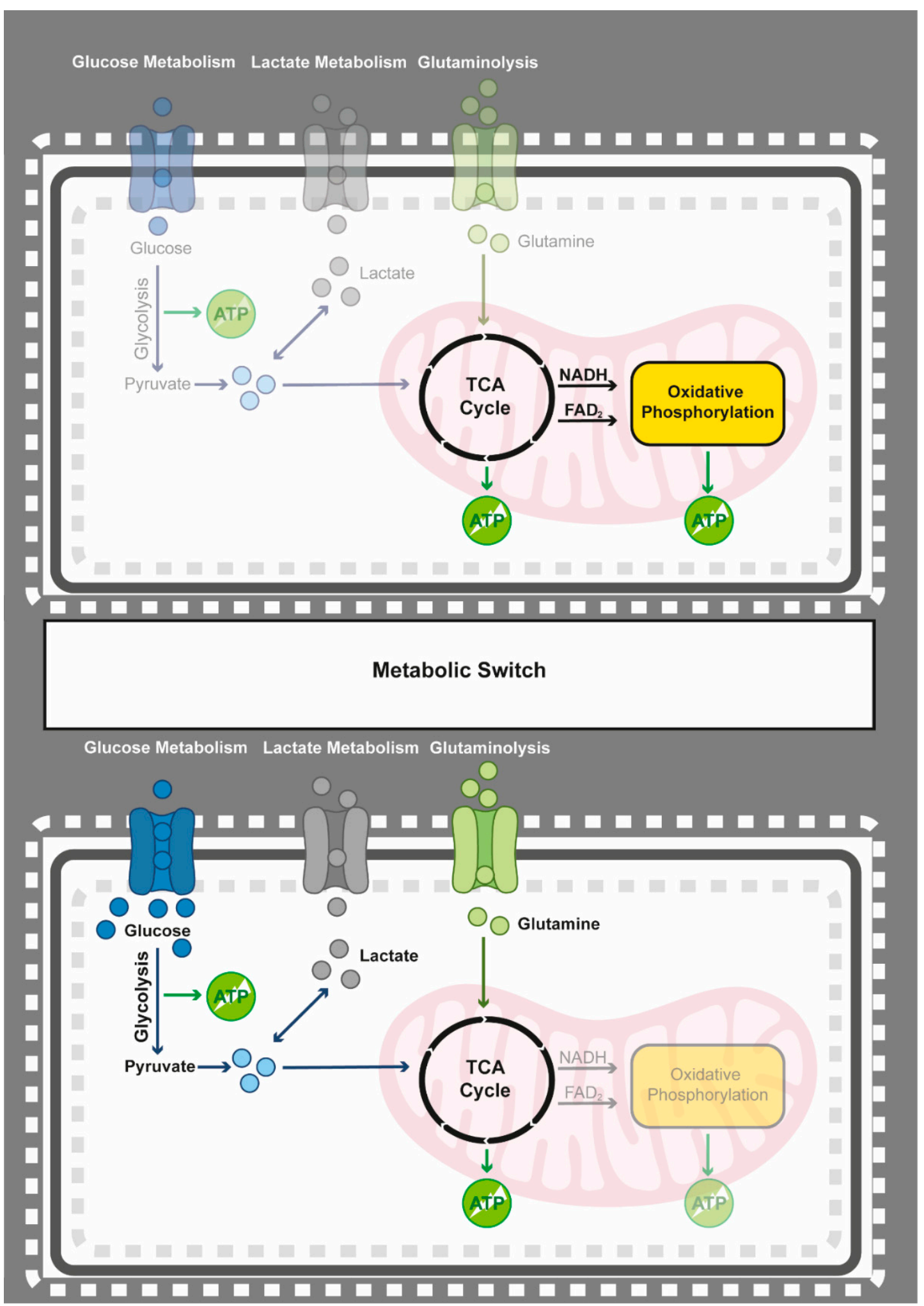

Figure 1. Schematic representation of the metabolic shift from oxidative phosphorylation to glycolysis. In the presence of oxygen, normal cells metabolise their glucose to pyruvate, which is then completely oxidised to $\mathrm{CO}_{2}$ and $\mathrm{H}_{2} \mathrm{O}$ via the TCA cycle and oxidative phosphorylation. Only under hypoxic conditions will normal cells reduce pyruvate to lactate through anaerobic glycolysis. Cancer cells, however, convert pyruvate into lactate, even in the presence of oxygen. In addition, while increased glucose uptake contributes to increased energy production, additional carbon sources, such as lactate and glutamine metabolism, are required to promote the synthesis of biomolecules required for rapid proliferative capacity. 


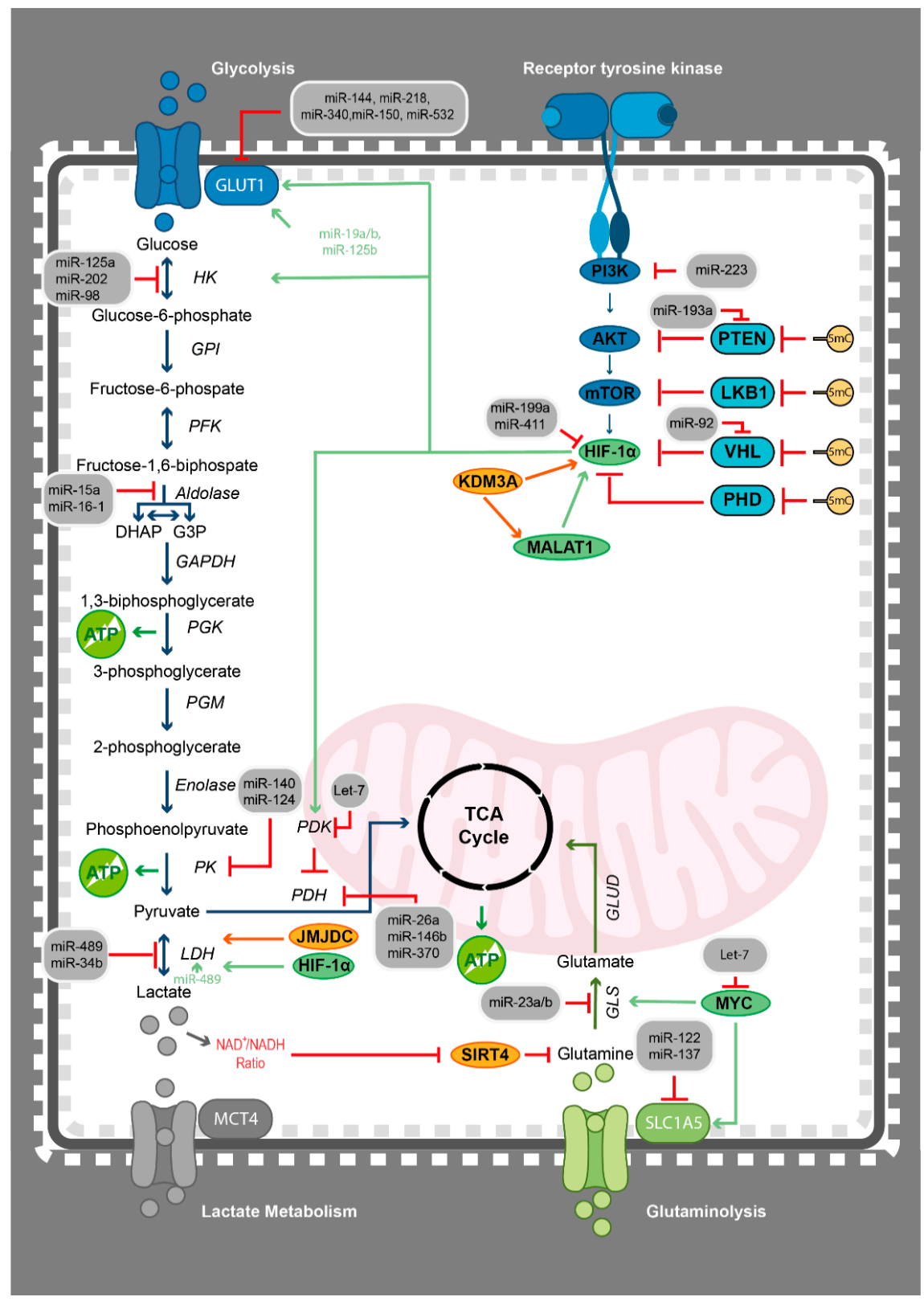

Figure 2. The complex regulatory network of glycolysis, lactate metabolism, and glutaminolysis is highly dependent on activation of the transcription factor HIF-1 $\alpha$ to promote the metabolic shift from oxidative phosphorylation to glycolysis. HIF-1 $\alpha$ participates in the glycolytic switch by regulating the expression of glucose transporters and enzymes in the glycolysis pathways. In haematological cancers, the H3K9 demethylase KDM3A contributes to an active HIF-1 $\alpha$ phenotype and enhancement of glycolysis, while DNMT3A mediates the silencing of HIF- $1 \alpha$ negative regulators. Additionally, miRNA regulation has a large impact on glycolysis and the access to intermediate biomolecules. MiRNAs can affect large portions of glycolysis, lactate metabolism, and glutaminolysis, which unveils a complex regulatory structure whereby miRNAs can both function as oncogenes and tumour suppressors. Red lines indicate a silencing effect. Green arrow indicates a promoting effect. All other arrows indicate enzymatic activity. GLUT1, glucose transporter type 1; HK, hexokinase; GPI, phosphoglucose isomerase; PFK, phosphofructokinase; GAPDH, G3P dehydrogenase; PGK, phosphoglycerate kinase; PGM, phosphoglyceromutase; PK, pyruvate kinase; LDH, lactate dehydrogenase; MCT4, monocarboxylate transporter 4; PDK, pyruvate dehydrogenase kinase; PDH, pyruvate dehydrogenase E1; HIF-1 $\alpha$, hypoxia-inducible factor 1-alpha; JMJDC, jumonji domain; SIRT4, sirtuin 4; SLC1A5, solute carrier family 1 member 5; GLS, glutaminase; GLUD, glutamate dehydrogenase; KDM3A, lysine demethylase 3A; LSD1, lysine demethylase 1A; PHD, prolyl hydroxylase domain; VHL, von Hippel-Lindau; LKB1, serine/threonine kinase 11; PTEN, phosphatase and tensin homolog; mTOR, mechanistic target of rapamycin kinase; and $\mathrm{AKT}, \mathrm{AKT}$ serine/threonine kinase. 
An additional alternative to meet the increased energy requirement of a highly proliferative cancer cell is to increase the glucose uptake. However, glucose cannot readily cross the plasma membrane of its own accord and is, thus, dependent on active transport by GLUT1, among others. GLUT1 inhibition reduces glucose uptake, resulting in increased apoptosis, and contributes to chemotherapy sensitivity in haematological cancers, such as MM and AML [226,227]. The glucose uptake in MM, has also been shown to further rely on the glucose transporter type 4 (GLUT4), targeting of which may present, as yet, an alternative treatment approach [228]. Interestingly, AML patients show signs of glucose insufficiency in the bone marrow microenvironment [229]. To overcome such glucose depletion, AML cells may utilise fructose through the upregulation of the fructose transporter GLUT5, and, as such, treatment with the fructose analogue 2,5-anhydro-d-mannitol (2,5-AM) prevents cellular proliferation in AML [229]. Alternatively, an increase in glucose uptake may be mediated by the ROS-driven upregulation of the glycolytic enzyme PFKFB3 in AML [230]. Notably, targeting glycolysis directly by using the glucose analogue 2-deoxyglucose (2-DG) has been shown to resensitise ALL cells to prednisolone treatment, albeit with severe side effects [231]. Increased glucose uptake will generate increased pyruvate that can be converted to lactate by LDHA, while generating acetyl-CoA. In fact, increased lactate production has been described in MM in combination with expression of the monocarboxylate transporter 4 (MCT4), resulting in increased lactate in the tumour microenvironment [232]. Increased lactate levels in haematological diseases could be considered as a potential marker for glycolysis-targeted intervention. Additionally, tumour cells may also activate the use of alternative carbon sources, e.g., glutamine, which can be further converted into $\alpha$-ketoglutarate $(\alpha-K G)$ in the TCA cycle.

In contrast to the bulk of tumour cells, cancer stem cells are more dependent on oxidative phosphorylation. Indeed, metabolic analysis of leukaemia stem cells in de novo AML samples revealed that they are highly dependent on amino acid metabolism to drive oxidative phosphorylation $[233,234]$. Similarly, in B-ALL, a small population of stem-cell-like leukaemia-initiating cells displayed a preference in the use of oxidative phosphorylation. These cells were more resistant to cytosine arabinoside (Ara-C) treatment, an effect that could be reverted by the pharmacological inhibition of oxidative phosphorylation [235]. Similar results were shown for leukaemic stem cells in CML with minimal residual disease [236]. Furthermore, T-ALL cells have also shown dependency on oxidative phosphorylation and sensitivity towards its inhibition [237]. Additionally, CLL cells were characterised with increased oxidative phosphorylation, but not increased aerobic glycolysis [238], whereas MM cells are suggested to rely on both glycolysis and oxidative phosphorylation $[239,240]$.

The conversion of pyruvate during oxidation of glucose, glutaminolysis, and $\beta$ oxidation of fatty acids generates acetyl-CoA, another important molecule for the cancer cells. Acetyl-CoA is a vital molecule, as it serves as an intermediary for many metabolic pathways. Acetyl-CoA rarely moves across the mitochondrial membranes due to its polarity, so, to overcome this limitation, acetyl-CoA and oxaloacetate generate citrate in the TCA cycle, which is then translocated into the cytoplasm via the malate-citrate antiporter system (Figure 3). Citrate is then used to produce acetyl-CoA and oxaloacetate by ATP-citrate lyase (ACL) [241]. In AML, low expression of ACL has been linked to favourable prognosis [242]. Acetyl-CoA can also be synthesised from glycolysis-derived pyruvate by the action of PDH. However, active HIF-1 signalling, a common feature in haematological diseases, activates PDK and, thus, inhibits pyruvate kinase (PK) and results in less pyruvate being shuffled into the mitochondria for TCA-mediated acetyl-CoA production. In these conditions, the predominant source of acetyl-CoA is the catalysation of acetate by acetyl-CoA synthetase (AceCS) in the cytoplasm or mitochondria $[243,244]$ (Figure 3). AceCS2 overexpression in $\mathrm{MM}$ has been reported to contribute to disease pathogenesis [245]. Interestingly, in a subset of MM patients, AceCS1/2 expression is increased, while levels of ACL and PDH are reduced, indicating a preferential use of acetate as a source of acetyl moieties and pointing towards a possible therapeutic vulnerability [245]. Other modes of acetyl-CoA production 
have been observed in haematological diseases. For instance, in glucose-deprived cells from a B-lymphoma cell line with MYC-induced activation, acetyl-CoA is solely generated through glutamine catabolism. Hence, in this context, glutamine-dependent TCA cycle function induces cellular survival and increased growth in a nutrient-poor microenvironment [246]. In addition, in AML cell lines, inhibition of glycolysis does not affect TCA cycle activity, suggesting that AML cells might utilise acetyl-CoA as an alternate energy source to glucose [247] (Figure 3).

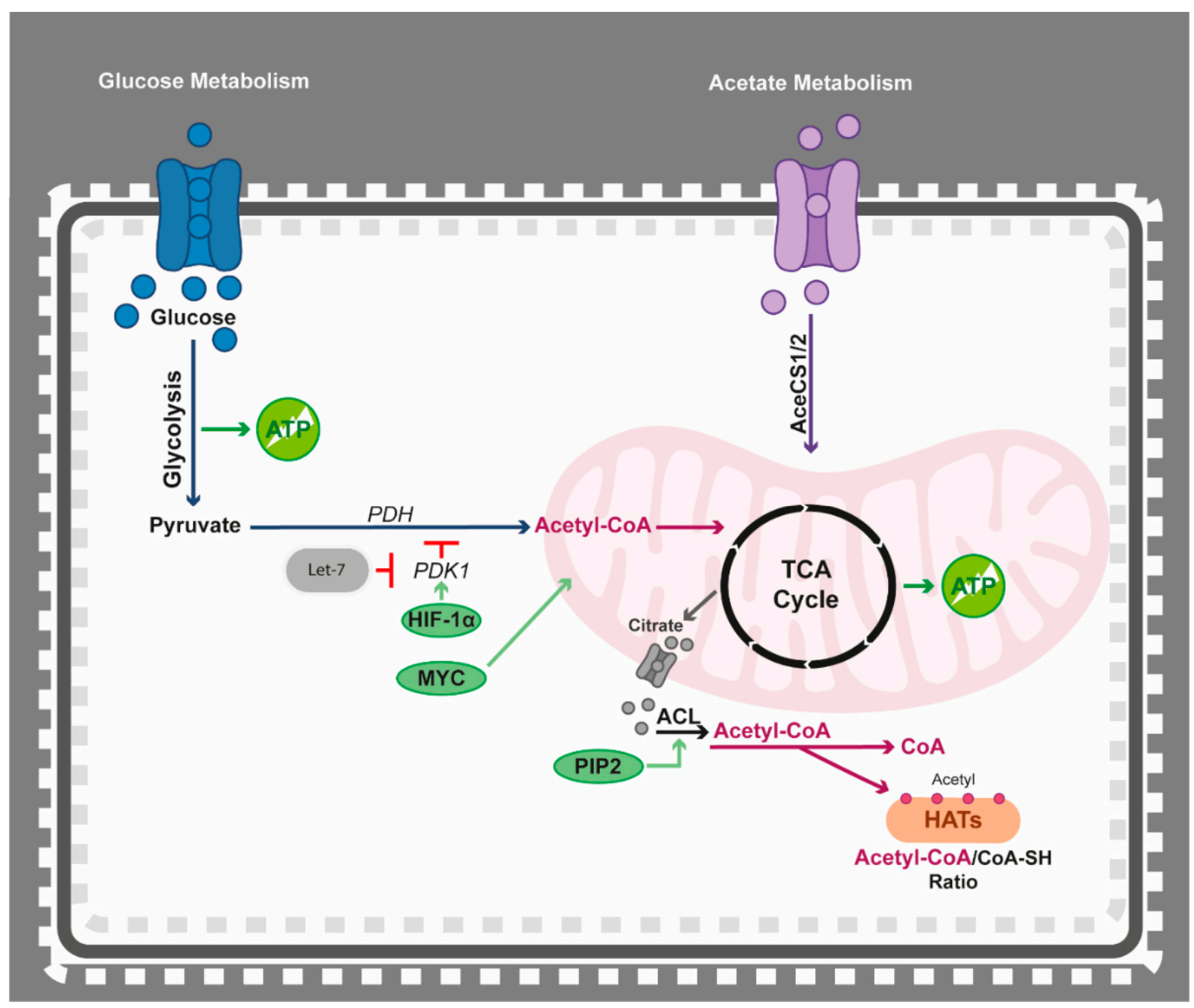

Figure 3. Increased glucose uptake affects the accessibility of acetyl-CoA, a key co-factor for the epigenetic regulatory machinery. Increased access to pyruvate promotes inter-mitochondrial availability, which can be used to stimulate TCA cycle activity. As mitochondrial acetyl-CoA cannot easily cross the mitochondrial membrane, active transportation of citrate from the TCA cycle is transported out of the mitochondria and converted to acetyl-CoA by ACL. High levels of acetyl-CoA promote HATs activity and can be regulated by HIF- $1 \alpha$ by promoting activation of PDK1, which inhibits PDHs, limiting acetyl-CoA accumulation in the mitochondria. Red lines indicate inhibitory effect, while all other arrows indicate enzymatic activity. HIF-1 $\alpha$, hypoxia-inducible factor 1-alpha; AceCS, acetyl-CoA synthetase; PIP2, phosphatidylinositol-4,5bisphosphate; HATs, histone acetyltransferases; PDH, pyruvate dehydrogenase E1; PDK, pyruvate dehydrogenase kinase 1; and ACL, ATP-citrate lyase. 
One additional metabolic pathway often dysregulated in haematological malignancies is the TCA cycle. This is caused by mutations in IDH1/2 leading to disruption of $\alpha-\mathrm{KG}$ production in favour of biosynthesis of the oncometabolite 2-HG, which is associated to disease pathogenesis and progression in haematopoietic tumours. In fact, a small molecule inhibitor towards mutant IDH2, enasidenib, has been FDA-approved for refractory AML [248]. In patients with asymptomatic smouldering multiple myeloma (SMM), high levels of 2-HG are suggested to be associated with a higher risk of progression into symptomatic MM [249]. Production of $\alpha-K G$ can also be achieved via the increased uptake of glutamine that, in a second step, can be converted to $\alpha-K G$ by glutamate dehydrogenase (GLUD) (Figure 4). Depicting the importance of this metabolite, MM and ALL cell lines under depletion of glutamine have been shown to display increased sensitivity to inhibition of the antiapoptotic BCL-2. Conversely, supplementing these cell lines with an excess of $\alpha-K G$ limited the proapoptotic effects of conventional treatments $[250,251]$. Furthermore, 2-HG was recently shown to exhibit antitumour activity potentially via reducing glycolysis in wild-type IDH AML cells [252,253]. Additionally, disruption of the TCA cycle may be induced by the overexpression of fumarate hydratase (FH) and has been shown in AML, suggesting active fumarate/succinate catalysation [254]. Mutations in any of the succinate dehydrogenase subunits (SDHA, SDHB, SDHC, and SDHD) can cause accumulation of succinate [255]. In fact, in paediatric T-ALL and CLL, mutations in the subunit SDHB have been shown to have a potential role in preadaptation to hypoxia [256,257].

Yet another crucial cellular metabolic circuit in cancer is the methionine metabolism, which comprises of the methionine cycle, the methionine salvage, homocysteine degradation, and the folate pathways (Figure 5). Interestingly, monocytic leukaemia cells cannot proliferate in a methionine-deprived environment, despite having access to high levels of homocysteine, which is a feature of these tumour cells in large contrast to normal cells [258]. Targeting the methionine metabolism directly in MLL-rearranged leukaemias via methionine deprivation leads to induction of apoptosis, further proving the importance of this metabolite in haematopoietic tumours [259]. In MM, as well as other haematological cancers, overexpression of the L-type amino acid transporter 1 (LAT1) $[260,261]$ results in the increased uptake of methionine [262]. In other haematopoietic tumours, e.g., T-ALL, inhibiting LAT1 has provided insight into the need for haematological cancer cells to reprogramme the cellular metabolism in order to meet their increased nutrient requirements [261]. Overexpression of 3-phosphoglycerate dehydrogenase (PHGDH) is an alternate route to meet the increased need for upregulated methionine (Figure 5). PHGDH is a rate-limiting enzyme in the glycine-serine synthesis pathway and utilizes glycolysis intermediates as donors for remethylation of tetrahydrofolate within the folate cycle. Tetrahydrofolate remethylation within the folate pathway contributes to the recycling of homocysteine to methionine [263]. Combinatorial treatment utilising a PHGDH inhibitor in MM has been shown to resensitise cancer cells to bortezomib [264]. In addition, depleting serine in leukaemic cells in combination with PHGDH inhibition resulted in reduced cell growth [265]. In Burkitt's lymphoma, PHGDH and PSAT1 are upregulated by the action of MYC/ATF4, therefore, increasing the activity of the glycine-serine pathway [266]. Furthermore, inhibition of the folate metabolism, with molecules called antifolates, is a common therapeutic strategy in a wide range of haematological malignancies [267].

All of the above-described cellular metabolic pathways, further to playing crucial roles, are also tightly associated to epigenetic gene regulation in haematological cancers. 


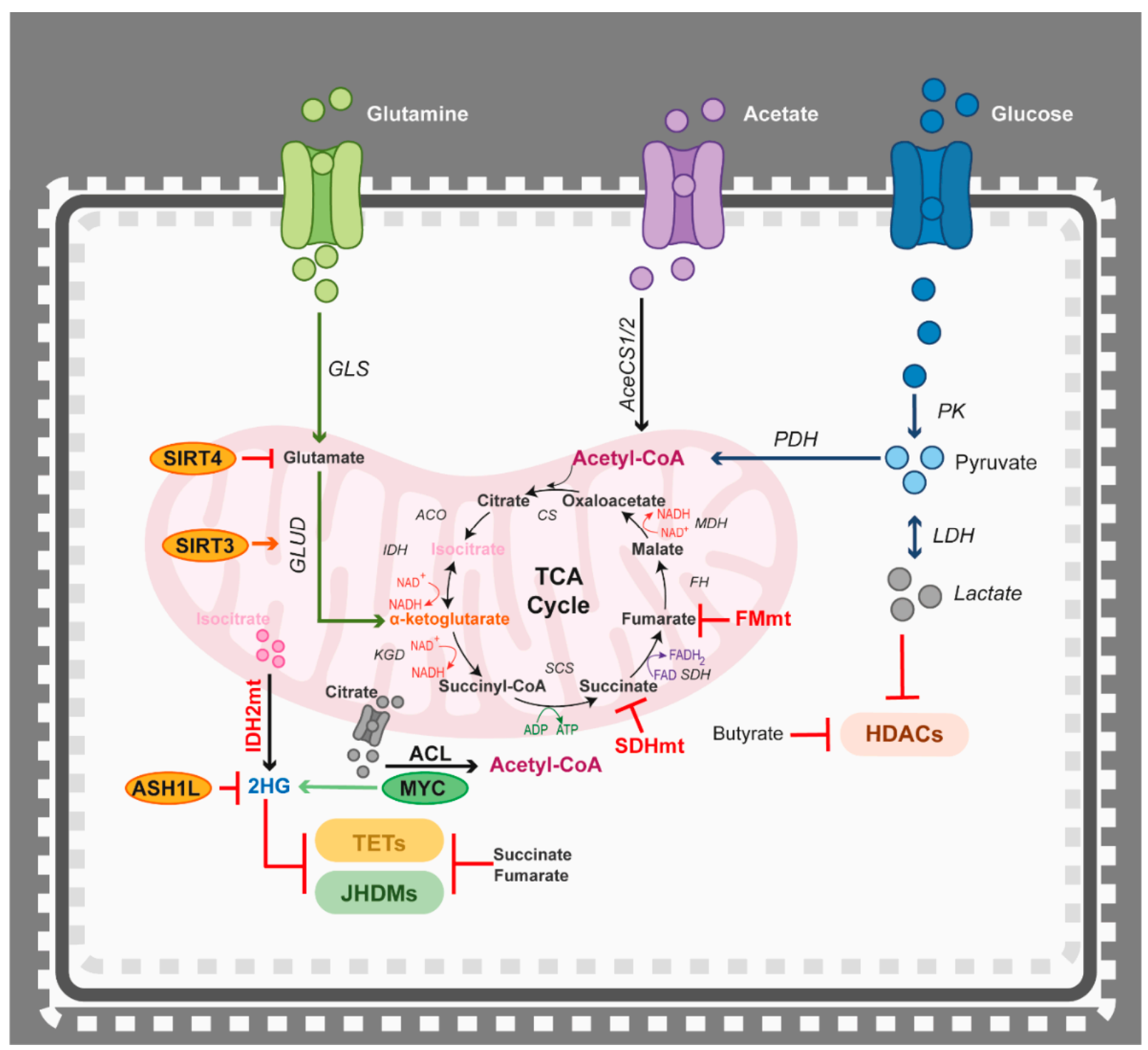

Figure 4. The TCA cycle is highly regulated by the access to glucose, glutamate, and acetate. Increased availability of glucose produces acetyl-CoA that can be utilised within the TCA cycle to produce citrate to be transported out of the mitochondria for acetylation conversion. In addition, increased access to glutamate allows for the TCA cycle metabolite $\alpha$-ketoglutarate to accumulate, thus driving ATP production. Impairment within the TCA cycle genes has a severe impact on the epigenetic regulation. IDH2 mutation promotes accumulation of 2HG, which inhibits the TETs and JHDMs, in addition to increased levels of fumarate and succinate due to mutations in SDH or FM. Increased lactate production from pyruvate results in reduction in $\mathrm{NAD}^{+} / \mathrm{NADH}$ ratios, which inhibits SIRTs and HDACs function. Red lines indicate inhibitory effect and green arrows indicate a promoting effect, while all other arrows indicate enzymatic activity. GLS, glutaminase; GLUD, glutamate dehydrogenase; SIRT3, sirtuin 3; SIRT4, sirtuin 4; ASH1L, ASH1-like histone lysine methyltransferase; ACO, aconitase; IDH, isocitrate dehydrogenase; IDH2mt, isocitrate dehydrogenase 2 mutant; KGD, $\alpha$-ketoglutarate dehydrogenase; SCS, succinyl-CoA synthase; SDHmt, succinate dehydrogenase mutant; SDH, succinate dehydrogenase; FH, fumarate hydratase; FMmt, fumarate hydratase mutant; CS, citrate synthase; PK, pyruvate kinase; PDH, pyruvate dehydrogenase E1; LDH, lactate dehydrogenase; HDAC, histone deacetylase; AceCS, acetyl-CoA synthetase; ACL, ATP-citrate lyase; 2HG, (R)-2-hydroxyglutarate; TET, Tet methylcytosine dioxygenase; and JHDM, lysine demethylase. 


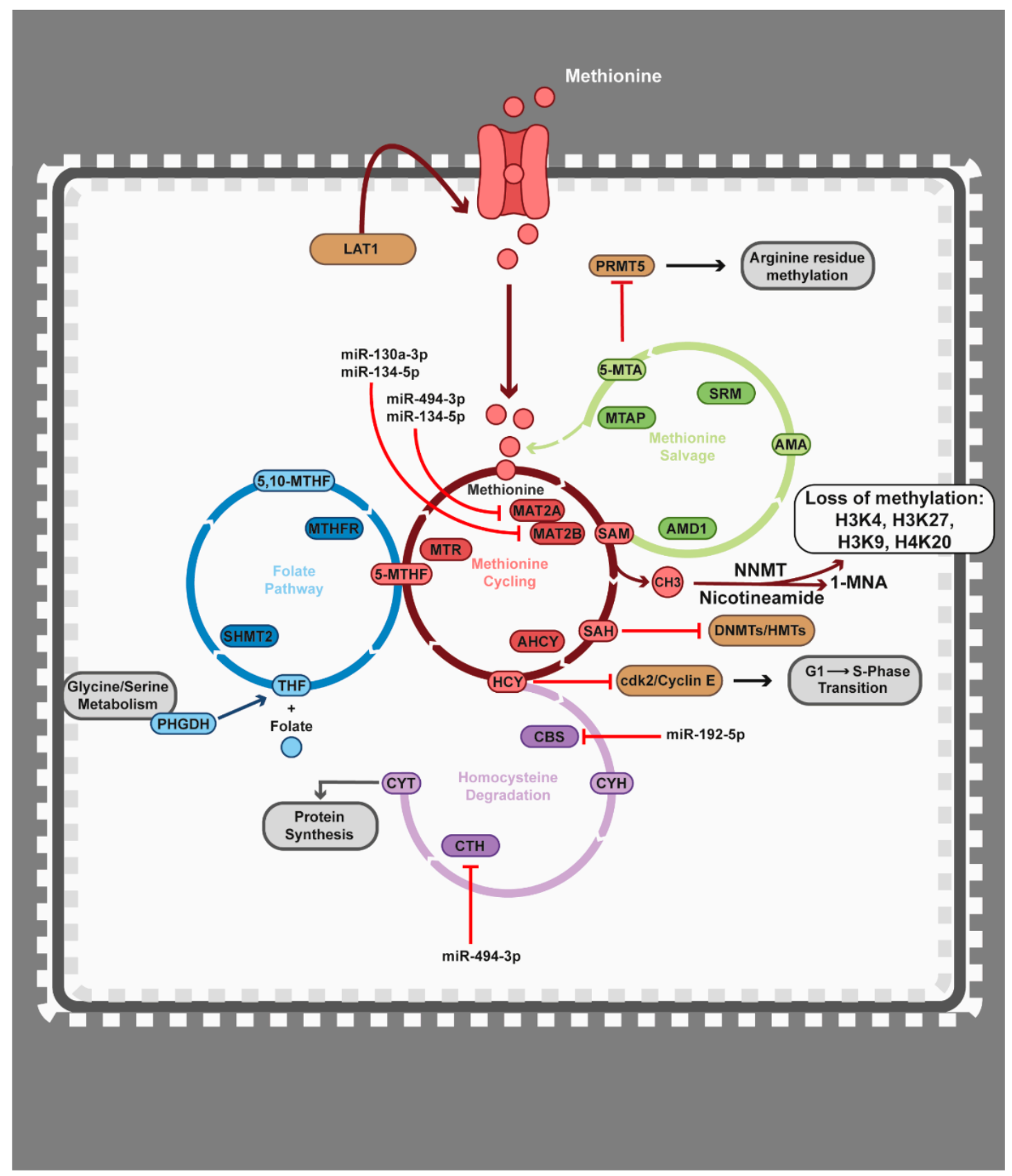

Figure 5. Representative illustration of the interconnection between methionine metabolism, the metabolome, and the epigenetic regulatory network. The access to methyl groups regulates the activity of histone and DNA methyltransferases. Accumulation of SAM promotes DNMTs/HMTs, while accumulation of SAH represses DNMTs/HMTs activity. A proposed miRNA-mediated silencing mechanism within methionine metabolism causes homocysteine accumulation, prevents normal cell cycle transition, and induces apoptosis in haematological malignancies. Red lines indicate inhibitory effect. 5,10-MTHF, 5, 10-methylenetetrahydrofolate; MTHFR, methylenetetrahydrofolate reductase; 5-MTHF, 5-methyltetrahydrofolic acid; MTR, 5-methyltetrahydrofolate-homocysteinemethyltransferase; THF, tetrahydrofolic acid; PHGDH, phosphoglycerate dehydrogenase; SHMT2, serinehydromethyltransferase 2; MAT2A, methionine adenosyltransferase 2A; MAT2B, methionine adenosyltransferase 2B; SAM, S-adenosylmethionine; SAH, S-adenosylhomocysteine; AHYCY, adenosylhomocysteinase; HCY, homocysteine; LAT1, L-type amino-acid transporter 1; CBS, cystathionine beta-synthase; CTH, cystathionine gammalyse; CYH, cystathionine; CYT, cysteine; cdk2, cycline dependent kinase 2; NNMT, nicotinamide N-methyltranferase; 1-MNA, 1-methylnicotinamide; DNMTs, DNA methyltransferases; HMTs, histone methyltransferases; AMD1, adenosylmethionine decarboxylase 1; AMA, S-adenosylmethinineamine; SRM, spermidine synthase; 5-MTA, 5' -methylthioadenosine; MTAP, methylthioadenosine phosphorylase; and PRMT5, protein arginine methyltransferase 5. 


\section{The Teamwork between Epigenetics and Metabolism in Haematological Malignancies}

Metabolic reprogramming is key for the maintenance of viability, not only by altering nutrient influx and funnelling these nutrients into biosynthetic pathways, but also by controlling gene activity. In fact, metabolism and epigenetics are interdependent mechanisms, whereby epigenetic enzymes, on one hand, utilise metabolites as cofactors, and, in turn, have the capacity to regulate the expression of metabolic enzymes [241,268]. Several pathways are vital for global epigenetic reprogramming, such as glucose transportation, glycolysis, TCA cycle, and glutaminolysis, as well as the metabolism of lactate, methionine, lipids, and amino acids $[269,270]$. This interplay certainly provides a rationale for studies assessing the link between, e.g., sensitivity to epigenetic therapies and different metabolic pathways. Moreover, given the profoundly altered epigenetic system of haematopoietic tumours, as described above, examining the accompanying changes in the metabolome of these tumours has recently spurred large attention.

\subsection{Epigenetics Teams up with the Metabolic Switch from Oxidative Phosphorylation to Glycolysis}

Management of the glycolytic switch by different layers of epigenetic regulation has been observed in many haematological cancers [231,249,271-275]. In the first step of glycolysis, glucose is converted by hexokinase (HK) to glucose-6-phosphate, while pyruvate kinase isoform M2 (PKM2) catalyses the final dephosphorylation of phosphoenolpyruvate to pyruvate (Figure 2). Interestingly, upregulation of HK2 has been suggested to contribute to drug resistance in various haematological malignancies [276-278]. In paediatric AML and CML, HK2 has been shown to be directly targeted by miR-125a and miR-202, in this way disrupting glycolysis and, thus, overcoming chemoresistance [201,279]. Other miRNAs have also been demonstrated to regulate HK2, e.g., high expression of miR-98 has been associated with a good prognosis in AML patients [280,281]. In addition, in immunodeficient mice models of MM, Hk2 knockout triggers resensitisation to proteasome inhibition, whereas PKM2 has been described to block myeloid cell differentiation [282]. Furthermore, studies show that inactivation of HK2 and PKM2 induces apoptosis and inhibition of glycolysis in myeloid leukaemic cells, as well as in MM [276-278]. In MM, histone deacetylase inhibitors have been shown to inhibit glucose utilization through downregulation of GLUT1 and inhibition of HK enzymatic activity [283]. In paediatric anaplastic large-cell lymphoma, the constitutive activation of the anaplastic lymphoma kinase (ALK) due to the recurrent $\mathrm{t}(2 ; 5)$ (p23;q35) translocation phosphorylates PKM2, thus promoting the switch to glycolysis [284]. In CML, miR-140-5p acts as a tumour suppressor by targeting SIX1, a positive regulator of PKM2 [285]. Prior studies have demonstrated that miR-124 targets the PKM2 splicing proteins, thereby inhibiting the glycolytic metabolic rate (Figure 2) [286]. MiR-124 displays tumour-specific hypermethylation, rendering its expression silenced in ALL [287] and NHL [288].

Several regulatory mechanisms operate in glucose uptake and glycolysis, one of which includes the targeting of signalling pathways by miRNAs (Figure 2). In haematological cancers, miR-223 has been associated with both blockage of PI3K signalling and the prevention of differentiation of myeloid precursors [289]. Downstream of PI3K/AKT/mTOR signalling is HIF-1 $\alpha$, a crucial regulator in the shift from oxidative phosphorylation to glycolysis, as described above. In MM, miR-199a-5p has been nominated as a master regulator of HIF-1 $\alpha$ and has been shown to be downregulated as a result of dysregulated AKT pathway [202,290], whereas miR-411-3p has been shown to inhibit HIF-1 $\alpha$, thus leading to a reduced cell proliferation [291]. In CLL, miR-92-1 targets VHL, a known tumour suppressor regulating HIF-1 $\alpha$ [292]. Additional molecular mechanisms underlying the HIF-1 $\alpha$-mediated metabolic switch to glycolysis have been suggested, including DNMT3A-mediated promoter methylation. DNMT3A may silence the expression of the PI3K suppressors PTEN [249,293-295], LKB1 [270], and VHL [49,296,297], as well as the HIF-1 $\alpha$ suppressor PHD3 [298], all in favour of PI3K activation (Figure 2). In AML, underexpression of miR-193a, a DNMT3A-targeting miRNA, triggers PTEN expression and 
results in PI3K cascade activation [299]. Taken together, these data suggest that dysregulation of DNMT3A may be an important regulator in promoting the metabolic shift from oxidative phosphorylation to glycolysis. The lysine-specific demethylase 3A (KDM3A), which demethylates $\mathrm{H} 3 \mathrm{~K} 9$, has also been described to stimulate the upregulation of proglycolytic genes in the glycolysis pathway. In MM, under hypoxic conditions the KDM3A is overexpressed in patient samples [300], which increases the expression of long noncoding RNA MALAT1 and contributes to accumulation of HIF- $1 \alpha$ and upregulation of glycolysis-promoting genes [203] (Figure 2).

As an alternative to meet the increased energy requirement of a highly proliferative cancer cell is to increase the glucose uptake - expression, or loss of expression of miRNAs may, in some cases, indirectly regulate the active transport of glucose by targeting GLUT1 (Figure 2). For example, the loss of miR-144 and miR-218 has been associated with increased glucose uptake and enhanced aerobic metabolism [301,302]. Interestingly, miR-144 expression has been shown to be reduced in both peripheral blood and bone marrow samples of AML patients [303]. In alignment with this, miR-144 has been demonstrated to inhibit proliferative capability in MM [304,305], and miR-218 expression has also been demonstrated to be decreased in MM compared to normal cells [306]. In addition, upregulation of miR-144 leads to limited cell migration capacity in AML/ETO ${ }^{+}$leukaemic cells [304,307]. The expression of miR-340, which is also predicted to target GLUT1, is epigenetically silenced by DNA methylation in MM [286,308], and low expression of miR-340 has been previously associated with a poor outcome in AML [309]. There are several examples of other miRNAs described as important regulators of GLUT1 in haematological cancers. In CML, loss of miR-150 expression has been shown to cause drug resistance [310,311], while it is downregulated in AML and is a critical tumour suppressor in MLL-fusion-induced leukaemogenesis [312]. MiR-532-3p has been previously associated with downregulation of GLUT1, which is accompanied by reduced proliferation in lymphoma cells [313]. Interestingly, miR-125b in T-ALL indirectly reprogrammes the metabolism by repressing the NF-к $\beta$ suppressor A20, which promotes the glycolytic switch, possibly via subsequent upregulation of GLUT1 expression [314]. In CLL, the expression of miR-125b has been found to be reduced in both aggressive and indolent cases and miR-125b overexpression led to changes in glucose, glutathione, lipid, and glycerolipid metabolism [315]. MiR-19a/b has been described to regulate GLUT1 $[316,317]$ and is associated with poor prognosis in MM [318]. In paediatric leukaemia cells and leukaemia cell lines, expression of miR-34b is often suppressed by DNA methylation, which is suggested to affect patient response to early treatments [319]. Gain-of-function studies in MM and paediatric AML have shown that expression of miR-489 and miR-34b inhibits aerobic glycolysis by reducing glucose uptake, lactate, and ATP production by directly targeting GLUT1. In addition, upregulation of both miRNAs limited cell proliferation and induced apoptosis [320,321]. Similarly, downregulation of miR-489 leads to LDHA overexpression in MM [232]. In the second step of glucose metabolism, previous studies in leukaemia have described miR-15a and miR-16-1 as targeting the aldolase A (ALDOA), which converts fructose-1,6-bisphosphate to glyceraldehyde 3-phosphate and dihydroxyacetone phosphate in the glycolysis pathway [322] (Figure 2). Connecting glucose uptake indirectly to activation of epigenetic enzymes with dual activity, in AML, LSD1 stabilises the transcription factor GATA1 on protein level and epigenetically silences the GATA1 negative regulator $\mathrm{C} / \mathrm{EBP} \alpha$, thus promoting glucose metabolism [323]. In haematological malignancies, e.g., AML, MDS, and CML, LSD1 contributes to leukaemogenesis [324].

In contrast, as leukaemia stem cells in de novo AML samples are highly dependent on amino acid metabolism to drive oxidative phosphorylation, combining BCL-2 inhibitor venetoclax with DNMT inhibitor azacytidine in these cells was shown to reduce oxidative phosphorylation by decreasing the usage of the amino acid metabolic pathway [233,234]. However, venetoclax/azacytidine combinatorial treatment failed to achieve the same effect in refractory/relapse patients, possibly due to the activation of nicotinamide metabolism, which likely provides an alternative source of $\mathrm{NAD}^{+}$for amino acid metabolism, but also 
fatty acid oxidation, both of which are needed to drive oxidative phosphorylation [234,325] (Figure 2).

The activation of PDK1 by HIF- $1 \alpha$ results in inhibition of PDH, reduced production of substrates to the TCA cycle and promotion of glycolysis. As previously mentioned, PDKs have important roles in haematological malignancies [217-219], while regulatory miRNAs of PDK1 have been implicated in MM and AML [326,327]. For example, let-7 is a direct inhibitor of PDK1, which, in turn, inhibits glycolysis in favour of oxidative phosphorylation through PDH activity [328] (Figure 3). PDH has also been suggested to be a direct target of miRNAs, such as miR-26a, miR-146b, and miR-370 [329-331]. Previous studies in haematological malignancies have shown that these miRNAs possess tumour suppressive functions [332-335].

As an alternative carbon source, tumour cells may use glutamine, which can be transported into the cell by the solute carrier family 1 member 5 (SLC1A5). Studies have shown that miR-137 and miR-122 directly inhibit SLC1A5, resulting in downregulation of glutamine metabolism [336] (Figure 2). Interestingly, miR-137 has been demonstrated to be epigenetically silenced by promoter hypermethylation in MM and ALL cells [337,338]. In addition, low expression of miR-122 has been associated with poor prognosis in AML [339]. $\mathrm{MiR}-23 \mathrm{a} / \mathrm{b}$ directly regulates glutaminase (GLS), the enzyme responsible for the conversion of glutamine to glutamate, needed for the generation of $\alpha$-KG (Figure 2). In B-cell lymphoma, MYC-mediated suppression of miR-23a/b results in increased glutamine metabolism [340]. Interestingly, overexpression of miR-23a causes a reduction in GLS expression and promotes cell death in leukaemic cells [340]. Sirtuins (SIRTs), or HDACs class III, have also been shown to have relevant implications for the increased need for glycolysis, glutaminolysis, and lipid metabolism [341]. SIRTs are dependent on the availability of $\mathrm{NAD}^{+}$and the $\mathrm{NAD}^{+} / \mathrm{NADH}$ ratio is highly connected to energy output (Figure 2). Lactate conversion to pyruvate requires the reduction in $\mathrm{NAD}^{+}$to $\mathrm{NADH}$, while the reverse reaction requires $\mathrm{NADH}$, which results in $\mathrm{NAD}^{+}$increase. As such, the $\mathrm{NAD}^{+} / \mathrm{NADH}$ ratio is closely related to the availability of pyruvate and lactate, as well as the enzymatic activity of LDHA [342]. When cellular energy is high, the NAD ${ }^{+} / \mathrm{NADH}$ ratio drops and a genome-wide nonacetylated state is assumed [343]. SIRT6 causes deacetylation of H3K9 and histone $\mathrm{H} 4$ lysine 56 (H4K56), as well as non-histone proteins, and its activity has also been described to alter cellular glucose metabolism by deacetylating PGC- $1 \alpha$, thus promoting increased gluconeogenesis [344].

\subsection{Epigenetics Teams up with Acetyl-CoA}

Acetyl groups are essential for cellular substrate-dependent mechanisms, such as the epigenetic action of HATs, exemplifying that not only does the epigenome regulate the metabolome, but the converse is also true. Access to high levels of acetyl-CoA promotes cellular growth, lipid synthesis, and histone acetylation. In the cytoplasm, citrate is used to produce acetyl-CoA with the help of ACL (Figure 3) [241]. ACL activity correlates with increased histone acetylation in cancer cells $[345,346]$ and ACL knockdown decreases histone acetylation and disrupts the expression of glycolysis-related genes [346]. The PI3K pathway is commonly dysregulated in cancer due to mutations in PI3K/PTEN and/or upstream activators, such as the RAS family of proteins. When activated, PI3K catalyses the conversion of phosphatidylinositol-4,5-bisphosphate (PIP2) into phosphatidylinositol3,4,5-triphosphate (PIP3), the messenger molecule that signals activation to downstream effectors, including AKT (Figure 3). In AML, PIP2 binding to ACL enhances its activity, whereas inhibitors against PI3K reduce ACL activity and acetyl-CoA availability, resulting in blockage of H3K9 acetylation [347]. Upon active HIF-1 signalling, less pyruvate is available for TCA-mediated acetyl-CoA production and the predominant source of acetylCoA is the catalysation of acetate by AceCS, as described above [243,244] (Figure 3). In $\mathrm{MM}$, AceCS2 contributes to disease pathogenesis via increased acetylation and stabilisation of the known oncogene IRF4 [245]. 
In summary, due to the vital role of the deposition of acetyl groups on key residues within the chromatin landscape, many of the enzymes regulating the availability of acetylCoA are dysregulated in haematological malignancies to maintain a favourable tumour transcriptional environment.

\subsection{Epigenetics Teams up with the Tricarboxylic Acid (TCA) Cycle}

Similar to acetyl-CoA, the TCA intermediate metabolite $\alpha-K G$ acts as a cofactor for a number of epigenetic enzymes. These include the DNA demethylating enzymes TET1/2, as well as the members of the Jumonji-domain histone demethylase (JHDM) family. Mutations in IDH1/2 cause disruption of $\alpha-\mathrm{KG}$ production and synthesis of the oncometabolite 2HG. Linking the activity of 2-HG to epigenetic regulation, prior studies have shown that 2-HG has an inhibitory effect on the $\alpha$-KG-dependent TET1/2 and JHDM2A/KDM3A enzymes [72,75] (Figure 4). As mentioned in the section above, approximately 20\% of AML and T-cell lymphoma patients carry mutations in the IDH gene, thus resulting in disease-specific histone and DNA hypermethylation signatures [69,73,348]. Enasidenib is an FDA-approved small molecule inhibitor of mutant IDH2 that has, in experimental mouse xenograft models of AML, proven to reduce serum levels of 2-HG and decrease DNA and histone methylation [248]. Loss of the histone lysine methyltransferase ASH1L has been described to lead to upregulation of HOXA9 in AML, which co-operates with mutant IDH2 in accelerating leukaemogenesis [349]. In addition, a decrease in $\alpha-\mathrm{KG}$ has been shown to cause hypermethylation in AML samples, similar to what is observed in AML patients carrying IDH2 mutations [350].

Lysine demethylases of the JHDM family, such as the TET proteins, are dependent on $\alpha$-KG from the TCA cycle as a cofactor and are inhibited by succinate and fumarate accumulation [351] (Figure 4). In cancer, alterations in both FH and succinate dehydrogenase $(\mathrm{SDH})$ can lead to disruption in the $\alpha-\mathrm{KG} /$ fumarate/succinate balance, causing an inhibitory effect on TET and JHDM activity and leading to aberrant DNA and histone methylation [351-353]. In DLBCL, impairment of the SIRT3 histone deacetylase has significant negative effects on glutaminolysis, which fuels the TCA cycle [354]. Glutamate is converted to $\alpha-K G$ by GLUD to release stored energy by oxidation through the TCA cycle. Deacetylation of GLUD by SIRT3 is vital for GLUD enzymatic activity, and, thus, is critical for glutamate-dependent DLBCL cells [354]. SIRT4 expression has been detected when treating primary AML cells with histone deacetylase inhibitors. However, SIRT4 has an inhibitory effect on glutamine metabolism, serving as a metabolic block by repressing glutamine uptake into the TCA cycle, which, in turn, contributes to cell cycle G1 arrest [355]. This process is made possible by the repression of mitochondrial GLUD [356] (Figure 2). Interestingly, deacetylation capacity is highly dependent on and regulated by metabolic activity and rate-limiting macromolecules. In fact, deacetylation by HDACs can be metabolically antagonized by butyrate. In a murine model of lymphoma, high intake of butyrate through extensive fibre consumption has been shown to reduce cancer cell growth in combination with dose-dependent induction of apoptosis and histone deacetylation [357]. Furthermore, accumulation of lactate has also been shown to reduce HDAC activity [358] (Figure 4).

\subsection{Epigenetics Teams up with the Methionine Cycle}

DNMTs and HMTs are highly regulated by access to methyl groups in the form of S-adenosyl-methionine (SAM), which is derived from methionine metabolism (Figure 5). In the first step, the methionine adenosyltransferase 2A/B (MAT2A/MAT2B) complex converts methionine to SAM. This process generates the byproduct S-adenosyl-homocysteine (SAH), which, in a negative feedback loop, strongly inhibits DNMTs and HMTs [270]. In the second step, SAH is converted to homocysteine (HCY) by adenosyl homocysteinase (AHCY). Interestingly, introducing a competitive inhibitor to AHCY in combination with DNMT inhibition results in the reactivation of potent tumour suppressor genes in AML cells [359]. In the third step, HCY can either be degraded by cystathionine gamma-lyase 
(CTH) and cystathionine beta synthase (CBS) enzymes, or become remethylated by the donation of a methyl group from 5-methyltetrahydrofolic acid (5-MTHF), which is catalysed by the 5-methylhydrofolate-homocysteine methyltransferase (MTR) enzyme in the folate pathway $[360,361]$ (Figure 5). Increased cellular access to SAM alone has been demonstrated to cause DNA hypermethylation [362]. In MLL-rearranged leukaemia methionine deprivation leads to an overall loss of cellular methylation potential and induction of apoptosis [259]. As mentioned above, overexpression of PHGDH is an alternate route to meet the increased need for upregulated methylation. In Burkitt's lymphoma, chemical inhibition of PHGDH resulted in decreased DNA and histone methylation, reactivation of tumour suppressor genes, and decreased proliferation [266].

SAM can also be consumed during the conversion of nicotinamide to 1-methylnicotinamide (1-MNA) by nicotinamide N-methyltransferase (NNMT) (Figure 5). As a master regulator of SAM accessibility, overexpression of NNMT causes rapid SAM depletion and limits the availability of methyl donors to DNMTs and HMTs. In addition, NNMT overexpression contributes to maintaining the pluripotency of embryonic stem cells [363]. Cells overexpressing NNMT show a complete depletion of H3K4, H3K9, H3K27, and H4K20 methylation, resulting in dysregulation of key signalling pathways and allowing for an undifferentiated pluripotent phenotype [364]. In addition, polymorphisms in NNMT have been associated with a prognostic risk of developing paediatric ALL [365].

The link between methionine metabolism and drug response was recently demonstrated by us in MM [366]. In this study, we utilised cellular metabolic profiling to determine the response to an epigenetic-targeted intervention. This metabolomics profiling revealed that inhibition of the HMT EZH2 impaired the methionine metabolism pathways by downregulation of $M A T 2 A, M A T 2 B, C B S$, and $C T H$. This effect was mediated by the reactivation of miR-494-3p, miR-130a-3p, miR-134-5p, and miR-192-5p. Interestingly, these miRNAs have previously been connected with drug sensitivity, response, and prognosis in other haematological cancers [367-371]. The microRNA-mediated gene downregulation was accompanied by the accumulation of HCY and 5-MTHF in the methionine cycling pathway, and 5-methylthioadenosine (5-MTA) in the methionine salvage pathway. 5-MTA acts as a competitive inhibitor of the arginine methyltransferase PRMT5 (Figure 5), which has been shown to promote cell cycle progression in combination with PI3K-AKT activation in DLBCL [372]. Furthermore, methylthioadenosine phosphorylase (MTAP) loss in T-ALL has been demonstrated as a therapeutic vulnerability due to limiting PRMT5 activity [373] (Figure 5). These results suggest that metabolic profiling should be considered a significant and relevant tool to determine cell sensitivity to epigenetic treatments.

\section{Conclusions and Future Directions}

Genetic and gene expression profiling are readily used to study cancer biology, disease progression, and response to treatment. Whole-genome epigenomic studies are closely catching up to also being widely used, as epigenetic gene regulation by DNA methylation, miRNA-associated gene repression, and histone modifications is now being recognised as equally important in the onset and progression of the disease. Needless to say, the tightly intertwined collaboration between the cellular genetic background, the epigenetic machineries in play, and the gene expression output are becoming a central part in understanding disease. However, the mechanisms by which the metabolism regulates gene expression are often neglected and ill-appreciated, although the methods to study whole-cell metabolites, such as liquid chromatography-mass spectrometry, have existed for decades. Furthermore, although an integrated understanding of the epigenetic and metabolic interplay in cancer is far from complete, it is well-established that the cellular metabolic status both influences and is influenced by the epigenome. Firstly, the accessibility to co-factors needed by epigenetic enzymes is commonly altered due to reprogramming of the cellular metabolism. Hence, metabolic rewiring in cancer has the potential to hijack the epigenetic machinery in order to produce a gene expression profile that favours increased proliferation. Secondly, epigenetic changes regulate the expression of key enzymes in metabolic pathways, thereby 
modulating the access to key biomolecules. This interdependency may disclose previously unrecognised therapeutic vulnerabilities that, alone or in combinatorial regimens, could open for yet novel therapeutic approaches for combatting cancer.

Dysregulation of the epigenetic machinery is well-documented in haematological cancers, in some cases, also as a driver event, e.g., mutated IDH1/2 in AML. Two main characteristics of epigenetic regulation make it an exceptional target for therapeutic intervention. On one hand, unlike genetic defects, all epigenetic mechanisms are reversible and, therefore, amenable for treatment. On the other hand, epigenetics acts at the genome scale by regulating multiple loci at the same time, and thus the targeting of individual epigenetic enzymes has an effect on a multitude of genes, reducing the likelihood of developing resistance. Reflecting this, epigenetic treatments are now part of the standard of care for several haematological malignancies; DNMT inhibitors are currently used for the treatment of AML and MDS, and HDACs are FDA-approved for the treatment of MM, CTCL, and peripheral T-cell lymphoma [374]. Additionally, at the time that this review was written, there were 83 registered clinical studies for epigenetic inhibitors in cancer (https:/ / clinicaltrials.gov/; accessed on 6 July 2021). Likewise, several drugs directed towards the abnormal cancer metabolism are currently used in clinical practice. In fact, two of the first FDA-approved pharmacological treatments for cancer, i.e., leucovorin and methotrexate, interfere with folate metabolism [375], and more metabolism-targeting drugs are at different phases of clinical validation [376].

To fully utilise the potential of the interplay between metabolism and epigenetic modulators, future clinical trials in these and other areas should incorporate the analysis of biomarkers to unravel not only alterations to the transcriptome, but also to the metabolome, thus allowing for the stratification of patients that might benefit from targeted treatments and providing a tool for the monitoring of the response over time. This is facilitated by the fact that metabolites can be readily detected by using noninvasive methods in, for instance, plasma. Exemplifying this, the recent study from our research group provides new insights into the metabolic response to targeted epigenetic treatment in MM and suggests that metabolic profiles have potential as biomarkers for the response to EZH2 inhibition in MM. Furthermore, given the extensive association between epigenetics and metabolism, combination approaches involving dual inhibition of epigenetic and metabolic regulators may certainly hold promise for tumour growth inhibition.

Funding: H.J.-W. was funded by the Swedish Cancer Society (CAN 2016/458, 200727 PjVSF), the Swedish Childhood Cancer Fund (PR2020-0043) and the Swedish Research Council (K2019-64X20102-13-3/KDB 1335/17). A.L. was funded by the Swedish Childhood Cancer Fund (TJ2015-0064 and PR2016-0120).

Acknowledgments: Figures are created with BioRender.com (Accessed on 25 May 2021). We are grateful to Tiarne van de Walle for critically reading the manuscript.

Conflicts of Interest: The authors have no conflict of interest to declare.

\section{References}

1. Bird, A. DNA methylation patterns and epigenetic memory. Genes Dev. 2002, 16, 6-21. [CrossRef] [PubMed]

2. Okano, M.; Bell, D.W.; Haber, D.A.; Li, E. DNA Methyltransferases Dnmt3a and Dnmt3b Are Essential for De Novo Methylation and Mammalian Development. Cell 1999, 99, 247-257. [CrossRef]

3. Robert, M.-F.; Morin, S.; Beaulieu, N.; Gauthier, F.; Chute, I.C.; Barsalou, A.; MacLeod, A.R. DNMT1 is required to maintain CpG methylation and aberrant gene silencing in human cancer cells. Nat. Genet. 2002, 33, 61-65. [CrossRef] [PubMed]

4. Saxonov, S.; Berg, P.; Brutlag, D.L. A genome-wide analysis of CpG dinucleotides in the human genome distinguishes two distinct classes of promoters. Proc. Natl. Acad. Sci. USA 2006, 103, 1412-1417. [CrossRef]

5. Smith, Z.D.; Meissner, A. DNA methylation: Roles in mammalian development. Nat. Rev. Genet. 2013, 14, 204-220. [CrossRef]

6. Maiti, A.; Drohat, A.C. Thymine DNA Glycosylase Can Rapidly Excise 5-Formylcytosine and 5-Carboxylcytosine: POTENTIAL IMPLICATIONS FOR ACTIVE DEMETHYLATION OF CpG SITES. J. Biol. Chem. 2011, 286, 35334-35338. [CrossRef]

7. Rasmussen, K.D.; Helin, K. Role of TET enzymes in DNA methylation, development, and cancer. Genes Dev. 2016, 30, 733-750. [CrossRef] 
8. Ito, S.; Shen, L.; Dai, Q.; Wu, S.C.; Collins, L.B.; Swenberg, J.A.; He, C.; Zhang, Y. Tet Proteins Can Convert 5-Methylcytosine to 5-Formylcytosine and 5-Carboxylcytosine. Science 2011, 333, 1300-1303. [CrossRef]

9. Tahiliani, M.; Koh, K.P.; Shen, Y.; Pastor, W.A.; Bandukwala, H.; Brudno, Y.; Agarwal, S.; Iyer, L.M.; Liu, D.R.; Aravind, L.; et al. Conversion of 5-Methylcytosine to 5-Hydroxymethylcytosine in Mammalian DNA by MLL Partner TET1. Science 2009, 324, 930-935. [CrossRef]

10. He, Y.-F.; Li, B.-Z.; Li, Z.; Liu, P.; Wang, Y.; Tang, Q.; Ding, J.; Jia, Y.; Chen, Z.; Li, L.; et al. Tet-Mediated Formation of 5-Carboxylcytosine and Its Excision by TDG in Mammalian DNA. Science 2011, 333, 1303-1307. [CrossRef]

11. Ngo, T.T.M.; Yoo, J.; Dai, Q.; Zhang, Q.; He, C.; Aksimentiev, A.; Ha, T. Effects of cytosine modifications on DNA flexibility and nucleosome mechanical stability. Nat. Commun. 2016, 7, 10813. [CrossRef] [PubMed]

12. Hon, G.C.; Song, C.-X.; Du, T.; Jin, F.; Selvaraj, S.; Lee, A.Y.; Yen, C.-A.; Ye, Z.; Mao, S.-Q.; Wang, B.-A.; et al. 5mC Oxidation by Tet2 Modulates Enhancer Activity and Timing of Transcriptome Reprogramming during Differentiation. Mol. Cell 2014, 56, 286-297. [CrossRef]

13. Duy, C.; Teater, M.; Garrett-Bakelman, F.E.; Lee, T.C.; Meydan, C.; Glass, J.L.; Li, M.; Hellmuth, J.C.; Mohammad, H.P.; Smitheman, K.N.; et al. Rational Targeting of Cooperating Layers of the Epigenome Yields Enhanced Therapeutic Efficacy against AML. Cancer Discov. 2019, 9, 872-889. [CrossRef] [PubMed]

14. Li, B.; Carey, M.; Workman, J.L. The Role of Chromatin during Transcription. Cell 2007, 128, 707-719. [CrossRef] [PubMed]

15. Margueron, R.; Reinberg, D. The Polycomb complex PRC2 and its mark in life. Nature 2011, 469, 343-349. [CrossRef]

16. Verdone, L.; Caserta, M.; Di Mauro, E. Role of histone acetylation in the control of gene expression. Biochem. Cell Biol. 2005, 83, 344-353. [CrossRef] [PubMed]

17. Rossetto, D.; Avvakumov, N.; Côté, J. Histone phosphorylation. Epigenetics 2012, 7, 1098-1108. [CrossRef] [PubMed]

18. Wang, Z.; Zang, C.; Rosenfeld, J.A.; Schones, D.E.; Barski, A.; Cuddapah, S.; Cui, K.; Roh, T.-Y.; Peng, W.; Zhang, M.Q.; et al. Combinatorial patterns of histone acetylations and methylations in the human genome. Nat. Genet. 2008, 40, 897-903. [CrossRef]

19. Milne, T.; Briggs, S.D.; Brock, H.W.; Martin, M.E.; Gibbs, D.; Allis, C.; Hess, J.L. MLL Targets SET Domain Methyltransferase Activity to Hox Gene Promoters. Mol. Cell 2002, 10, 1107-1117. [CrossRef]

20. Nakamura, T.; Mori, T.; Tada, S.; Krajewski, W.; Rozovskaia, T.; Wassell, R.; Dubois, G.; Mazo, A.; Croce, C.M.; Canaani, E. ALL-1 Is a Histone Methyltransferase that Assembles a Supercomplex of Proteins Involved in Transcriptional Regulation. Mol. Cell 2002, 10, 1119-1128. [CrossRef]

21. Wu, L.; Lee, S.Y.; Zhou, B.; Nguyen, U.T.; Muir, T.W.; Tan, S.; Dou, Y. ASH2L Regulates Ubiquitylation Signaling to MLL: Trans-Regulation of H3 K4 Methylation in Higher Eukaryotes. Mol. Cell 2013, 49, 1108-1120. [CrossRef] [PubMed]

22. Zhang, Y.; Mittal, A.; Reid, J.; Reich, S.; Gamblin, S.; Wilson, J.R. Evolving Catalytic Properties of the MLL Family SET Domain. Structure 2015, 23, 1921-1933. [CrossRef] [PubMed]

23. Rao, R.; Dou, Y. Hijacked in cancer: The KMT2 (MLL) family of methyltransferases. Nat. Rev. Cancer 2015, 15, 334-346. [CrossRef]

24. Esteller, M. Non-coding RNAs in human disease. Nat. Rev. Genet. 2011, 12, 861-874. [CrossRef] [PubMed]

25. Ha, M.; Kim, V.N. Regulation of microRNA biogenesis. Nat. Rev. Mol. Cell Biol. 2014, 15, 509-524. [CrossRef]

26. De, S.; Shaknovich, R.; Riester, M.; Elemento, O.; Geng, H.; Kormaksson, M.; Jiang, Y.; Woolcock, B.; Johnson, N.; Polo, J.M.; et al. Aberration in DNA Methylation in B-Cell Lymphomas Has a Complex Origin and Increases with Disease Severity. PLoS Genet. 2013, 9, e1003137. [CrossRef]

27. Chambwe, N.; Kormaksson, M.; Geng, H.; De, S.; Michor, F.; Johnson, N.A.; Morin, R.; Scott, D.W.; Godley, L.A.; Gascoyne, R.D.; et al. Variability in DNA methylation defines novel epigenetic subgroups of DLBCL associated with different clinical outcomes. Blood 2014, 123, 1699-1708. [CrossRef]

28. Li, S.; Garrett-Bakelman, F.E.; Chung, S.S.; Sanders, M.A.; Hricik, T.; Rapaport, F.; Patel, J.; Dillon, R.; Vijay, P.; Brown, A.; et al. Distinct evolution and dynamics of epigenetic and genetic heterogeneity in acute myeloid leukemia. Nat. Med. 2016, 22, 792-799. [CrossRef]

29. Landau, D.A.; Clement, K.; Ziller, M.J.; Boyle, P.; Fan, J.; Gu, H.; Stevenson, K.; Sougnez, C.; Wang, L.; Li, S.; et al. Locally Disordered Methylation Forms the Basis of Intratumor Methylome Variation in Chronic Lymphocytic Leukemia. Cancer Cell 2014, 26, 813-825. [CrossRef]

30. Pan, H.; Renaud, L.; Chaligne, R.; Bloehdorn, J.; Tausch, E.; Mertens, D.; Fink, A.M.; Fischer, K.; Zhang, C.; Betel, D.; et al. Discovery of Candidate DNA Methylation Cancer Driver Genes. Cancer Discov. 2021, 11, 2266-2281. [CrossRef]

31. Clozel, T.; Yang, S.; Elstrom, R.L.; Tam, W.; Martin, P.; Kormaksson, M.; Banerjee, S.; VasanthaKumar, A.; Culjkovic, B.; Scott, D.W.; et al. Mechanism-Based Epigenetic Chemosensitization Therapy of Diffuse Large B-Cell Lymphoma. Cancer Discov. 2013, 3, 1002-1019. [CrossRef] [PubMed]

32. Russler-Germain, D.; Spencer, D.H.; Young, M.A.; Lamprecht, T.L.; Miller, C.; Fulton, R.; Meyer, M.R.; Erdmann-Gilmore, P.; Townsend, R.R.; Wilson, R.K.; et al. The R882H DNMT3A Mutation Associated with AML Dominantly Inhibits Wild-Type DNMT3A by Blocking Its Ability to Form Active Tetramers. Cancer Cell 2014, 25, 442-454. [CrossRef] [PubMed]

33. Qu, Y.; Lennartsson, A.; Gaidzik, V.I.; Deneberg, S.; Karimi, M.; Bengtzén, S.; Hoglund, M.; Bullinger, L.; Döhner, K.; Lehmann, S. Differential methylation in CN-AML preferentially targets non-CGI regions and is dictated byDNMT3Amutational status and associated with predominant hypomethylation of HOX genes. Epigenetics 2014, 9, 1108-1119. [CrossRef] [PubMed] 
34. Glass, J.L.; Hassane, D.; Wouters, B.J.; Kunimoto, H.; Avellino, R.; Garrett-Bakelman, F.E.; Guryanova, O.A.; Bowman, R.; Redlich, S.; Intlekofer, A.; et al. Epigenetic Identity in AML Depends on Disruption of Nonpromoter Regulatory Elements and Is Affected by Antagonistic Effects of Mutations in Epigenetic Modifiers. Cancer Discov. 2017, 7, 868-883. [CrossRef] [PubMed]

35. Ley, T.J.; Ding, L.; Walter, M.J.; McLellan, M.D.; Lamprecht, T.L.; Larson, D.E.; Kandoth, C.; Payton, J.E.; Baty, J.; Welch, J.J.; et al. DNMT3AMutations in Acute Myeloid Leukemia. N. Engl. J. Med. 2010, 363, 2424-2433. [CrossRef]

36. Shen, Y.; Zhu, Y.-M.; Fan, X.; Shi, J.-Y.; Wang, Q.-R.; Yan, X.-J.; Gu, Z.-H.; Wang, Y.-Y.; Chen, B.; Jiang, C.-L.; et al. Gene mutation patterns and their prognostic impact in a cohort of 1185 patients with acute myeloid leukemia. Blood 2011, 118, 5593-5603. [CrossRef] [PubMed]

37. Grossmann, V.; Haferlach, C.; Weissmann, S.; Roller, A.; Schindela, S.; Poetzinger, F.; Stadler, K.; Bellos, F.; Kern, W.; Haferlach, T.; et al. The molecular profile of adult T-cell acute lymphoblastic leukemia: Mutations inRUNX1andDNMT3Aare associated with poor prognosis in T-ALL. Genes Chromosom. Cancer 2013, 52, 410-422. [CrossRef]

38. Roller, A.; Grossmann, V.; Bacher, U.; Poetzinger, F.; Weissmann, S.; Nadarajah, N.; Boeck, L.; Kern, W.; Haferlach, T.; Schnittger, S.; et al. Landmark analysis of DNMT3A mutations in hematological malignancies. Leukemia 2013, 27, 1573-1578. [CrossRef]

39. Shlush, L.I.; Zandi, S.; Mitchell, A.; Chen, W.C.; Brandwein, J.M.; Gupta, V.; Kennedy, J.A.; Schimmer, A.; Schuh, A.C.; Yee, K.W.; et al. Identification of pre-leukaemic haematopoietic stem cells in acute leukaemia. Nature 2014, 506, 328-333. [CrossRef]

40. Poole, C.J.; Zheng, W.; Lodh, A.; Yevtodiyenko, A.; Liefwalker, D.; Li, H.; Felsher, D.W.; Van Riggelen, J. DNMT3B overexpression contributes to aberrant DNA methylation and MYC-driven tumor maintenance in T-ALL and Burkitt's lymphoma. Oncotarget 2017, 8, 76898-76920. [CrossRef]

41. Robaina, M.C.; Mazzoccoli, L.; Arruda, V.O.; Reis, F.R.D.S.; Apa, A.G.; de Rezende, L.M.M.; Klumb, C.E. Deregulation of DNMT1, DNMT3B and miR-29s in Burkitt lymphoma suggests novel contribution for disease pathogenesis. Exp. Mol. Pathol. 2015, 98, 200-207. [CrossRef]

42. Amara, K.; Ziadi, S.; Hachana, M.; Soltani, N.; Korbi, S.; Trimeche, M. DNA methyltransferase DNMT3b protein overexpression as a prognostic factor in patients with diffuse large B-cell lymphomas. Cancer Sci. 2010, 101, 1722-1730. [CrossRef]

43. Pawlyn, C.; Kaiser, M.F.; Heuck, C.; Melchor, L.; Wardell, C.; Murison, A.; Chavan, S.S.; Johnson, D.C.; Begum, D.B.; Dahir, N.M.; et al. The Spectrum and Clinical Impact of Epigenetic Modifier Mutations in Myeloma. Clin. Cancer Res. 2016, 22, 5783-5794. [CrossRef] [PubMed]

44. Tessoulin, B.; Moreau-Aubry, A.; Descamps, G.; Bougie, P.G.; Maïga, S.; Gaignard, A.; Chiron, D.; Ménoret, E.; le Gouill, S.; Moreau, P.; et al. Whole-exon sequencing of human myeloma cell lines shows mutations related to myeloma patients at relapse with major hits in the DNA regulation and repair pathways. J. Hematol. Oncol. 2018, 11, 1-13. [CrossRef] [PubMed]

45. Bollati, V.; Fabris, S.; Pegoraro, V.; Ronchetti, D.; Mosca, L.; Deliliers, G.L.; Motta, V.; Bertazzi, P.A.; Baccarelli, A.; Neri, A. Differential repetitive DNA methylation in multiple myeloma molecular subgroups. Carcinogenesis 2009, 30, 1330-1335. [CrossRef] [PubMed]

46. Sive, J.I.; Feber, A.; Smith, D.; Quinn, J.; Beck, S.; Yong, K. Global hypomethylation in myeloma is associated with poor prognosis. Br. J. Haematol. 2015, 172, 473-475. [CrossRef] [PubMed]

47. Houde, C.; Li, Y.; Song, L.; Barton, K.; Zhang, Q.; Godwin, J.; Nand, S.; Toor, A.; Alkan, S.; Smadja, N.V.; et al. Overexpression of the NOTCH ligand JAG2 in malignant plasma cells from multiple myeloma patients and cell lines. Blood 2004, 104, 3697-3704. [CrossRef] [PubMed]

48. Turner, J.G.; Gump, J.L.; Zhang, C.; Cook, J.M.; Marchion, D.; Hazlehurst, L.; Munster, P.; Schell, M.J.; Dalton, W.S.; Sullivan, D.M. ABCG2 expression, function, and promoter methylation in human multiple myeloma. Blood 2006, 108, 3881-3889. [CrossRef] [PubMed]

49. Alzrigat, M.; Atienza-Párraga, A.; Jernberg-Wiklund, H. Epigenetics in multiple myeloma: From mechanisms to therapy. Semin Cancer Biol. 2018, 51, 101-115. [CrossRef] [PubMed]

50. Kaiser, M.F.; Johnson, D.C.; Wu, P.; Walker, B.; Brioli, A.; Mirabella, F.; Wardell, C.; Melchor, L.; Davies, F.; Morgan, G. Global methylation analysis identifies prognostically important epigenetically inactivated tumor suppressor genes in multiple myeloma. Blood 2013, 122, 219-226. [CrossRef]

51. Walker, B.A.; Wardell, C.; Chiecchio, L.; Smith, E.M.; Boyd, K.; Neri, A.; Davies, F.E.; Ross, F.M.; Morgan, G. Aberrant global methylation patterns affect the molecular pathogenesis and prognosis of multiple myeloma. Blood 2011, 117, 553-562. [CrossRef]

52. Heuck, C.J.; Mehta, J.; Bhagat, T.; Gundabolu, K.; Yu, Y.; Khan, S.; Chrysofakis, G.; Schinke, C.; Tariman, J.D.; Vickrey, E.; et al. Myeloma Is Characterized by Stage-Specific Alterations in DNA Methylation That Occur Early during Myelomagenesis. J. Immunol. 2013, 190, 2966-2975. [CrossRef]

53. Agirre, X.; Castellano, G.; Pascual, M.; Heath, S.; Kulis, M.; Segura, V.; Bergmann, A.; Esteve-Codina, A.; Merkel, A.; Raineri, E.; et al. Whole-epigenome analysis in multiple myeloma reveals DNA hypermethylation of B cell-specific enhancers. Genome Res. 2015, 25, 478-487. [CrossRef]

54. Choudhury, S.R.; Ashby, C.; Tytarenko, R.; Bauer, M.; Wang, Y.; Deshpande, S.; Den, J.; Schinke, C.; Zangari, M.; Thanendrarajan, S.; et al. The functional epigenetic landscape of aberrant gene expression in molecular subgroups of newly diagnosed multiple myeloma. J. Hematol. Oncol. 2020, 13, 1-15. [CrossRef]

55. Alberge, J.-B.; Magrangeas, F.; Wagner, M.; Denié, S.; Guérin-Charbonnel, C.; Campion, L.; Attal, M.; Avet-Loiseau, H.; Carell, T.; Moreau, P.; et al. DNA hydroxymethylation is associated with disease severity and persists at enhancers of oncogenic regions in multiple myeloma. Clin. Epigenetics 2020, 12, 1-12. [CrossRef] 
56. Chatonnet, F.; Pignarre, A.; Sérandour, A.A.; Caron, G.; Avner, S.; Robert, N.; Kassambara, A.; Laurent, A.; Bizot, M.; Agirre, X.; et al. The hydroxymethylome of multiple myeloma identifies FAM72D as a 1q21 marker linked to proliferation. Haematologica 2019, 105, 774-783. [CrossRef] [PubMed]

57. Chou, W.-C.; Chou, S.-C.; Liu, C.-Y.; Chen, C.-Y.; Hou, H.-A.; Kuo, Y.-Y.; Lee, M.-C.; Ko, B.-S.; Tang, J.-L.; Yao, M.; et al. TET2 mutation is an unfavorable prognostic factor in acute myeloid leukemia patients with intermediate-risk cytogenetics. Blood 2011, 118, 3803-3810. [CrossRef]

58. Weissmann, S.; Alpermann, T.; Grossmann, V.; Kowarsch, A.; Nadarajah, N.; Eder, C.; Dicker, F.; Fasan, A.; Haferlach, C.; Kern, W.; et al. Landscape of TET2 mutations in acute myeloid leukemia. Leukemia 2011, 26, 934-942. [CrossRef] [PubMed]

59. Abdel-Wahab, O.; Mullally, A.; Hedvat, C.; Garcia-Manero, G.; Patel, J.; Wadleigh, M.; Malinge, S.; Yao, J.J.; Kilpivaara, O.; Bhat, R.; et al. Genetic characterization of TET1, TET2, and TET3 alterations in myeloid malignancies. Blood 2009, 114, 144-147. [CrossRef] [PubMed]

60. Delhommeau, F.; Dupont, S.; Della Valle, V.; James, C.; Trannoy, S.; Massé, A.; Kosmider, O.; Le Couedic, J.-P.; Robert, F.; Alberdi, A.; et al. Mutation inTET2in Myeloid Cancers. N. Engl. J. Med. 2009, 360, 2289-2301. [CrossRef] [PubMed]

61. Langemeijer, S.M.C.; Kuiper, R.P.; Berends, M.; Knops, R.; Aslanyan, M.G.; Massop, M.; Stevens-Linders, E.; Van Hoogen, P.; Van Kessel, A.G.; Raymakers, R.A.P.; et al. Acquired mutations in TET2 are common in myelodysplastic syndromes. Nat. Genet. 2009, 41, 838-842. [CrossRef] [PubMed]

62. Jankowska, A.M.; Szpurka, H.; Tiu, R.V.; Makishima, H.; Afable, M.; Huh, J.; O’Keefe, C.L.; Ganetzky, R.; McDevitt, M.A.; Maciejewski, J.P. Loss of heterozygosity 4q24 and TET2 mutations associated with myelodysplastic/myeloproliferative neoplasms. Blood 2009, 113, 6403-6410. [CrossRef] [PubMed]

63. Quivoron, C.; Couronné, L.; Della Valle, V.; Lopez, C.; Plo, I.; Wagner-Ballon, O.; Cruzeiro, M.D.; Delhommeau, F.; Arnulf, B.; Stern, M.-H.; et al. TET2 Inactivation Results in Pleiotropic Hematopoietic Abnormalities in Mouse and Is a Recurrent Event during Human Lymphomagenesis. Cancer Cell 2011, 20, 25-38. [CrossRef] [PubMed]

64. Dominguez, P.M.; Ghamlouch, H.; Rosikiewicz, W.; Kumar, P.; Béguelin, W.; Fontan, L.; Rivas, M.A.; Pawlikowska, P.; Armand, M.; Mouly, E.; et al. TET2 deficiency causes germinal center hyperplasia, impairs plasma cell differentiation and promotes B-cell lymphomagenesis. Cancer Discov. 2018, 8, CD-18-0657-18. [CrossRef] [PubMed]

65. Cimmino, L.; Dolgalev, I.; Wang, Y.; Yoshimi, A.; Martin, G.; Wang, J.; Ng, V.; Xia, B.; Witkowski, M.; Mitchell-Flack, M.; et al. Restoration of TET2 Function Blocks Aberrant Self-Renewal and Leukemia Progression. Cell 2017, 170, 1079-1095.e20. [CrossRef]

66. Paschka, P.; Schlenk, R.F.; Gaidzik, V.I.; Habdank, M.; Krönke, J.; Bullinger, L.; Späth, D.; Kayser, S.; Zucknick, M.; Götze, K.; et al. IDH1 and IDH2 Mutations Are Frequent Genetic Alterations in Acute Myeloid Leukemia and Confer Adverse Prognosis in Cytogenetically Normal Acute Myeloid Leukemia With NPM1 Mutation Without FLT3 Internal Tandem Duplication. J. Clin. Oncol. 2010, 28, 3636-3643. [CrossRef]

67. Abbas, S.; Lugthart, S.; Kavelaars, F.; Schelen, A.; Koenders, J.; Zeilemaker, A.; Van Putten, W.J.L.; Rijneveld, A.; Löwenberg, B.; Valk, P. Acquired mutations in the genes encoding IDH1 and IDH2 both are recurrent aberrations in acute myeloid leukemia: Prevalence and prognostic value. Blood 2010, 116, 2122-2126. [CrossRef]

68. Mardis, E.R.; Ding, L.; Dooling, D.J.; Larson, D.E.; McLellan, M.D.; Chen, K.; Koboldt, D.C.; Fulton, R.S.; Delehaunty, K.D.; McGrath, S.D.; et al. Recurring Mutations Found by Sequencing an Acute Myeloid Leukemia Genome. N. Engl. J. Med. 2009, 361, 1058-1066. [CrossRef]

69. Figueroa, M.E.; Abdel-Wahab, O.; Lu, C.; Ward, P.; Patel, J.; Shih, A.; Li, Y.; Bhagwat, N.; VasanthaKumar, A.; Fernandez, H.F.; et al. Leukemic IDH1 and IDH2 Mutations Result in a Hypermethylation Phenotype, Disrupt TET2 Function, and Impair Hematopoietic Differentiation. Cancer Cell 2010, 18, 553-567. [CrossRef]

70. Ward, P.; Cross, J.; Lu, C.; Weigert, O.; Abel-Wahab, O.; Levine, R.L.; Weinstock, D.M.; Sharp, K.A.; Thompson, C.B. Identification of additional IDH mutations associated with oncometabolite R(-)-2-hydroxyglutarate production. Oncogene 2011, 31, 2491-2498. [CrossRef]

71. Gross, S.; Cairns, R.A.; Minden, M.D.; Driggers, E.M.; Bittinger, M.A.; Jang, H.G.; Sasaki, M.; Jin, S.; Schenkein, D.P.; Su, S.M.; et al. Cancer-associated metabolite 2-hydroxyglutarate accumulates in acute myelogenous leukemia with isocitrate dehydrogenase 1 and 2 mutations. J. Exp. Med. 2010, 207, 339-344. [CrossRef]

72. Dang, L.; White, D.W.; Gross, S.; Bennett, B.D.; Bittinger, M.A.; Driggers, E.M.; Fantin, V.R.; Jang, H.G.; Jin, S.; Keenan, M.C.; et al. Cancer-associated IDH1 mutations produce 2-hydroxyglutarate. Nature 2010, 465, 966. [CrossRef]

73. Lu, C.; Ward, P.; Kapoor, G.S.; Rohle, D.; Turcan, S.; Abdel-Wahab, O.; Edwards, C.R.; Khanin, R.; Figueroa, M.E.; Melnick, A.; et al. IDH mutation impairs histone demethylation and results in a block to cell differentiation. Nature 2012, 483, 474-478. [CrossRef] [PubMed]

74. Xu, W.; Yang, H.; Liu, Y.; Yang, Y.; Wang, P.; Kim, S.-H.; Ito, S.; Yang, C.; Wang, P.; Xiao, M.-T.; et al. Oncometabolite 2Hydroxyglutarate Is a Competitive Inhibitor of $\alpha$-Ketoglutarate-Dependent Dioxygenases. Cancer Cell 2011, 19, 17-30. [CrossRef] [PubMed]

75. Chowdhury, R.; Yeoh, K.K.; Tian, Y.; Hillringhaus, L.; Bagg, E.; Rose, N.; Leung, I.; Li, X.S.; Woon, E.; Yang, M.; et al. The oncometabolite 2-hydroxyglutarate inhibits histone lysine demethylases. EMBO Rep. 2011, 12, 463-469. [CrossRef] [PubMed]

76. Rampal, R.; Akalin, A.; Madzo, J.; Vasanthakumar, A.; Pronier, E.; Patel, J.; Li, Y.; Ahn, J.; Abdel-Wahab, O.; Shih, A.; et al. DNA Hydroxymethylation Profiling Reveals that WT1 Mutations Result in Loss of TET2 Function in Acute Myeloid Leukemia. Cell Rep. 2014, 9, 1841-1855. [CrossRef] [PubMed] 
77. Chaturvedi, A.; Gupta, C.; Gabdoulline, R.; Borchert, N.M.; Goparaju, R.; Kaulfuss, S.; Görlich, K.; Schottmann, R.; Othman, B.; Welzenbach, J.; et al. Synergistic activity of IDH1 inhibitor BAY1436032 with azacitidine in IDH1 mutant acute myeloid leukemia. Haematologica 2020, 106, 565-573. [CrossRef]

78. Dupéré-Richer, D.; Licht, J.D. Epigenetic regulatory mutations and epigenetic therapy for multiple myeloma. Curr. Opin. Hematol. 2017, 24, 336-344. [CrossRef]

79. der Poel, S.Z.-V.; McCabe, N.R.; Gill, H.J.; Espinosa, R.; Patel, Y.; Harden, A.; Rubinelli, P.; Smith, S.D.; LeBeau, M.M.; Rowley, J.D. Identification of a gene, MLL, that spans the breakpoint in 11q23 translocations associated with human leukemias. Proc. Natl. Acad. Sci. USA 1991, 88, 10735-10739. [CrossRef]

80. Tkachuk, D.C.; Kohler, S.; Cleary, M.L. Involvement of a homolog of Drosophila trithorax by 11q23 chromosomal translocations in acute leukemias. Cell 1992, 71, 691-700. [CrossRef]

81. Gu, Y.; Nakamura, T.; Alder, H.; Prasad, R.; Canaani, O.; Cimino, G.; Croce, C. The t(4;11) chromosome translocation of human acute leukemias fuses the ALL-1 gene, related to Drosophila trithorax, to the AF-4 gene. Cell 1992, 71, 701-708. [CrossRef]

82. McCabe, N.R.; Burnett, R.C.; Gill, H.J.; Thirman, M.J.; Mbangkollo, D.; Kipiniak, M.; van Melle, E.; der Poel, S.Z.-V.; Rowley, J.D.; Diaz, M.O. Cloning of cDNAs of the MLL gene that detect DNA rearrangements and altered RNA transcripts in human leukemic cells with 11q23 translocations. Proc. Natl. Acad. Sci. USA 1992, 89, 11794-11798. [CrossRef] [PubMed]

83. Meyer, C.; Hofmann, J.; Burmeister, T.; Gröger, D.; Park, T.S.; Emerenciano, M.; Pombo-De-Oliveira, M.S.; Renneville, A.; Villarese, P.; Macintyre, E.; et al. The MLL recombinome of acute leukemias in 2013. Leukemia 2013, 27, 2165-2176. [CrossRef] [PubMed]

84. Meyer, C.; Burmeister, T.; Gröger, D.; Tsaur, G.; Fechina, L.; Renneville, A.; Sutton, R.; Venn, N.C.; Emerenciano, M.; Pombo-DeOliveira, M.S.; et al. The MLL recombinome of acute leukemias in 2017. Leukemia 2017, 32, 273-284. [CrossRef]

85. Erfurth, F.; Hemenway, C.S.; De Erkenez, A.C.; Domer, P.H. MLL fusion partners AF4 and AF9 interact at subnuclear foci. Leukemia 2003, 18, 92-102. [CrossRef]

86. Zeisig, D.T.; Bittner, C.B.; Zeisig, B.B.; García-Cuéllar, M.-P.; Hess, J.L.; Slany, R.K. The eleven-nineteen-leukemia protein ENL connects nuclear MLL fusion partners with chromatin. Oncogene 2005, 24, 5525-5532. [CrossRef]

87. Mueller, D.; Bach, C.; Zeisig, D.; Garcia-Cuellar, M.-P.; Monroe, S.; Sreekumar, A.; Zhou, R.; Nesvizhskii, A.; Chinnaiyan, A.; Hess, J.L.; et al. A role for the MLL fusion partner ENL in transcriptional elongation and chromatin modification. Blood 2007, 110, 4445-4454. [CrossRef]

88. Shilatifard, A.; Lane, W.S.; Jackson, K.W.; Conaway, R.C.; Conaway, J. An RNA Polymerase II Elongation Factor Encoded by the Human ELL Gene. Science 1996, 271, 1873-1876. [CrossRef]

89. Hetzner, K.; Garcia-Cuellar, M.-P.; Büttner, C.; Slany, R.K. The interaction of ENL with PAF1 mitigates polycomb silencing and facilitates murine leukemogenesis. Blood 2018, 131, 662-673. [CrossRef] [PubMed]

90. García-Cuéllar, M.P.; Zilles, O.; Schreiner, S.A.; Birke, M.; Winkler, T.H.; Slany, R.K. The ENL moiety of the childhood leukemiaassociated MLL-ENL oncoprotein recruits human Polycomb 3. Oncogene 2001, 20, 411-419. [CrossRef]

91. Lavau, C.; Du, C.; Thirman, M.; Zeleznik-Le, N. Chromatin-related properties of CBP fused to MLL generate a myelodysplasticlike syndrome that evolves into myeloid leukemia. EMBO J. 2000, 19, 4655-4664. [CrossRef]

92. Au, Y.Z.; Gu, M.; De Braekeleer, E.; Gozdecka, M.; Aspris, D.; Tarumoto, Y.; Cooper, J.; Yu, J.; Ong, S.H.; Chen, X.; et al. KAT7 is a genetic vulnerability of acute myeloid leukemias driven by MLL rearrangements. Leukemia 2020, 35, 1012-1022. [CrossRef] [PubMed]

93. Bernt, K.; Armstrong, S.A. Targeting Epigenetic Programs in MLL-Rearranged Leukemias. Hematology 2011, $2011,354-360$. [CrossRef]

94. Xu, X.; Schneider, B. Therapeutic targeting potential of chromatin-associated proteins in MLL-rearranged acute leukemia. Cell. Oncol. 2018, 42, 117-130. [CrossRef] [PubMed]

95. Cao, M.; Li, T.; Chen, Y.; Zhai, X. Nucleoside and Non-Nucleoside DOT1L Inhibitors: Dawn of MLLrearranged Leukemia. Mini-Rev. Med. Chem. 2021, 21, 1337-1350. [CrossRef]

96. Morgan, M.A.; Shilatifard, A. Chromatin signatures of cancer. Genes Dev. 2015, 29, 238-249. [CrossRef] [PubMed]

97. Mrózek, K. Cytogenetic, Molecular Genetic, and Clinical Characteristics of Acute Myeloid Leukemia With a Complex Karyotype. Semin. Oncol. 2008, 35, 365-377. [CrossRef]

98. Pasqualucci, L.; Dominguez-Sola, D.; Chiarenza, A.; Fabbri, G.; Grunn, A.; Trifonov, V.; Kasper, L.H.; Lerach, S.; Tang, H.; Ma, J.; et al. Inactivating mutations of acetyltransferase genes in B-cell lymphoma. Nature 2011, 471, 189-195. [CrossRef]

99. Zhang, J.; Grubor, V.; Love, C.L.; Banerjee, A.; Richards, K.L.; Mieczkowski, P.; Dunphy, C.; Choi, W.; Au, W.Y.; Srivastava, G.; et al. Genetic heterogeneity of diffuse large B-cell lymphoma. Proc. Natl. Acad. Sci. USA 2013, 110, 1398-1403. [CrossRef]

100. Morin, R.D.; Mendez-Lago, M.; Mungall, A.; Goya, R.; Mungall, K.L.; Corbett, R.D.; Johnson, N.A.; Severson, T.M.; Chiu, R.; Field, M.; et al. Frequent mutation of histone-modifying genes in non-Hodgkin lymphoma. Nature 2011, 476, 298-303. [CrossRef]

101. Lohr, J.G.; Stojanov, P.; Lawrence, M.S.; Auclair, D.; Chapuy, B.; Sougnez, C.; Cruz-Gordillo, P.; Knoechel, B.; Asmann, Y.W.; Slager, S.L.; et al. Discovery and prioritization of somatic mutations in diffuse large B-cell lymphoma (DLBCL) by whole-exome sequencing. Proc. Natl. Acad. Sci. USA 2012, 109, 3879-3884. [CrossRef] [PubMed]

102. Green, M.R.; Kihira, S.; Liu, C.L.; Nair, R.V.; Salari, R.; Gentles, A.J.; Irish, J.; Stehr, H.; Vicente-Dueñas, C.; Romero-Camarero, I.; et al. Mutations in early follicular lymphoma progenitors are associated with suppressed antigen presentation. Proc. Natl. Acad. Sci. USA 2015, 112, E1116-E1125. [CrossRef] [PubMed] 
103. Mar, B.G.; Bullinger, L.; Basu, E.; Schlis, K.; Silverman, L.B.; Döhner, K.; Armstrong, S.A. Sequencing histone-modifying enzymes identifies UTX mutations in acute lymphoblastic leukemia. Leukemia 2012, 26, 1881-1883. [CrossRef] [PubMed]

104. Lindqvist, C.M.; Nordlund, J.; Ekman, D.; Johansson, A.; Moghadam, B.T.; Raine, A.; Övernäs, E.; Dahlberg, J.; Wahlberg, P.; Henriksson, N.; et al. The Mutational Landscape in Pediatric Acute Lymphoblastic Leukemia Deciphered by Whole Genome Sequencing. Hum. Mutat. 2014, 36, 118-128. [CrossRef]

105. Neumann, M.; Vosberg, S.; Schlee, C.; Heesch, S.; Schwartz, S.; Gökbuget, N.; Hoelzer, D.; Graf, A.; Krebs, S.; Bartram, I.; et al. Mutational spectrum of adult T-ALL. Oncotarget 2014, 6, 2754-2766. [CrossRef]

106. Kandoth, C.; McLellan, M.D.; Vandin, F.; Ye, K.; Niu, B.; Lu, C.; Xie, M.; Zhang, Q.; McMichael, J.F.; Wyczalkowski, M.; et al. Mutational landscape and significance across 12 major cancer types. Nat. Cell Biol. 2013, 502, 333-339. [CrossRef]

107. Herz, H.-M.; Hu, D.; Shilatifard, A. Enhancer Malfunction in Cancer. Mol. Cell 2014, 53, 859-866. [CrossRef]

108. Ortega-Molina, A.; Boss, I.W.; Canela, A.; Pan, H.; Jiang, Y.; Zhao, C.; Jiang, M.; Hu, D.; Agirre, X.; Niesvizky, I.; et al. The histone lysine methyltransferase KMT2D sustains a gene expression program that represses B cell lymphoma development. Nat. Med. 2015, 21, 1199-1208. [CrossRef]

109. Zhang, J.; Dominguez-Sola, D.; Hussein, S.; Lee, J.-E.; Holmes, A.B.; Bansal, M.; Vlasevska, S.; Mo, T.; Tang, H.; Basso, K.; et al. Disruption of KMT2D perturbs germinal center B cell development and promotes lymphomagenesis. Nat. Med. 2015, 21, 1190-1198. [CrossRef]

110. Vikova, V.; Jourdan, M.; Robert, N.; Requirand, G.; Boireau, S.; Bruyer, A.; Vincent, L.; Cartron, G.; Klein, B.; Elemento, O.; et al. Comprehensive characterization of the mutational landscape in multiple myeloma cell lines reveals potential drivers and pathways associated with tumor progression and drug resistance. Theranostics 2019, 9, 540-553. [CrossRef] [PubMed]

111. Kroeze, L.; Nikoloski, G.; Da Silva-Coelho, P.; Van Hoogen, P.; Stevens-Linders, E.; Kuiper, R.P.; Schnittger, S.; Haferlach, T.; Pahl, H.L.; Van Der Reijden, B.A.; et al. Genetic defects in PRC2 components other than EZH2 are not common in myeloid malignancies. Blood 2012, 119, 1318-1319. [CrossRef]

112. Woods, B.A.; Levine, R.L. The role of mutations in epigenetic regulators in myeloid malignancies. Immunol. Rev. 2014, 263, 22-35. [CrossRef]

113. Ernst, T.; Chase, A.J.; Score, J.; Hidalgo-Curtis, C.E.; Bryant, C.; Jones, A.V.; Waghorn, K.; Zoi, K.; Ross, F.M.; Reiter, A.; et al. Inactivating mutations of the histone methyltransferase gene EZH2 in myeloid disorders. Nat. Genet. 2010, 42, 722-726. [CrossRef]

114. Ernst, T.; Pflug, A.; Rinke, J.; Ernst, J.; Bierbach, U.; Beck, J.F.; Hochhaus, A.; Gruhn, B. A somatic EZH2 mutation in childhood acute myeloid leukemia. Leukemia 2012, 26, 1701-1703. [CrossRef]

115. Nikoloski, G.; Langemeijer, S.M.C.; Kuiper, R.P.; Knops, R.; Massop, M.; Tönnissen, E.R.L.T.M.; Van Der Heijden, A.; Scheele, T.N.; Vandenberghe, P.; De Witte, T.; et al. Somatic mutations of the histone methyltransferase gene EZH2 in myelodysplastic syndromes. Nat. Genet. 2010, 42, 665-667. [CrossRef]

116. Ntziachristos, P.; Tsirigos, A.; Van Vlierberghe, P.; Nedjic, J.; Trimarchi, T.; Flaherty, M.S.; Ferres-Marco, D.; Da Ros, V.G.; Tang, Z.; Siegle, J.; et al. Genetic inactivation of the polycomb repressive complex 2 in T cell acute lymphoblastic leukemia. Nat. Med. 2012, 18, 298-302. [CrossRef]

117. Score, J.; Hidalgo-Curtis, C.; Jones, A.V.; Winkelmann, N.; Skinner, A.; Ward, D.; Zoi, K.; Ernst, T.; Stegelmann, F.; Döhner, K.; et al. Inactivation of polycomb repressive complex 2 components in myeloproliferative and myelodysplastic/myeloproliferative neoplasms. Blood 2012, 119, 1208-1213. [CrossRef]

118. Simon, C.; Chagraoui, J.; Krosl, J.; Gendron, P.; Wilhelm, B.; Lemieux, S.; Boucher, G.; Chagnon, P.; Drouin, S.; Lambert, R.; et al. A key role for EZH2 and associated genes in mouse and human adult T-cell acute leukemia. Genes Dev. 2012, 26, 651-656. [CrossRef] [PubMed]

119. Zhang, J.; Ding, L.; Holmfeldt, L.; Wu, G.; Heatley, S.; Payne-Turner, D.; Easton, J.; Chen, X.; Wang, J.; Rusch, M.; et al. The genetic basis of early T-cell precursor acute lymphoblastic leukaemia. Nature 2012, 481, 157-163. [CrossRef] [PubMed]

120. Grossmann, V.; Kohlmann, A.; Zenger, M.; Schindela, S.; Eder, C.; Weissmann, S.; Schnittger, S.; Kern, W.; Muller, M.C.; Hochhaus, A.; et al. A deep-sequencing study of chronic myeloid leukemia patients in blast crisis (BC-CML) detects mutations in $76.9 \%$ of cases. Leukemia 2011, 25, 557-560. [CrossRef] [PubMed]

121. Guglielmelli, P.; Biamonte, F.; Score, J.; Hidalgo-Curtis, C.; Cervantes, F.; Maffioli, M.; Fanelli, T.; Ernst, T.; Winkelman, N.; Jones, A.V.; et al. EZH2 mutational status predicts poor survival in myelofibrosis. Blood 2011, 118, 5227-5234. [CrossRef]

122. Morin, R.D.; Johnson, N.A.; Severson, T.M.; Mungall, A.; An, J.; Goya, R.; Paul, J.E.; Boyle, M.; Woolcock, B.W.; Kuchenbauer, F.; et al. Somatic mutations altering EZH2 (Tyr641) in follicular and diffuse large B-cell lymphomas of germinal-center origin. Nat. Genet. 2010, 42, 181-185. [CrossRef] [PubMed]

123. Bödör, C.; Grossmann, V.; Popov, N.; Okosun, J.; O’Riain, C.; Tan, K.; Marzec, J.; Araf, S.; Wang, J.; Lee, A.M.; et al. EZH2 mutations are frequent and represent an early event in follicular lymphoma. Blood 2013, 122, 3165-3168. [CrossRef] [PubMed]

124. Okosun, J.; Bödör, C.; Wang, J.; Araf, S.; Yang, C.-Y.; Pan, C.; Boller, S.; Cittaro, D.; Bozek, M.; Iqbal, S.; et al. Integrated genomic analysis identifies recurrent mutations and evolution patterns driving the initiation and progression of follicular lymphoma. Nat. Genet. 2013, 46, 176-181. [CrossRef] [PubMed]

125. Reddy, A.; Zhang, J.; Davis, N.S.; Moffitt, A.; Love, C.L.; Waldrop, A.; Leppä, S.; Pasanen, A.; Meriranta, L.; Karjalainen-Lindsberg, M.-L.; et al. Genetic and Functional Drivers of Diffuse Large B Cell Lymphoma. Cell 2017, 171, 481-494.e15. [CrossRef] 
126. Sneeringer, C.J.; Scott, M.P.; Kuntz, K.W.; Knutson, S.K.; Pollock, R.M.; Richon, V.M.; Copeland, R.A. Coordinated activities of wild-type plus mutant EZH2 drive tumor-associated hypertrimethylation of lysine 27 on histone H3 (H3K27) in human B-cell lymphomas. Proc. Natl. Acad. Sci. USA 2010, 107, 20980-20985. [CrossRef]

127. Yap, D.; Chu, J.; Berg, T.; Schapira, M.; Cheng, S.-W.G.; Moradian, A.; Morin, R.D.; Mungall, A.; Meissner, B.; Boyle, M.; et al. Somatic mutations at EZH2 Y641 act dominantly through a mechanism of selectively altered PRC2 catalytic activity, to increase H3K27 trimethylation. Blood 2011, 117, 2451-2459. [CrossRef]

128. McCabe, M.T.; Graves, A.P.; Ganji, G.; Diaz, E.; Halsey, W.S.; Jiang, Y.; Smitheman, K.N.; Ott, H.M.; Pappalardi, M.B.; Allen, K.E.; et al. Mutation of A677 in histone methyltransferase EZH2 in human B-cell lymphoma promotes hypertrimethylation of histone H3 on lysine 27 (H3K27). Proc. Natl. Acad. Sci. USA 2012, 109, 2989-2994. [CrossRef]

129. Béguelin, W.; Popovic, R.; Teater, M.; Jiang, Y.; Bunting, K.L.; Rosen, M.; Shen, H.; Yang, S.N.; Wang, L.; Ezponda, T.; et al. EZH2 Is Required for Germinal Center Formation and Somatic EZH2 Mutations Promote Lymphoid Transformation. Cancer Cell 2013, 23, 677-692. [CrossRef]

130. Béguelin, W.; Teater, M.; Gearhart, M.; Fernández, M.T.C.; Goldstein, R.L.; Cárdenas, M.G.; Hatzi, K.; Rosen, M.; Shen, H.; Corcoran, C.M.; et al. EZH2 and BCL6 Cooperate to Assemble CBX8-BCOR Complex to Repress Bivalent Promoters, Mediate Germinal Center Formation and Lymphomagenesis. Cancer Cell 2016, 30, 197-213. [CrossRef]

131. Herviou, L.; Jourdan, M.; Martinez, A.-M.; Cavalli, G.; Moreaux, J. EZH2 is overexpressed in transitional preplasmablasts and is involved in human plasma cell differentiation. Leukemia 2019, 33, 2047-2060. [CrossRef] [PubMed]

132. Croonquist, P.A.; Van Ness, B. The polycomb group protein enhancer of zeste homolog 2 (EZH2) is an oncogene that influences myeloma cell growth and the mutant ras phenotype. Oncogene 2005, 24, 6269-6280. [CrossRef]

133. Ishiguro, K.; Kitajima, H.; Niinuma, T.; Maruyama, R.; Nishiyama, N.; Ohtani, H.; Sudo, G.; Toyota, M.; Sasaki, H.; Yamamoto, E.; et al. Dual EZH2 and G9a inhibition suppresses multiple myeloma cell proliferation by regulating the interferon signal and IRF4-MYC axis. Cell Death Discov. 2021, 7, 1-13. [CrossRef] [PubMed]

134. Agarwal, P.; Alzrigat, M.; Atienza-Párraga, A.; Enroth, S.; Singh, U.; Ungerstedt, J.; Österborg, A.; Brown, P.; Ma, A.; Jin, J.; et al. Genome-wide profiling of histone $\mathrm{H} 3$ lysine 27 and lysine 4 trimethylation in multiple myeloma reveals the importance of Polycomb gene targeting and highlights EZH2 as a potential therapeutic target. Oncotarget 2016, 7, 6809-6823. [CrossRef] [PubMed]

135. Kalushkova, A.; Fryknäs, M.; Lemaire, M.; Fristedt, C.; Agarwal, P.; Eriksson, M.; Deleu, S.; Atadja, P.; Österborg, A.; Nilsson, K.; et al. Polycomb Target Genes Are Silenced in Multiple Myeloma. PLoS ONE 2010, 5, e11483. [CrossRef] [PubMed]

136. Herviou, L.; Kassambara, A.; Boireau, S.; Robert, N.; Requirand, G.; Müller-Tidow, C.; Vincent, L.; Seckinger, A.; Goldschmidt, H.; Cartron, G.; et al. PRC2 targeting is a therapeutic strategy for EZ score defined high-risk multiple myeloma patients and overcome resistance to IMiDs. Clin. Epigenetics 2018, 10, 121. [CrossRef]

137. Harding, T.; Swanson, J.; Van Ness, B. EZH2 inhibitors sensitize myeloma cell lines to panobinostat resulting in unique combinatorial transcriptomic changes. Oncotarget 2018, 9, 21930-21942. [CrossRef]

138. Hernando, H.; Gelato, K.A.; Lesche, R.; Beckmann, G.; Koehr, S.; Otto, S.; Steigemann, P.; Stresemann, C. EZH2 Inhibition Blocks Multiple Myeloma Cell Growth through Upregulation of Epithelial Tumor Suppressor Genes. Mol. Cancer Ther. 2015, 15, 287-298. [CrossRef]

139. Pawlyn, C.; Bright, M.; Buros, A.F.; Stein, C.K.; Walters, Z.; Aronson, L.; Mirabella, F.; Jones, J.R.; Kaiser, M.F.; Walker, B.; et al Overexpression of EZH2 in multiple myeloma is associated with poor prognosis and dysregulation of cell cycle control. Blood Cancer J. 2017, 7, e549. [CrossRef]

140. Zeng, D.; Liu, M.; Pan, J. Blocking EZH2 methylation transferase activity by GSK126 decreases stem cell-like myeloma cells. Oncotarget 2016, 8, 3396-3411. [CrossRef]

141. Ren, Z.; Ahn, J.H.; Liu, H.; Tsai, Y.-H.; Bhanu, N.V.; Koss, B.; Allison, D.F.; Ma, A.; Storey, A.J.; Wang, P.; et al. PHF19 promotes multiple myeloma tumorigenicity through PRC2 activation and broad H3K27me3 domain formation. Blood 2019, 134, 1176-1189. [CrossRef]

142. Rizk, M.; Rizq, O.; Oshima, M.; Nakajima-Takagi, Y.; Koide, S.; Saraya, A.; Isshiki, Y.; Chiba, T.; Yamazaki, S.; Ma, A.; et al. Akt inhibition synergizes with polycomb repressive complex 2 inhibition in the treatment of multiple myeloma. Cancer Sci. 2019, 110, 3695-3707. [CrossRef] [PubMed]

143. Xu, L.; Tang, H.; Wang, K.; Zheng, Y.; Feng, J.; Dong, H.; Jin, Y.; Cao, C.; Chen, X.; Gao, G. Pharmacological inhibition of EZH2 combined with DNA-damaging agents interferes with the DNA damage response in MM cells. Mol. Med. Rep. 2019, 19, $4249-4255$. [CrossRef] [PubMed]

144. Yu, T.; Du, C.; Ma, X.; Sui, W.; Yu, Z.; Liu, L.; Zhao, L.; Li, Z.; Xu, J.; Wei, X.; et al. Polycomb-like Protein 3 Induces Proliferation and Drug Resistance in Multiple Myeloma and Is Regulated by miRNA-15a. Mol. Cancer Res. 2020, 18, 1063-1073. [CrossRef] [PubMed]

145. Momparler, R.L.; Côté, S.; Momparler, L.F.; Idaghdour, Y. Inhibition of DNA and Histone Methylation by 5-Aza-2'-Deoxycytidine (Decitabine) and 3-Deazaneplanocin-A on Antineoplastic Action and Gene Expression in Myeloid Leukemic Cells. Front. Oncol. 2017, 7. [CrossRef]

146. Chapman, M.A.; Lawrence, M.S.; Keats, J.; Cibulskis, K.; Sougnez, C.; Schinzel, A.C.; Harview, C.; Brunet, J.-P.; Ahmann, G.J.; Adli, M.; et al. Initial genome sequencing and analysis of multiple myeloma. Nature 2011, 471, 467-472. [CrossRef] 
147. Cerveira, N.; Correia, C.; Dória, S.; Bizarro, S.D.C.; Rocha, P.; Gomes, P.; Torres, L.; Norton, L.; Borges, B.S.; Castedo, S.; et al. Frequency of NUP98-NSD1 fusion transcript in childhood acute myeloid leukaemia. Leukemia 2003, 17, 2244-2247. [CrossRef] [PubMed]

148. Wang, G.G.; Cai, L.; Pasillas, M.P.; Kamps, M.P. NUP98-NSD1 links H3K36 methylation to Hox-A gene activation and leukaemogenesis. Nature 2007, 9, 804-812. [CrossRef]

149. Oyer, J.A.; Huang, X.; Zheng, Y.; Shim, J.; Ezponda, T.; Carpenter, Z.; Allegretta, M.; Okot-Kotber, C.I.; Patel, J.P.; Melnick, A.; et al. Point mutation E1099K in MMSET/NSD2 enhances its methyltranferase activity and leads to altered global chromatin methylation in lymphoid malignancies. Leukemia 2013, 28, 198-201. [CrossRef]

150. Keats, J.; Reiman, T.; Maxwell, C.; Taylor, B.J.; Larratt, L.M.; Mant, M.J.; Belch, A.R.; Pilarski, L.M. In multiple myeloma $\mathrm{t}(4 ; 14)(\mathrm{p} 16 ; \mathrm{q} 32)$ is an adverse prognostic factor irrespective of FGFR3 expression. Blood 2003, 101, 1520-1529. [CrossRef]

151. Kuo, A.J.; Cheung, P.; Chen, K.; Zee, B.; Kioi, M.; Lauring, J.; Xi, Y.; Park, B.H.; Shi, X.; Garcia, B.A.; et al. NSD2 Links Dimethylation of Histone H3 at Lysine 36 to Oncogenic Programming. Mol. Cell 2011, 44, 609-620. [CrossRef] [PubMed]

152. Martinez-Garcia, E.; Popovic, R.; Min, D.-J.; Sweet, S.; Thomas, P.; Zamdborg, L.; Heffner, A.; Will, C.; Lamy, L.; Staudt, L.M.; et al. The MMSET histone methyl transferase switches global histone methylation and alters gene expression in $\mathrm{t}(4 ; 14) \mathrm{multiple}$ myeloma cells. Blood 2011, 117, 211-220. [CrossRef] [PubMed]

153. Popovic, R.; Martinez-Garcia, E.; Giannopoulou, E.G.; Zhang, Q.; Zhang, Q.; Ezponda, T.; Shah, M.Y.; Zheng, Y.; Will, C.M.; Small, E.C.; et al. Histone Methyltransferase MMSET/NSD2 Alters EZH2 Binding and Reprograms the Myeloma Epigenome through Global and Focal Changes in H3K36 and H3K27 Methylation. PLoS Genet. 2014, 10, e1004566. [CrossRef]

154. An The Cancer Genome Atlas Research Network Genomic and Epigenomic Landscapes of Adult De Novo Acute Myeloid Leukemia. N. Engl. J. Med. 2013, 368, 2059-2074. [CrossRef] [PubMed]

155. Metzeler, K.H.; Herold, T.; Rothenberg-Thurley, M.; Amler, S.; Sauerland, M.C.; Görlich, D.; Schneider, S.; Konstandin, N.P.; Dufour, A.; Bräundl, K.; et al. Spectrum and prognostic relevance of driver gene mutations in acute myeloid leukemia. Blood 2016, 128, 686-698. [CrossRef] [PubMed]

156. van Haaften, G.; Dalgliesh, G.L.; Davies, H.; Chen, L.; Bignell, G.; Greenman, C.; Edkins, S.; Hardy, C.; O’Meara, S.; Teague, J.; et al. Somatic mutations of the histone H3K27 demethylase gene UTX in human cancer. Nat. Genet. 2009, 41, 521-523. [CrossRef] [PubMed]

157. Gozdecka, M.; Meduri, E.; Mazan, M.; Tzelepis, K.; Dudek, M.; Knights, A.J.; Pardo, M.; Yu, L.; Choudhary, J.; Metzakopian, E.; et al. UTX-mediated enhancer and chromatin remodeling suppresses myeloid leukemogenesis through noncatalytic inverse regulation of ETS and GATA programs. Nat. Genet. 2018, 50, 883-894. [CrossRef] [PubMed]

158. Ezponda, T.; Popovic, R.; Zheng, Y.; Nabet, B.; Will, M.C.; Small, E.C.; Occhionorelli, M.; Tonon, M.G.; Keats, J.J.; Kelleher, N.L.; et al. Loss of the Histone Demethylase UTX Contributes to Multiple Myeloma and Sensitizes Cells to EZH2 Inhibitors. Blood 2014, 124, 611. [CrossRef]

159. Lee, M.G.; Villa, R.; Trojer, P.; Norman, J.; Yan, K.-P.; Reinberg, D.; Di Croce, L.; Shiekhattar, R. Demethylation of H3K27 Regulates Polycomb Recruitment and H2A Ubiquitination. Science 2007, 318, 447-450. [CrossRef]

160. Sze, C.C.; Shilatifard, A. MLL3/MLL4/COMPASS Family on Epigenetic Regulation of Enhancer Function and Cancer. Cold Spring Harb. Perspect. Med. 2016, 6, a026427. [CrossRef]

161. Wei, X.; Calvo-Vidal, M.N.; Chen, S.; Wu, G.; Revuelta, M.V.; Sun, J.; Zhang, J.; Walsh, M.F.; Nichols, K.E.; Joseph, V.; et al Germline Lysine-Specific Demethylase 1 (LSD1/KDM1A) Mutations Confer Susceptibility to Multiple Myeloma. Cancer Res. 2018, 78, 2747-2759. [CrossRef]

162. Mithraprabhu, S.; Kalff, A.; Chow, A.; Khong, T.; Spencer, A. Dysregulated Class I histone deacetylases are indicators of poor prognosis in multiple myeloma. Epigenetics 2014, 9, 1511-1520. [CrossRef] [PubMed]

163. Cea, M.; Cagnetta, A.; Adamia, S.; Acharya, C.; Tai, Y.-T.; Fulciniti, M.; Ohguchi, H.; Munshi, A.; Acharya, P.; Bhasin, M.K.; et al. Evidence for a role of the histone deacetylase SIRT6 in DNA damage response of multiple myeloma cells. Blood 2016, 127, 1138-1150. [CrossRef] [PubMed]

164. Cagnetta, A.; Soncini, D.; Orecchioni, S.; Talarico, G.; Minetto, P.; Guolo, F.; Retali, V.; Colombo, N.; Carminati, E.; Clavio, M.; et al. Depletion of SIRT6 enzymatic activity increases acute myeloid leukemia cells' vulnerability to DNA-damaging agents. Haematologica 2017, 103, 80-90. [CrossRef]

165. Ordoñez, R.; Kulis, M.; Russiñol, N.; Chapaprieta, V.; Carrasco-Leon, A.; García-Torre, B.; Charalampopoulou, S.; Clot, G.; Beekman, R.; Meydan, C.; et al. Chromatin activation as a unifying principle underlying pathogenic mechanisms in multiple myeloma. Genome Res. 2020, 30, 1217-1227. [CrossRef]

166. Imai, Y.; Hirano, M.; Kobayashi, M.; Futami, M.; Tojo, A. HDAC Inhibitors Exert Anti-Myeloma Effects through Multiple Modes of Action. Cancers 2019, 11, 475. [CrossRef]

167. Hansen, V.L.; Coleman, M.; Elkins, S.; Letzer, J.P.; Levy, M.Y.; Seneviratne, L.; Rine, J.; White, M.; Kuriakose, E.T. An Expanded Treatment Protocol of Panobinostat Plus Bortezomib and Dexamethasone in Patients With Previously Treated Myeloma. Clin. Lymphoma Myeloma Leuk. 2018, 18, 400-407.e1. [CrossRef]

168. Han, Z.; Rosen, S.T.; Querfeld, C. Targeting microRNA in hematologic malignancies. Curr. Opin. Oncol. 2020, 32, 535-544. [CrossRef] 
169. Katsaraki, K.; Karousi, P.; Artemaki, P.; Scorilas, A.; Pappa, V.; Kontos, C.; Papageorgiou, S. MicroRNAs: Tiny Regulators of Gene Expression with Pivotal Roles in Normal B-Cell Development and B-Cell Chronic Lymphocytic Leukemia. Cancers 2021, 13, 593. [CrossRef]

170. Marton, S.; Garcia, M.R.; Robello, C.; Persson, H.; Trajtenberg, F.; Pritsch, O.; Rovira, C.; Naya, H.; Dighiero, G.; Cayota, A. Small RNAs analysis in CLL reveals a deregulation of miRNA expression and novel miRNA candidates of putative relevance in CLL pathogenesis. Leukemia 2007, 22, 330-338. [CrossRef] [PubMed]

171. Zanette, D.; Rivadavia, F.; Molfetta, G.; Barbuzano, F.; Proto-Siqueira, R.; Falcão, R.; Zago, M.; Silva, W., Jr. miRNA expression profiles in chronic lymphocytic and acute lymphocytic leukemia. Braz. J. Med. Biol. Res. 2007, 40, 1435-1440. [CrossRef]

172. Alzrigat, M.; Atienza-Párraga, A.; Agarwal, P.; Zureigat, H.; Österborg, A.; Nahi, H.; Ma, A.; Jin, J.; Nilsson, K.; Öberg, F.; et al. EZH2 inhibition in multiple myeloma downregulates myeloma associated oncogenes and upregulates microRNAs with potential tumor suppressor functions. Oncotarget 2016, 8, 10213-10224. [CrossRef]

173. Fulci, V.; Chiaretti, S.; Goldoni, M.; Azzalin, G.; Carucci, N.; Tavolaro, S.; Castellano, L.; Magrelli, A.; Citarella, F.; Messina, M.; et al. Quantitative technologies establish a novel microRNA profile of chronic lymphocytic leukemia. Blood 2007, 109, 4944-4951. [CrossRef] [PubMed]

174. Stamatopoulos, B.; Meuleman, N.; Haibe-Kains, B.; Saussoy, P.; Neste, E.V.D.; Michaux, L.; Heimann, P.; Martiat, P.; Bron, D.; Lagneaux, L. microRNA-29c and microRNA-223 down-regulation has in vivo significance in chronic lymphocytic leukemia and improves disease risk stratification. Blood 2009, 113, 5237-5245. [CrossRef]

175. Rossi, S.; Shimizu, M.; Barbarotto, E.; Nicoloso, M.S.; Dimitri, F.; Sampath, D.; Fabbri, M.; Lerner, S.; Barron, L.L.; Rassenti, L.Z.; et al. microRNA fingerprinting of CLL patients with chromosome 17p deletion identify a miR-21 score that stratifies early survival. Blood 2010, 116, 945-952. [CrossRef]

176. Gutierrez, N.; Sarasquete, M.E.; Misiewicz-Krzeminska, I.; Delgado, M.; Rivas, J.D.L.; Ticona, F.V.; Fermiñán, E.; Martín-Jiménez, P.; Chillon, M.C.; Risueño, A.; et al. Deregulation of microRNA expression in the different genetic subtypes of multiple myeloma and correlation with gene expression profiling. Leukemia 2010, 24, 629-637. [CrossRef]

177. Chi, J.; Ballabio, E.; Chen, X.-H.; Kušec, R.; Taylor, S.; Hay, D.; Tramonti, D.; Saunders, N.J.; Littlewood, T.; Pezzella, F.; et al. MicroRNA expression in multiple myeloma is associated with genetic subtype, isotype and survival. Biol. Direct $2011,6,23$. [CrossRef]

178. Kassambara, A.; Jourdan, M.; Bruyer, A.; Robert, N.; Pantesco, V.; Elemento, O.; Klein, B.; Moreaux, J. Global miRNA expression analysis identifies novel key regulators of plasma cell differentiation and malignant plasma cell. Nucleic Acids Res. 2017, 45, 5639-5652. [CrossRef]

179. Eis, P.; Tam, W.; Sun, L.; Chadburn, A.; Li, Z.; Gomez, M.F.; Lund, E.; Dahlberg, J.E. Accumulation of miR-155 and BIC RNA in human B cell lymphomas. Proc. Natl. Acad. Sci. USA 2005, 102, 3627-3632. [CrossRef] [PubMed]

180. Fava, P.; Bergallo, M.; Astrua, C.; Brizio, M.; Galliano, I.; Montanari, P.; Daprà, V.; Novelli, M.; Savoia, P.; Quaglino, P.; et al. miR-155 expression in Primary Cutaneous T-Cell Lymphomas (CTCL). J. Eur. Acad. Dermatol. Venereol. 2016, 31, e27-e29. [CrossRef] [PubMed]

181. Moyal, L.; Barzilai, A.; Gorovitz, B.; Hirshberg, A.; Amariglio, N.; Jacob-Hirsch, J.; Maron, L.; Feinmesser, M.; Hodak, E. miR-155 is involved in tumor progression of mycosis fungoides. Exp. Dermatol. 2013, 22, 431-433. [CrossRef]

182. Gerloff, D.; Grundler, R.; Wurm, A.A.; Bräuer-Hartmann, D.; Katzerke, C.; Hartmann, J.-U.; Madan, V.; Müller-Tidow, C.; Duyster, J.; Tenen, D.G.; et al. NF-kB/STAT5/miR-155 network targets PU.1 in FLT3-ITD-driven acute myeloid leukemia. Leukemia 2014, 29, 535-547. [CrossRef] [PubMed]

183. Palma, C.A.; Al Sheikha, D.; Lim, T.K.; Bryant, A.; Vu, T.T.; Jayaswal, V.; Ma, D.D.F. MicroRNA-155 as an inducer of apoptosis and cell differentiation in Acute Myeloid Leukaemia. Mol. Cancer 2014, 13, 79. [CrossRef] [PubMed]

184. Ferrajoli, A.; Shanafelt, T.D.; Ivan, C.; Shimizu, M.; Rabe, K.G.; Nouraee, N.; Ikuo, M.; Ghosh, A.K.; Lerner, S.; Rassenti, L.Z.; et al. Prognostic value of miR-155 in individuals with monoclonal B-cell lymphocytosis and patients with B chronic lymphocytic leukemia. Blood 2013, 122, 1891-1899. [CrossRef]

185. Lawrie, C.H.; Soneji, S.; Marafioti, T.; Cooper, C.D.; Palazzo, S.; Paterson, J.C.; Cattan, H.; Enver, T.; Mager, R.; Boultwood, J.; et al. Microrna expression distinguishes between germinal center B cell-like and activated B cell-like subtypes of diffuse large B cell lymphoma. Int. J. Cancer 2007, 121, 1156-1161. [CrossRef]

186. Mi, S.; Li, Z.; Chen, P.; He, C.; Cao, D.; Elkahloun, A.; Lu, J.; Pelloso, L.A.; Wunderlich, M.; Huang, H.; et al. Aberrant overexpression and function of the miR-17-92 cluster in MLL-rearranged acute leukemia. Proc. Natl. Acad. Sci. USA 2010, 107, 3710-3715. [CrossRef]

187. Poláková, K.M.; Lopotová, T.; Klamová, H.; Burda, P.; Trněný, M.; Stopka, T.; Moravcová, J. Expression patterns of microRNAs associated with CML phases and their disease related targets. Mol. Cancer 2011, 10, 41. [CrossRef] [PubMed]

188. Garzon, R.; Pichiorri, F.; Palumbo, T.; Visentini, M.; Aqeilan, R.; Cimmino, A.; Wang, H.; Sun, H.; Volinia, S.; Alder, H.; et al. MicroRNA gene expression during retinoic acid-induced differentiation of human acute promyelocytic leukemia. Oncogene 2007, 26, 4148-4157. [CrossRef]

189. Akao, Y.; Nakagawa, Y.; Kitade, Y.; Kinoshita, T.; Naoe, T. Downregulation of microRNAs-143 and -145 in B-cell malignancies. Cancer Sci. 2007, 98, 1914-1920. [CrossRef]

190. Chen, C.-Z.; Li, L.; Lodish, H.F.; Bartel, D.P. MicroRNAs Modulate Hematopoietic Lineage Differentiation. Science 2004, 303, 83-86. [CrossRef] [PubMed] 
191. Debernardi, S.; Skoulakis, S.; Molloy, G.; Chaplin, T.; Dixon-McIver, A.; Young, B.D. MicroRNA miR-181a correlates with morphological sub-class of acute myeloid leukaemia and the expression of its target genes in global genome-wide analysis. Leukemia 2007, 21, 912-916. [CrossRef]

192. Li, Z.; Lu, J.; Sun, M.; Mi, S.; Zhang, H.; Luo, R.T.; Chen, P.; Wang, Y.; Yan, M.; Qian, Z.; et al. Distinct microRNA expression profiles in acute myeloid leukemia with common translocations. Proc. Natl. Acad. Sci. USA 2008, 105, 15535-15540. [CrossRef]

193. Wang, Z.; Luo, H.; Fang, Z.; Fan, Y.; Liu, X.; Zhang, Y.; Rui, S.; Chen, Y.; Hong, L.; Zhang, J.J.G.M.; et al. MiR-204 acts as a potential therapeutic target in acute myeloid leukemia by increasing BIRC6-mediated apoptosis. BMB Rep. 2018, 51, 444-449. [CrossRef] [PubMed]

194. Wang, Z.; Fang, Z.; Lu, R.; Zhao, H.; Gong, T.; Liu, D.; Hong, L.; Ma, J.; Zhang, M. MicroRNA-204 Potentiates the Sensitivity of Acute Myeloid Leukemia Cells to Arsenic Trioxide. Oncol. Res. Featur. Preclin. Clin. Cancer Ther. 2019, 27, 1035-1042. [CrossRef]

195. Wang, Y.; Tang, P.; Chen, Y.; Chen, J.; Ma, R.; Sun, L. Overexpression of microRNA-125b inhibits human acute myeloid leukemia cells invasion, proliferation and promotes cells apoptosis by targeting NF- $\mathrm{B}$ signaling pathway. Biochem. Biophys. Res. Commun. 2017, 488, 60-66. [CrossRef]

196. Shen, M.Y.; Wang, Y.; Cui, S.Y.; Wu, X.L.; Guo, Y.; Xu, R.R. MicroRNA-125a Regulates Proliferation and Apoptosis of Acute Myeloid Leukemia through Targeting NF-KB Pathway. Eur. Rev. Med. Pharmacol. Sci. 2019, 23, 3594-3601. [CrossRef]

197. Gañán-Gómez, I.; Wei, Y.; Yang, H.; Pierce, S.; Bueso-Ramos, C.; Calin, G.; Boyano-Adánez, M.D.C.; García-Manero, G. Overexpression of miR-125a in Myelodysplastic Syndrome CD34+ Cells Modulates NF-kB Activation and Enhances Erythroid Differentiation Arrest. PLoS ONE 2014, 9, e93404. [CrossRef] [PubMed]

198. Allegra, A.; Innao, V.; Gerace, D.; Bianco, O.; Musolino, C. The metabolomic signature of hematologic malignancies. Leuk. Res. 2016, 49, 22-35. [CrossRef] [PubMed]

199. Stratton, M.R.; Campbell, P.J.; Futreal, P.A. The Cancer Genome. Nature 2009, 458, 719-724. [CrossRef]

200. Pavlova, N.; Thompson, C.B. The Emerging Hallmarks of Cancer Metabolism. Cell Metab. 2016, 23, 27-47. [CrossRef]

201. Zhang, Y.; Liu, Y.; Xu, X. Knockdown of LncRNA-UCA1 suppresses chemoresistance of pediatric AML by inhibiting glycolysis through the microRNA-125a/hexokinase 2 pathway. J. Cell. Biochem. 2018, 119, 6296-6308. [CrossRef] [PubMed]

202. English, S.G.; Hadj-Moussa, H.; Storey, K.B. MicroRNAs regulate survival in oxygen-deprived environments. J. Exp. Biol. 2018, 221, jeb.190579. [CrossRef] [PubMed]

203. Ikeda, S.; Kitadate, A.; Abe, F.; Takahashi, N.; Tagawa, H. Hypoxia-inducible KDM3A addiction in multiple myeloma. Blood Adv. 2018, 2, 323-334. [CrossRef] [PubMed]

204. Abdollahi, P.; Vandsemb, E.N.; Elsaadi, S.; Røst, L.M.; Yang, R.; Hjort, M.A.; Andreassen, T.; Misund, K.; Slørdahl, T.S.; Rø, T.B.; et al. Phosphatase of regenerating liver-3 regulates cancer cell metabolism in multiple myeloma. FASEB J. 2021, 35, e21344. [CrossRef]

205. Vandsemb, E.N.; Rye, M.B.; Steiro, I.J.; Elsaadi, S.; Rø, T.B.; Slørdahl, T.S.; Sponaas, A.; Børset, M.; Abdollahi, P. PRL-3 induces a positive signaling circuit between glycolysis and activation of STAT1/2. FEBS J. 2021. [CrossRef]

206. Caillot, M.; Bourgeais, J.; Dakik, H.; Costé, E.; Mazure, N.M.; Lelievre, E.; Coqueret, O.; Hérault, O.; Mazurier, F.; Sola, B. Cyclin D1 targets hexokinase 2 to control aerobic glycolysis in myeloma cells. Oncogenesis 2020, 9, 1-13. [CrossRef]

207. Ju, H.-Q.; Zhan, G.; Huang, A.; Sun, Y.; Wen, S.; Yang, J.; Lu, W.-H.; Xu, R.-H.; Li, J.; Li, Y.; et al. ITD mutation in FLT3 tyrosine kinase promotes Warburg effect and renders therapeutic sensitivity to glycolytic inhibition. Leukemia 2017, 31, 2143-2150. [CrossRef]

208. Ryu, M.J.; Han, J.; Kim, S.J.; Lee, M.J.; Ju, X.; Lee, Y.L.; Son, J.H.; Cui, J.; Jang, Y.; Chung, W.; et al. PTEN/AKT signaling mediates chemoresistance in refractory acute myeloid leukemia through enhanced glycolysis. Oncol. Rep. 2019, 42, 2149-2158. [CrossRef]

209. Saito, Y.; Chapple, R.H.; Lin, A.; Kitano, A.; Nakada, D. AMPK Protects Leukemia-Initiating Cells in Myeloid Leukemias from Metabolic Stress in the Bone Marrow. Cell Stem Cell 2015, 17, 585-596. [CrossRef]

210. Palomero, T.; Sulis, M.L.; Cortina, M.; Real, P.; Barnes, K.; Ciofani, M.; Caparros, E.; Buteau, J.; Brown, K.; Perkins, S.L.; et al. Mutational loss of PTEN induces resistance to NOTCH1 inhibition in T-cell leukemia. Nat. Med. 2007, 13, 1203-1210. [CrossRef]

211. Kishton, R.J.; Barnes, C.E.; Nichols, A.G.; Cohen, S.; Gerriets, V.; Siska, P.J.; Macintyre, A.; Goraksha-Hicks, P.; de Cubas, A.A.; Liu, T.; et al. AMPK Is Essential to Balance Glycolysis and Mitochondrial Metabolism to Control T-ALL Cell Stress and Survival. Cell Metab. 2016, 23, 649-662. [CrossRef]

212. Karagianni, P.; Giannouli, S.; Voulgarelis, M. From the (Epi)Genome to Metabolism and Vice Versa; Examples from Hematologic Malignancy. Int. J. Mol. Sci. 2021, 22, 6321. [CrossRef]

213. Rashkovan, M.; Ferrando, A. Metabolic dependencies and vulnerabilities in leukemia. Genes Dev. 2019, 33, 1460-1474. [CrossRef] [PubMed]

214. Jones, R.G.; Thompson, C.B. Tumor suppressors and cell metabolism: A recipe for cancer growth. Genes Dev. 2009, 23, 537-548. [CrossRef]

215. Nagao, A.; Kobayashi, M.; Koyasu, S.; Chow, C.C.T.; Harada, H. HIF-1-Dependent Reprogramming of Glucose Metabolic Pathway of Cancer Cells and Its Therapeutic Significance. Int. J. Mol. Sci. 2019, 20, 238. [CrossRef]

216. Jang, M.; Kim, S.S.; Lee, J. Cancer cell metabolism: Implications for therapeutic targets. Exp. Mol. Med. 2013, 45, e45. [CrossRef]

217. Shehata, M.; Schnabl, S.; Demirtas, D.; Hilgarth, M.; Hubmann, R.; Ponath, E.; Badrnya, S.; Lehner, C.; Hoelbl, A.; Duechler, M.; et al. Reconstitution of PTEN activity by CK2 inhibitors and interference with the PI3-K/Akt cascade counteract the antiapoptotic effect of human stromal cells in chronic lymphocytic leukemia. Blood 2010, 116, 2513-2521. [CrossRef] 
218. Cui, L.; Cheng, Z.; Liu, Y.; Dai, Y.; Pang, Y.; Jiao, Y.; Ke, X.; Cui, W.; Zhang, Q.; Shi, J.; et al. Overexpression of PDK2 and PDK3 reflects poor prognosis in acute myeloid leukemia. Cancer Gene Ther. 2018, 27, 15-21. [CrossRef]

219. Weisberg, E.; Banerji, L.; Wright, R.D.; Barrett, R.; Ray, A.; Moreno, D.; Catley, L.; Jiang, J.; Hall-Meyers, E.; Sauveur-Michel, M.; et al. Potentiation of antileukemic therapies by the dual PI3K/PDK-1 inhibitor, BAG956: Effects on BCR-ABL- and mutant FLT3-expressing cells. Blood 2008, 111, 3723-3734. [CrossRef] [PubMed]

220. Dang, C.V.; O’Donnell, K.A.; Zeller, K.I.; Nguyen, T.; Osthus, R.C.; Li, F. The c-Myc target gene network. Semin. Cancer Biol. 2006, 16, 253-264. [CrossRef] [PubMed]

221. Dang, C.V.; Kim, J.-W.; Gao, P.; Yustein, J. The interplay between MYC and HIF in cancer. Nat. Rev. Cancer 2008, 8, 51-56. [CrossRef]

222. Somers, K.; Wen, V.W.; Middlemiss, S.M.C.; Osborne, B.; Forgham, H.; Jung, M.; Karsa, M.; Clifton, M.; Bongers, A.; Gao, J.; et al. A novel small molecule that kills a subset of MLL-rearranged leukemia cells by inducing mitochondrial dysfunction. Oncogene 2019, 38, 3824-3842. [CrossRef] [PubMed]

223. Viziteu, E.; Grandmougin, C.; Goldschmidt, H.; Seckinger, A.; Hose, D.; Klein, B.; Moreaux, J. Chetomin, targeting HIF-1 $\alpha /$ p300 complex, exhibits antitumour activity in multiple myeloma. Br. J. Cancer 2016, 114, 519-523. [CrossRef] [PubMed]

224. Huang, W.-L.; Abudureheman, T.; Xia, J.; Chu, L.; Zhou, H.; Zheng, W.-W.; Zhou, N.; Shi, R.-Y.; Li, M.-H.; Zhu, J.-M.; et al. CDK9 Inhibitor Induces the Apoptosis of B-Cell Acute Lymphocytic Leukemia by Inhibiting c-Myc-Mediated Glycolytic Metabolism. Front. Cell Dev. Biol. 2021, 9. [CrossRef]

225. De Rosa, V.; Monti, M.; Terlizzi, C.; Fonti, R.; Del Vecchio, S.; Iommelli, F. Coordinate Modulation of Glycolytic Enzymes and OXPHOS by Imatinib in BCR-ABL Driven Chronic Myelogenous Leukemia Cells. Int. J. Mol. Sci. 2019, 20, 3134. [CrossRef] [PubMed]

226. Matsumoto, T.; Jimi, S.; Migita, K.; Takamatsu, Y.; Hara, S. Inhibition of glucose transporter 1 induces apoptosis and sensitizes multiple myeloma cells to conventional chemotherapeutic agents. Leuk. Res. 2015, 41, 103-110. [CrossRef]

227. Åbacka, H.; Hansen, J.S.; Huang, P.; Venskutonyte, R.; Hyrenius-Wittsten, A.; Poli, G.; Tuccinardi, T.; Granchi, C.; Minutolo, F.; Hagström-Andersson, A.K.; et al. Targeting GLUT1 in acute myeloid leukemia to overcome cytarabine resistance. Haematologica 2020, 106, 1163-1166. [CrossRef]

228. McBrayer, S.K.; Cheng, J.C.; Singhal, S.; Krett, N.L.; Rosen, S.T.; Shanmugam, M. Multiple myeloma exhibits novel dependence on GLUT4, GLUT8, and GLUT11: Implications for glucose transporter-directed therapy. Blood 2012, 119, 4686-4697. [CrossRef] [PubMed]

229. Chen, W.-L.; Wang, Y.-Y.; Zhao, A.; Xia, L.; Xie, G.; Su, M.; Zhao, L.; Liu, J.; Qu, C.; Wei, R.; et al. Enhanced Fructose Utilization Mediated by SLC2A5 Is a Unique Metabolic Feature of Acute Myeloid Leukemia with Therapeutic Potential. Cancer Cell 2016, 30, 779-791. [CrossRef]

230. Robinson, A.J.; Hopkins, G.L.; Rastogi, N.; Hodges, M.; Doyle, M.; Davies, S.; Hole, P.S.; Omidvar, N.; Darley, R.L.; Tonks, A. Reactive Oxygen Species Drive Proliferation in Acute Myeloid Leukemia via the Glycolytic Regulator PFKFB3. Cancer Res. 2019, 80, 937-949. [CrossRef]

231. Hulleman, E.; Kazemier, K.M.; Holleman, A.; VanderWeele, D.; Rudin, C.; Broekhuis, M.J.C.; Evans, W.E.; Pieters, R.; Boer, M.D. Inhibition of glycolysis modulates prednisolone resistance in acute lymphoblastic leukemia cells. Blood 2009, 113, $2014-2021$. [CrossRef]

232. Hanson, D.J.; Nakamura, S.; Amachi, R.; Hiasa, M.; Oda, A.; Tsuji, D.; Itoh, K.; Harada, T.; Horikawa, K.; Teramachi, J.; et al. Effective impairment of myeloma cells and their progenitors by blockade of monocarboxylate transportation. Oncotarget 2015, 6, 33568-33586. [CrossRef] [PubMed]

233. Lagadinou, E.D.; Sach, A.; Callahan, K.; Rossi, R.M.; Neering, S.J.; Minhajuddin, M.; Ashton, J.; Pei, S.; Grose, V.; O’Dwyer, K.M.; et al. BCL-2 Inhibition Targets Oxidative Phosphorylation and Selectively Eradicates Quiescent Human Leukemia Stem Cells. Cell Stem Cell 2013, 12, 329-341. [CrossRef] [PubMed]

234. Jones, C.L.; Stevens, B.M.; D’Alessandro, A.; Reisz, J.A.; Culp-Hill, R.; Nemkov, T.; Pei, S.; Khan, N.; Adane, B.; Ye, H.; et al. Inhibition of Amino Acid Metabolism Selectively Targets Human Leukemia Stem Cells. Cancer Cell 2018, 34, 724-740.e4. [CrossRef] [PubMed]

235. Chen, C.; Hao, X.; Lai, X.; Liu, L.; Zhu, J.; Shao, H.; Huang, D.; Gu, H.; Zhang, T.; Yu, Z.; et al. Oxidative phosphorylation enhances the leukemogenic capacity and resistance to chemotherapy of B cell acute lymphoblastic leukemia. Sci. Adv. 2021, 7, eabd6280. [CrossRef] [PubMed]

236. Kuntz, E.M.; Baquero, P.; Michie, A.; Dunn, K.; Tardito, S.; Holyoake, T.L.; Helgason, G.V.; Gottlieb, E. Targeting mitochondrial oxidative phosphorylation eradicates therapy-resistant chronic myeloid leukemia stem cells. Nat. Med. 2017, 23, 1234-1240. [CrossRef] [PubMed]

237. da Silva-Diz, V.; Cao, B.; Lancho, O.; Chiles, E.; Alasadi, A.; Aleksandrova, M.; Luo, S.; Singh, A.; Tao, H.; Augeri, D.J.; et al. A novel and highly effective mitochondrial uncoupling drug in T-cell leukemia. Blood 2021. [CrossRef]

238. Jitschin, R.; Hofmann, A.D.; Bruns, H.; Gießl, A.; Bricks, J.; Berger, J.; Saul, D.; Eckart, M.J.; Mackensen, A.; Mougiakakos, D. Mitochondrial metabolism contributes to oxidative stress and reveals therapeutic targets in chronic lymphocytic leukemia. Blood 2014, 123, 2663-2672. [CrossRef] 
239. Marlein, C.R.; Piddock, R.E.; Mistry, J.J.; Zaitseva, L.; Hellmich, C.; Horton, R.H.; Zhou, Z.; Auger, M.J.; Bowles, K.M.; Rushworth, S.A. CD38-Driven Mitochondrial Trafficking Promotes Bioenergetic Plasticity in Multiple Myeloma. Cancer Res. 2019, 79, 2285-2297. [CrossRef]

240. Xiang, Y.; Fang, B.; Liu, Y.; Yan, S.; Cao, D.; Mei, H.; Wang, Q.; Hu, Y.; Guo, T. SR18292 exerts potent antitumor effects in multiple myeloma via inhibition of oxidative phosphorylation. Life Sci. 2020, 256, 117971. [CrossRef]

241. Kaelin, W.G.; McKnight, S.L. Influence of Metabolism on Epigenetics and Disease. Cell 2013, 153, 56-69. [CrossRef]

242. Wang, J.; Ye, W.; Yan, X.; Guo, Q.; Ma, Q.; Lin, F.; Huang, J.; Jin, J. Low expression of ACLY associates with favorable prognosis in acute myeloid leukemia. J. Transl. Med. 2019, 17, 149. [CrossRef]

243. Comerford, S.A.; Huang, Z.; Du, X.; Wang, Y.; Cai, L.; Witkiewicz, A.K.; Walters, H.; Tantawy, M.N.; Fu, A.; Manning, H.C.; et al. Acetate Dependence of Tumors. Cell 2014, 159, 1591-1602. [CrossRef]

244. Kim, J.-A.; Yeom, Y.I. Metabolic Signaling to Epigenetic Alterations in Cancer. Biomol. Ther. 2018, 26, 69-80. [CrossRef]

245. Li, Z.; Liu, H.; He, J.; Wang, Z.; Yin, Z.; You, G.; Wang, Z.; Davis, R.E.; Lin, P.; Bergsagel, P.L.; et al. Acetyl-CoA Synthetase 2: A Critical Linkage in Obesity-Induced Tumorigenesis in Myeloma. Cell Metab. 2021, 33, 78-93.e7. [CrossRef] [PubMed]

246. Le, A.; Lane, A.N.; Hamaker, M.; Bose, S.; Gouw, A.; Barbi, J.; Tsukamoto, T.; Rojas, C.J.; Slusher, B.S.; Zhang, H.; et al. GlucoseIndependent Glutamine Metabolism via TCA Cycling for Proliferation and Survival in B Cells. Cell Metab. 2012, 15, 110-121. [CrossRef]

247. Miwa, H.; Shikami, M.; Goto, M.; Mizuno, S.; Takahashi, M.; Tsunekawa-Imai, N.; Ishikawa, T.; Mizutani, M.; Horio, T.; Gotou, M.; et al. Leukemia cells demonstrate a different metabolic perturbation provoked by 2-deoxyglucose. Oncol. Rep. 2013, 29, 2053-2057. [CrossRef] [PubMed]

248. Yen, K.; Travins, J.; Wang, F.; David, M.; Artin, E.; Straley, K.; Padyana, A.; Gross, S.; DelaBarre, B.; Tobin, E.; et al. AG-221, a First-in-Class Therapy Targeting Acute Myeloid Leukemia Harboring Oncogenic IDH2 Mutations. Cancer Discov. 2017, 7 , 478-493. [CrossRef] [PubMed]

249. Rizzieri, D.; Paul, B.; Kang, Y. Metabolic alterations and the potential for targeting metabolic pathways in the treatment of multiple myeloma. J. Cancer Metastasis Treat. 2019, 2019. [CrossRef] [PubMed]

250. Dyczynski, M.; Vesterlund, M.; Björklund, A.-C.; Zachariadis, V.; Janssen, J.; Gallart-Ayala, H.; Daskalaki, E.; Wheelock, C.E.; Lehtiö, J.; Grandér, D.; et al. Metabolic reprogramming of acute lymphoblastic leukemia cells in response to glucocorticoid treatment. Cell Death Dis. 2018, 9, 1-13. [CrossRef] [PubMed]

251. Bajpai, R.; Matulis, S.M.; Wei, C.; Nooka, A.K.; Von Hollen, H.E.; Lonial, S.; Boise, L.; Shanmugam, M. Targeting glutamine metabolism in multiple myeloma enhances BIM binding to BCL-2 eliciting synthetic lethality to venetoclax. Oncogene 2015, 35, 3955-3964. [CrossRef]

252. Su, R.; Dong, L.; Li, C.; Nachtergaele, S.; Wunderlich, M.; Qing, Y.; Deng, X.; Wang, Y.; Weng, X.; Hu, C.; et al. R-2HG Exhibits Anti-tumor Activity by Targeting FTO/m6A/MYC/CEBPA Signaling. Cell 2017, 172, 90-105.e23. [CrossRef]

253. Qing, Y.; Dong, L.; Gao, L.; Li, C.; Li, Y.; Han, L.; Prince, E.; Tan, B.; Deng, X.; Wetzel, C.; et al. R-2-hydroxyglutarate attenuates aerobic glycolysis in leukemia by targeting the FTO/m6A/PFKP/LDHB axis. Mol. Cell 2021, 81, 922-939.e9. [CrossRef]

254. Elo, L.L.; Karjalainen, R.; Öhman, T.; Hintsanen, P.; Nyman, T.A.; Heckman, C.A.; Aittokallio, T. Statistical detection of quantitative protein biomarkers provides insights into signaling networks deregulated in acute myeloid leukemia. Proteomics 2014, 14, 2443-2453. [CrossRef] [PubMed]

255. Toro, J.R.; Nickerson, M.L.; Wei, M.-H.; Warren, M.B.; Glenn, G.M.; Turner, M.L.; Stewart, L.; Duray, P.; Tourre, O.; Sharma, N.; et al. Mutations in the Fumarate Hydratase Gene Cause Hereditary Leiomyomatosis and Renal Cell Cancer in Families in North America. Am. J. Hum. Genet. 2003, 73, 95-106. [CrossRef]

256. Baysal, B.E. A Recurrent Stop-Codon Mutation in Succinate Dehydrogenase Subunit B Gene in Normal Peripheral Blood and Childhood T-Cell Acute Leukemia. PLoS ONE 2007, 2, e436. [CrossRef] [PubMed]

257. Renella, R.; Carnevale, J.; Schneider, K.A.; Hornick, J.L.; Rana, H.Q.; Janeway, K.A. Exploring the association of succinate dehydrogenase complex mutations with lymphoid malignancies. Fam. Cancer 2014, 13, 507-511. [CrossRef] [PubMed]

258. Halpern, B.C.; Clark, B.R.; Hardy, D.N.; Halpern, R.M.; Smith, R.A. The Effect of Replacement of Methionine by Homocystine on Survival of Malignant and Normal Adult Mammalian Cells in Culture. Proc. Natl. Acad. Sci. USA 1974, 71, 1133-1136. [CrossRef]

259. Barve, A.; Vega, A.; Shah, P.P.; Ghare, S.; Casson, L.; Wunderlich, M.; Siskind, L.J.; Beverly, L.J. Perturbation of Methionine/Sadenosylmethionine Metabolism as a Novel Vulnerability in MLL Rearranged Leukemia. Cells 2019, 8, 1322. [CrossRef]

260. Bolzoni, M.; Chiu, M.; Accardi, F.; Vescovini, R.; Airoldi, I.; Storti, P.; Todoerti, K.; Agnelli, L.; Missale, G.; Andreoli, R.; et al. Dependence on glutamine uptake and glutamine addiction characterize myeloma cells: A new attractive target. Blood 2016, 128, 667-679. [CrossRef]

261. Rosilio, C.; Nebout, M.; Imbert, V.; Griessinger, E.; Neffati, Z.; Benadiba, J.; Hagenbeek, T.J.; Spits, H.; Reverso, J.; Ambrosetti, D.; et al. L-type amino-acid transporter 1 (LAT1): A therapeutic target supporting growth and survival of T-cell lymphoblastic lymphoma/T-cell acute lymphoblastic leukemia. Leukemia 2014, 29, 1253-1266. [CrossRef] [PubMed]

262. Fuchs, B.C.; Bode, B.P. Amino acid transporters ASCT2 and LAT1 in cancer: Partners in crime? Semin. Cancer Biol. 2005, 15, 254-266. [CrossRef]

263. Maddocks, O.; Labuschagne, C.F.; Adams, P.D.; Vousden, K.H. Serine Metabolism Supports the Methionine Cycle and DNA/RNA Methylation through De Novo ATP Synthesis in Cancer Cells. Mol. Cell 2016, 61, 210-221. [CrossRef] [PubMed] 
264. Elsaadi, S.; Steiro, I.; Abdollahi, P.; Vandsemb, E.N.; Yang, R.; Slørdahl, T.S.; Rø, T.B.; Menu, E.; Sponaas, A.-M.; Børset, M. Targeting phosphoglycerate dehydrogenase in multiple myeloma. Exp. Hematol. Oncol. 2021, 10, 1-13. [CrossRef] [PubMed]

265. Polet, F.; Corbet, C.; Pinto, A.; Rubio, L.I.; Martherus, R.; Bol, V.; Drozak, X.; Grégoire, V.; Riant, O.; Feron, O. Reducing the serine availability complements the inhibition of the glutamine metabolism to block leukemia cell growth. Oncotarget 2015, 7, 1765-1776. [CrossRef]

266. Białopiotrowicz, E.; Noyszewska-Kania, M.; Kachamakova-Trojanowska, N.; Łoboda, A.; Cybulska, M.; Grochowska, A.; Kopczyński, M.; Mikula, M.; Prochorec-Sobieszek, M.; Firczuk, M.; et al. Serine Biosynthesis Pathway Supports MYC-miR494-EZH2 Feed-Forward Circuit Necessary to Maintain Metabolic and Epigenetic Reprogramming of Burkitt Lymphoma Cells. Cancers 2020, 12, 580. [CrossRef]

267. Zarou, M.M.; Vazquez, A.; Helgason, G.V. Folate metabolism: A re-emerging therapeutic target in haematological cancers. Leukemia 2021, 35, 1539-1551. [CrossRef]

268. Schvartzman, J.M.; Thompson, C.B.; Finley, L.W. Metabolic regulation of chromatin modifications and gene expression. J. Cell Biol. 2018, 217, 2247-2259. [CrossRef]

269. Lu, C.; Thompson, C.B. Metabolic Regulation of Epigenetics. Cell Metab. 2012, 16, 9-17. [CrossRef]

270. Wong, C.C.; Qian, Y.; Yu, J. Interplay between epigenetics and metabolism in oncogenesis: Mechanisms and therapeutic approaches. Oncogene 2017, 36, 3359-3374. [CrossRef]

271. Järviaho, T.; Hurme-Niiranen, A.; Soini, H.K.; Niinimäki, R.; Möttönen, M.; Savolainen, E.; Hinttala, R.; Harila-Saari, A.; Uusimaa, J. Novel non-neutral mitochondrial DNA mutations found in childhood acute lymphoblastic leukemia. Clin. Genet. 2017, 93, 275-285. [CrossRef] [PubMed]

272. Tong, L.; Xu, N.; Zhou, X.; Huang, J.; Wan-Er, W.; Chen, C.; Liang, L.; Liu, Q.; Xiaoli, L. PKM2 Mediates Chronic Myeloid Leukemia Imatinib Resistance By Regulating Glycolysis Energy Metabolism. Blood 2018, 132, 1724. [CrossRef]

273. Evens, A.M.; Schumacker, P.T.; Helenowski, I.B.; Singh, A.T.K.; Dokic, D.; Keswani, A.; Kordeluk, E.; Raji, A.; Winter, J.N.; Jovanovic, B.D.; et al. Hypoxia inducible factor-alpha activation in lymphoma and relationship to the thioredoxin family. Br. J. Haematol. 2008, 141, 676-680. [CrossRef]

274. Giatromanolaki, A.; Koukourakis, M.I.; Pezzella, F.; Sivridis, E.; Turley, H.; Harris, A.L.; Gatter, K.C. Phosphorylated VEGFR2/KDR receptors are widely expressed in B-cell non-Hodgkin's lymphomas and correlate with hypoxia inducible factor activation. Hematol. Oncol. 2008, 26, 219-224. [CrossRef]

275. Wellmann, S.; Guschmann, M.; Griethe, W.; Eckert, C.; Stackelberg, A.; Lottaz, C.; Moderegger, E.; Einsiedel, H.G.; Eckardt, K.-U.; Henze, G.; et al. Activation of the HIF pathway in childhood ALL, prognostic implications of VEGF. Leukemia 2004, 18, 926-933. [CrossRef]

276. Rai, Y.; Yadav, P.; Kumari, N.; Kalra, N.; Bhatt, A.N. Hexokinase II inhibition by 3-bromopyruvate sensitizes myeloid leukemic cells K-562 to anti-leukemic drug, daunorubicin. Biosci. Rep. 2019, 39. [CrossRef]

277. He, Y.; Wang, Y.; Liu, H.; Xu, X.; He, S.; Tang, J.; Huang, Y.; Miao, X.; Wu, Y.; Wang, Q.; et al. Pyruvate kinase isoform M2 (PKM2) participates in multiple myeloma cell proliferation, adhesion and chemoresistance. Leuk. Res. 2015, 39, 1428-1436. [CrossRef]

278. Ikeda, S.; Abe, F.; Matsuda, Y.; Kitadate, A.; Takahashi, N.; Tagawa, H. Hypoxia-inducible hexokinase-2 enhances anti-apoptotic function via activating autophagy in multiple myeloma. Cancer Sci. 2020, 111, 4088-4101. [CrossRef] [PubMed]

279. Deng, Y.; Li, X.; Feng, J.; Zhang, X. Overexpression of miR-202 resensitizes imatinib resistant chronic myeloid leukemia cells through targetting Hexokinase 2. Biosci. Rep. 2018, 38. [CrossRef] [PubMed]

280. Zhang, L.-F.; Jiang, S.; Liu, M.-F. MicroRNA regulation and analytical methods in cancer cell metabolism. Experientia 2017, 144, 646-2941. [CrossRef] [PubMed]

281. Hu, N.; Cheng, Z.; Pang, Y.; Zhao, H.; Chen, L.; Wang, C.; Qin, T.; Li, Q.; Han, Y.; Shi, J.; et al. High expression of MiR-98 is a good prognostic factor in acute myeloid leukemia patients treated with chemotherapy alone. J. Cancer 2019, 10, 178-185. [CrossRef]

282. Xia, L.; Jiang, Y.; Zhang, X.-H.; Wang, X.-R.; Wei, R.; Qin, K.; Lu, Y. SUMOylation disassembles the tetrameric pyruvate kinase M2 to block myeloid differentiation of leukemia cells. Cell Death Dis. 2021, 12, 1-13. [CrossRef]

283. Wardell, S.E.; Ilkayeva, O.R.; Wieman, H.L.; Frigo, D.E.; Rathmell, J.C.; Newgard, C.B.; McDonnell, D.P. Glucose Metabolism as a Target of Histone Deacetylase Inhibitors. Mol. Endocrinol. 2009, 23, 388-401. [CrossRef]

284. McDonnell, S.R.P.; Hwang, S.; Rolland, D.; Murga-Zamalloa, C.; Basrur, V.; Conlon, K.P.; Fermin, D.; Wolfe, T.; Raskind, A.; Ruan, C.; et al. Integrated phosphoproteomic and metabolomic profiling reveals NPM-ALK-mediated phosphorylation of PKM2 and metabolic reprogramming in anaplastic large cell lymphoma. Blood 2013, 122, 958-968. [CrossRef]

285. Nie, Z.-Y.; Liu, X.-J.; Zhan, Y.; Liu, M.-H.; Zhang, X.-Y.; Li, Z.-Y.; Lu, Y.-Q.; Luo, J.-M.; Yang, L. miR-140-5p induces cell apoptosis and decreases Warburg effect in chronic myeloid leukemia by targeting SIX1. Biosci. Rep. 2019, 39. [CrossRef]

286. Sun, Y.; Zhao, X.; Zhou, Y.; Hu, Y. miR-124, miR-137 and miR-340 regulate colorectal cancer growth via inhibition of the Warburg effect. Oncol. Rep. 2012, 28, 1346-1352. [CrossRef]

287. Agirre, X.; Vilas-Zornoza, A.; Jiménez-Velasco, A.; Martin-Subero, J.I.; Cordeu, L.; Garate, L.; José-Eneriz, E.S.; Abizanda, G.; Rodriguez-Otero, P.; Fortes, P.; et al. Epigenetic Silencing of the Tumor Suppressor MicroRNA Hsa-miR-124a Regulates CDK6 Expression and Confers a Poor Prognosis in Acute Lymphoblastic Leukemia. Cancer Res. 2009, 69, 4443-4453. [CrossRef] [PubMed]

288. Wong, K.Y.; So, C.C.; Loong, F.; Chung, L.P.; Lam, W.W.L.; Liang, R.; Li, G.K.H.; Jin, N.-Y.; Chim, C. Epigenetic Inactivation of the miR-124-1 in Haematological Malignancies. PLoS ONE 2011, 6, e19027. [CrossRef] [PubMed] 
289. Jia, C.Y.; Li, H.H.; Zhu, X.C.; Dong, Y.W.; Fu, D.; Zhao, Q.L.; Wu, W.; Wu, X.Z. MiR-223 Suppresses Cell Proliferation by Targeting IGF-1R. PLoS ONE 2011, 6, e27008. [CrossRef] [PubMed]

290. Raimondi, L.; Amodio, N.; DI Martino, M.T.; Altomare, E.; Leotta, M.; Caracciolo, D.; Gullà, A.; Neri, A.; Taverna, S.; D'Aquila, P.; et al. Targeting of multiple myeloma-related angiogenesis by miR-199a-5p mimics: In vitro and in vivo anti-tumor activity. Oncotarget 2014, 5, 3039-3054. [CrossRef] [PubMed]

291. Wang, M.; Zhao, H.-Y.; Zhang, J.-L.; Wan, D.-M.; Li, Y.-M.; Jiang, Z.-X. Dysregulation of LncRNA ANRIL mediated by miR-411-3p inhibits the malignant proliferation and tumor stem cell like property of multiple myeloma via hypoxia-inducible factor $1 \alpha$. Exp. Cell Res. 2020, 396, 112280. [CrossRef]

292. Ghosh, A.K.; Shanafelt, T.D.; Cimmino, A.; Taccioli, C.; Volinia, S.; Liu, C.-G.; Calin, G.A.; Croce, C.M.; Chan, D.A.; Giaccia, A.J.; et al. Aberrant regulation of pVHL levels by microRNA promotes the HIF/VEGF axis in CLL B cells. Blood 2009, 113, 5568-5574. [CrossRef]

293. Takeuchi, A.; Nishioka, C.; Ikezoe, T.; Yang, J.; Yokoyama, A. STAT5A regulates DNMT3A in CD34+/CD38- AML cells. Leuk. Res. 2015, 39, 897-905. [CrossRef]

294. Luo, J.; Mu, J.; Zhang, M.; Zhao, B.; Liu, L. SPAG6-silencing enhances decitabine-induced apoptosis and demethylation of PTEN in SKM-1 cells and in a xenograft mouse model. Leuk. Lymphoma 2021, 1-12. [CrossRef]

295. Piras, G.; Monne, M.; Palmas, A.D.; Calvisi, A.; Asproni, R.; Vacca, F.; Pilo, L.; Gabbas, A.; Latte, G. Methylation analysis of the phosphates and tensin homologue on chromosome 10 gene (PTEN) in multiple myeloma. Clin. Epigenetics 2014, 6, 16. [CrossRef]

296. Kanduri, M.; Cahill, N.; Göransson, H.; Enström, C.; Ryan, F.; Isaksson, A.; Rosenquist, R. Differential genome-wide array-based methylation profiles in prognostic subsets of chronic lymphocytic leukemia. Blood 2010, 115, 296-305. [CrossRef] [PubMed]

297. Labno-Kirszniok, K.; Nieszporek, T.; Wiecek, A.; Helbig, G.; Lubinski, J. Acute myeloid leukemia in a 38-year-old hemodialyzed patient with von Hippel-Lindau disease. Hered. Cancer Clin. Pract. 2013, 11, 11. [CrossRef] [PubMed]

298. Place, T.L.; Fitzgerald, M.P.; Venkataraman, S.; Vorrink, S.U.; Case, A.J.; Teoh, M.L.T.; Domann, F.E. Aberrant Promoter CpG Methylation Is a Mechanism for Impaired PHD3 Expression in a Diverse Set of Malignant Cells. PLoS ONE 2011, 6, e14617. [CrossRef] [PubMed]

299. Li, Y.; Gao, L.; Luo, X.; Wang, L.; Gao, X.; Wang, W.; Sun, J.; Dou, L.; Li, J.; Xu, C.; et al. Epigenetic silencing of microRNA-193a contributes to leukemogenesis in $\mathrm{t}(8 ; 21)$ acute myeloid leukemia by activating the PTEN/PI3K signal pathway. Blood 2013, 121, 499-509. [CrossRef] [PubMed]

300. Ohguchi, H.; Hideshima, T.; Bhasin, M.; Gorgun, G.T.; Santo, L.; Cea, M.; Samur, M.K.; Mimura, N.; Suzuki, R.; Tai, Y.-T.; et al. The KDM3A-KLF2-IRF4 axis maintains myeloma cell survival. Nat. Commun. 2016, 7, 10258. [CrossRef]

301. Li, P.; Yang, X.; Cheng, Y.; Zhang, X.; Yang, C.; Deng, X.; Li, P.; Tao, J.; Yang, H.; Wei, J.; et al. MicroRNA-218 Increases the Sensitivity of Bladder Cancer to Cisplatin by Targeting Glut1. Cell. Physiol. Biochem. 2017, 41, 921-932. [CrossRef]

302. Liu, M.; Gao, J.; Huang, Q.; Jin, Y.; Wei, Z. Downregulating microRNA-144 mediates a metabolic shift in lung cancer cells by regulating GLUT1 expression. Oncol. Lett. 2016, 11, 3772-3776. [CrossRef] [PubMed]

303. Zhao, Q.; Li, J.; Chen, S.; Shen, K.; Ai, G.; Dai, X.; Xie, B.; Shi, Y.; Jiang, S.; Feng, J.; et al. Decreased miR-144 expression as a non-invasive biomarker for acute myeloid leukemia patients. Die Pharm. 2017, 72, 232-235.

304. Gupta, N.; Kumar, R.; Sharma, A. Inhibition of miR-144/199 promote myeloma pathogenesis via upregulation of versican and FAK/STAT3 signaling. Mol. Cell. Biochem. 2021, 476, 2551-2559. [CrossRef] [PubMed]

305. Zhao, Y.; Xie, Z.; Lin, J.; Liu, P. MiR-144-3p inhibits cell proliferation and induces apoptosis in multiple myeloma by targeting c-Met. Am. J. Transl. Res. 2017, 9, 2437-2446.

306. Chen, H.; Cao, W.; Chen, J.; Liu, D.; Zhou, L.; Du, F.; Zhu, F. miR-218 contributes to drug resistance in multiple myeloma via targeting LRRC28. J. Cell. Biochem. 2021, 122, 305-314. [CrossRef]

307. Jiang, L.; Meng, W.; Yu, G.; Yin, C.; Wang, Z.; Liao, L.; Meng, F. MicroRNA-144 targets APP to regulate AML1/ETO+ leukemia cell migration via the p-ERK/c-Myc/MMP-2 pathway. Oncol. Lett. 2019, 18, 2034-2042. [CrossRef]

308. Li, Z.; Wong, K.Y.; Calin, G.A.; Chng, W.-J.; Chan, G.C.-F.; Chim, C.S. Epigenetic silencing of miR-340-5p in multiple myeloma: Mechanisms and prognostic impact. Clin. Epigenetics 2019, 11, 1-13. [CrossRef]

309. Wang, Q.; Feng, T.; Xu, J.; Miao, M.; Ji, X.; Zhu, H.; Shao, X. Low expression of microRNA-340 confers adverse clinical outcome in patients with acute myeloid leukemia. J. Cell. Physiol. 2018, 234, 4200-4205. [CrossRef]

310. King, B.; Esguerra, J.L.S.; Golec, E.; Eliasson, L.; Kemper, C.; Blom, A.M. CD46 Activation Regulates miR-150-Mediated Control of GLUT1 Expression and Cytokine Secretion in Human CD4+ T Cells. J. Immunol. 2016, 196, 1636-1645. [CrossRef]

311. Srutova, K.; Curik, N.; Burda, P.; Savvulidi, F.G.; Silvestri, G.; Trotta, R.; Klamova, H.; Pecherkova, P.; Sovova, Z.; Koblihova, J.; et al. BCR-ABL1 mediated miR-150 downregulation through MYC contributed to myeloid differentiation block and drug resistance in chronic myeloid leukemia. Haematologica 2018, 103, 2016-2025. [CrossRef] [PubMed]

312. Jiang, X.; Chen, J. miR-150: Targeting MLL leukemia. Oncotarget 2012, 3, 1268-1269. [CrossRef] [PubMed]

313. Liu, Y.; Li, Q.; Dai, Y.; Jiang, T.; Zhou, Y. miR-532-3p Inhibits Proliferation and Promotes Apoptosis of Lymphoma Cells by Targeting $\beta$-Catenin. J. Cancer 2020, 11, 4762-4770. [CrossRef] [PubMed]

314. Liu, Z.; Smith, K.R.; Khong, H.T.; Huang, J.; Ahn, E.-Y.E.; Zhou, M.; Tan, M. miR-125b regulates differentiation and metabolic reprogramming of $\mathrm{T}$ cell acute lymphoblastic leukemia by directly targeting A20. Oncotarget 2016, 7, 78667-78679. [CrossRef] [PubMed] 
315. Tili, E.; Michaille, J.-J.; Luo, Z.; Volinia, S.; Rassenti, L.Z.; Kipps, T.J.; Croce, C.M. The down-regulation of miR-125b in chronic lymphocytic leukemias leads to metabolic adaptation of cells to a transformed state. Blood 2012, 120, 2631-2638. [CrossRef] [PubMed]

316. Chow, T.-F.F.; Mankaruos, M.; Scorilas, A.; Youssef, Y.; Girgis, A.; Mossad, S.; Metias, S.; Rofael, Y.; Honey, R.J.; Stewart, R.; et al. The miR-17-92 Cluster is Over Expressed in and Has an Oncogenic Effect on Renal Cell Carcinoma. J. Urol. 2010, 183, 743-751. [CrossRef]

317. Zhao, D.; Chen, Y.; Chen, S.; Zheng, C.; Hu, J.; Luo, S. MiR-19a regulates the cell growth and apoptosis of osteosarcoma stem cells by targeting PTEN. Tumor Biol. 2017, 39. [CrossRef]

318. Hao, M.; Zang, M.; Wendlandt, E.; Xu, Y.; An, G.; Gong, D.; Li, F.; Qi, F.; Zhang, Y.; Yang, Y.; et al. Low serum miR-19a expression as a novel poor prognostic indicator in multiple myeloma. Int. J. Cancer 2014, 136, 1835-1844. [CrossRef]

319. Cao, L.; Wang, N.; Pan, J.; Hu, S.; Zhao, W.; He, H.; Wang, Y.; Gu, G.; Chai, Y. Clinical significance of microRNA-34b expression in pediatric acute leukemia. Mol. Med. Rep. 2016, 13, 2777-2784. [CrossRef]

320. Wu, H.; Wang, X.; Wu, T.; Yang, S. miR-489 suppresses multiple myeloma cells growth through inhibition of LDHA-mediated aerobic glycolysis. Genes Genom. 2019, 42, 291-297. [CrossRef]

321. Qi, H.-X.; Cao, Q.; Zhou, G.-P.; Sun, X.-Z.; Zhou, W.-D.; Hong, Z.; Hu, J.; Juan, C.-X.; Li, S.; Kuai, W.-X. MicroRNA 34b inhibits cell proliferation in pediatric acute myeloid leukemia via regulating LDHA. Eur. Rev. Med. Pharmacol. Sci. 2019, 23, 5351-5359.

322. Calin, G.A.; Cimmino, A.; Fabbri, M.; Ferracin, M.; Wojcik, S.E.; Shimizu, M.; Taccioli, C.; Zanesi, N.; Garzon, R.; Aqeilan, R.I.; et al. MiR-15a and miR-16-1 cluster functions in human leukemia. Proc. Natl. Acad. Sci. USA 2008, 105, 5166-5171. [CrossRef]

323. Kohrogi, K.; Hino, S.; Sakamoto, A.; Anan, K.; Takase, R.; Araki, H.; Hino, Y.; Araki, K.; Sato, T.; Nakamura, K.; et al. LSD1 defines erythroleukemia metabolism by controlling the lineage-specific transcription factors GATA1 and C/EBP $\alpha$. Blood Adv. 2021, 5, 2305-2318. [CrossRef]

324. Madan, V.; Koeffler, H.P. Differentiation therapy of myeloid leukemia: Four decades of development. Haematologica 2020, 106, 1-13. [CrossRef]

325. Jones, C.L.; Stevens, B.M.; Pollyea, D.A.; Culp-Hill, R.; Reisz, J.A.; Nemkov, T.; Gehrke, S.; Gamboni, F.; Krug, A.; Winters, A.; et al. Nicotinamide Metabolism Mediates Resistance to Venetoclax in Relapsed Acute Myeloid Leukemia Stem Cells. Cell Stem Cell 2020, 27, 748-764.e4. [CrossRef] [PubMed]

326. Manier, S.; Powers, J.T.; Sacco, A.; Glavey, S.V.; Huynh, D.; Reagan, M.R.; Salem, K.Z.; Moschetta, M.; Shi, J.; Mishima, Y.; et al. The LIN28B/let-7 axis is a novel therapeutic pathway in multiple myeloma. Leukemia 2016, 31, 853-860. [CrossRef] [PubMed]

327. Zhou, J.; Bi, C.; Ching, Y.Q.; Chooi, J.-Y.; Lu, X.; Quah, J.Y.; Toh, S.H.-M.; Chan, Z.-L.; Tan, T.Z.; Chong, P.S.; et al. Inhibition of LIN28B impairs leukemia cell growth and metabolism in acute myeloid leukemia. J. Hematol. Oncol. 2017, 10, 138. [CrossRef] [PubMed]

328. Wang, T.; Wang, G.; Hao, D.; Liu, X.; Wang, D.; Ning, N.; Li, X. Aberrant regulation of the LIN28A/LIN28B and let-7 loop in human malignant tumors and its effects on the hallmarks of cancer. Mol. Cancer 2015, 14, 1-13. [CrossRef]

329. Chen, B.; Liu, Y.; Jin, X.; Lu, W.; Liu, J.; Xia, Z.; Yuan, Q.; Zhao, X.; Xu, N.; Liang, S. MicroRNA-26a regulates glucose metabolism by direct targeting PDHX in colorectal cancer cells. BMC Cancer 2014, 14, 443. [CrossRef]

330. Zhu, Y.; Wu, G.; Yan, W.; Zhan, H.; Sun, P. MiR-146b-5p Regulates Cell Growth, Invasion, and Metabolism by Targeting PDHB in Colorectal Cancer. Am. J. Cancer Res. 2017, 7, 1136.

331. Wei, S.; Ma, W. MiR-370 functions as oncogene in melanoma by direct targeting pyruvate dehydrogenase B. Biomed. Pharmacother. 2017, 90, 278-286. [CrossRef]

332. Hu, Y.; Liu, H.; Fang, C.; Li, C.; Xhyliu, F.; Dysert, H.; Bodo, J.; Habermehl, G.; Russell, B.E.; Li, W.; et al. Targeting of CD38 by the tumor suppressor miR-26a serves as a novel potential therapeutic agent in multiple myeloma. Cancer Res. 2020. [CrossRef] [PubMed]

333. Tu, Z.; Xiong, J.; Xiao, R.; Shao, L.; Yang, X.; Zhou, L.; Yuan, W.; Wang, M.; Yin, Q.; Wu, Y.; et al. Loss of miR-146b-5p promotes $\mathrm{T}$ cell acute lymphoblastic leukemia migration and invasion via the IL-17A pathway. J. Cell. Biochem. 2018, 120, 5936-5948. [CrossRef] [PubMed]

334. Zhang, X.; Zeng, J.; Zhou, M.; Li, B.; Zhang, Y.; Huang, T.; Wang, L.; Jia, J.; Chen, C. The tumor suppressive role of miRNA-370 by targeting FoxM1 in acute myeloid leukemia. Mol. Cancer 2012, 11, 56. [CrossRef] [PubMed]

335. D'Abundo, L.; Callegari, E.; Bresin, A.; Chillemi, A.; Elamin, B.K.; Guerriero, P.; Huang, X.; Saccenti, E.; Hussein, E.M.; Casciano, F.; et al. Anti-leukemic activity of microRNA-26a in a chronic lymphocytic leukemia mouse model. Oncogene 2017, 36, 6617-6626. [CrossRef] [PubMed]

336. Dong, J.; Xiao, D.; Zhao, Z.; Ren, P.; Li, C.; Hu, Y.; Shi, J.; Su, H.; Wang, L.; Liu, H.; et al. Epigenetic silencing of microRNA-137 enhances ASCT2 expression and tumor glutamine metabolism. Oncogenesis 2017, 6, e356. [CrossRef] [PubMed]

337. Qin, Y.; Zhang, S.; Deng, S.; An, G.; Qin, X.; Li, F.; Xu, Y.; Hao, M.; Yang, Y.; Zhou, W.; et al. Epigenetic silencing of miR-137 induces drug resistance and chromosomal instability by targeting AURKA in multiple myeloma. Leukemia 2016, 31, 1123-1135. [CrossRef]

338. Huang, Y.; Zou, Y.; Zheng, R.; Ma, X. MiR-137 inhibits cell proliferation in acute lymphoblastic leukemia by targeting JARID1B. Eur. J. Haematol. 2019, 103, 215-224. [CrossRef] 
339. Zhang, T.-J.; Qian, Z.; Wen, X.-M.; Zhou, J.-D.; Li, X.-X.; Xu, Z.-J.; Ma, J.-C.; Zhang, Z.-H.; Lin, J.; Qian, J. Lower expression of bone marrow miR-122 is an independent risk factor for overall survival in cytogenetically normal acute myeloid leukemia. Pathol. Res. Pr. 2018, 214, 896-901. [CrossRef]

340. Wang, N.; Tan, H.-Y.; Feng, Y.-G.; Zhang, C.; Chen, F.; Feng, Y. microRNA-23a in Human Cancer: Its Roles, Mechanisms and Therapeutic Relevance. Cancers 2018, 11, 7. [CrossRef]

341. Jeong, S.M.; Haigis, A.M.C. Sirtuins in Cancer: A Balancing Act between Genome Stability and Metabolism. Mol. Cells 2015, 38, 750-758. [CrossRef] [PubMed]

342. Farhana, A.; Lappin, S.L. Biochemistry, Lactate Dehydrogenase; StatPearls: Treasure Island, FL, USA, 2021.

343. Li, X.; Kazgan, N. Mammalian Sirtuins and Energy Metabolism. Int. J. Biol. Sci. 2011, 7, 575-587. [CrossRef] [PubMed]

344. Dominy, J.E.; Lee, Y.; Jedrychowski, M.P.; Chim, H.; Jurczak, M.; Camporez, J.P.; Ruan, H.-B.; Feldman, J.; Pierce, K.; Mostoslavsky, R.; et al. The Deacetylase Sirt6 Activates the Acetyltransferase GCN5 and Suppresses Hepatic Gluconeogenesis. Mol. Cell 2012, 48, 900-913. [CrossRef]

345. Lee, J.V.; Carrer, A.; Shah, S.; Snyder, N.; Wei, S.; Venneti, S.; Worth, A.J.; Yuan, Z.-F.; Lim, H.-W.; Liu, S.; et al. Akt-Dependent Metabolic Reprogramming Regulates Tumor Cell Histone Acetylation. Cell Metab. 2014, 20, 306-319. [CrossRef] [PubMed]

346. Wellen, K.E.; Hatzivassiliou, G.; Sachdeva, U.M.; Bui, T.V.; Cross, J.; Thompson, C.B. ATP-Citrate Lyase Links Cellular Metabolism to Histone Acetylation. Science 2009, 324, 1076-1080. [CrossRef]

347. Basappa, J.; Citir, M.; Zhang, Q.; Wang, H.Y.; Liu, X.; Melnikov, O.; Yahya, H.; Stein, F.; Muller, R.; Traynor-Kaplan, A.; et al. ACLY is the novel signaling target of PIP2/PIP3 and Lyn in acute myeloid leukemia. Heliyon 2020, 6, e03910. [CrossRef]

348. Cairns, R.A.; Iqbal, J.; Lemonnier, F.; Kucuk, C.; de Leval, L.; Jais, J.-P.; Parrens, M.; Martin, A.; Xerri, L.; Brousset, P.; et al. IDH2 mutations are frequent in angioimmunoblastic T-cell lymphoma. Blood 2012, 119, 1901-1903. [CrossRef]

349. Trissal, M.C.; Wong, T.N.; Yao, J.-C.; Ramaswamy, R.; Kuo, I.; Baty, J.D.; Sun, Y.; Jih, G.; Parikh, N.; Berrien-Elliott, M.M.; et al MIR142 loss-of-function mutations derepress ASH1L to increase HOXA gene expression and promote leukemogenesis. Cancer Res. 2018. [CrossRef]

350. Raffel, S.; Falcone, M.; Kneisel, N.; Hansson, J.; Wang, W.; Lutz, C.; Bullinger, L.; Poschet, G.; Nonnenmacher, Y.; Barnert, A.; et al. BCAT1 restricts $\alpha$ KG levels in AML stem cells leading to IDHmut-like DNA hypermethylation. Nature 2017, 551, 384-388, [CrossRef]

351. Xiao, M.; Yang, H.; Xu, W.; Ma, S.; Lin, H.; Zhu, H.; Liu, L.; Liu, Y.; Yang, C.; Xu, Y.; et al. Inhibition of -KG-dependent histone and DNA demethylases by fumarate and succinate that are accumulated in mutations of FH and SDH tumor suppressors. Genes Dev. 2012, 26, 1326-1338. [CrossRef]

352. Killian, J.K.; Kim, S.Y.; Miettinen, M.; Smith, C.; Merino, M.; Tsokos, M.; Quezado, M.; Smith, W.I.; Jahromi, M.S.; Xekouki, P.; et al. Succinate Dehydrogenase Mutation Underlies Global Epigenomic Divergence in Gastrointestinal Stromal Tumor. Cancer Discov. 2013, 3, 648-657. [CrossRef] [PubMed]

353. Letouzé, E.; Martinelli, C.; Loriot, C.; Burnichon, N.; Abermil, N.; Ottolenghi, C.; Janin, M.; Menara, M.; Nguyen, A.T.; Benit, P.; et al. SDH Mutations Establish a Hypermethylator Phenotype in Paraganglioma. Cancer Cell 2013, 23, 739-752. [CrossRef] [PubMed]

354. Li, M.; Chiang, Y.-L.; Lyssiotis, C.; Teater, M.R.; Hong, J.Y.; Shen, H.; Wang, L.; Hu, J.; Jing, H.; Chen, Z.; et al. Non-oncogene Addiction to SIRT3 Plays a Critical Role in Lymphomagenesis. Cancer Cell 2019, 35, 916-931.e9. [CrossRef] [PubMed]

355. Bradbury, C.A.; Khanim, F.L.; Hayden, R.; Bunce, C.; White, D.A.; Drayson, M.; Craddock, C.; Turner, B.M. Histone deacetylases in acute myeloid leukaemia show a distinctive pattern of expression that changes selectively in response to deacetylase inhibitors. Leukemia 2005, 19, 1751-1759. [CrossRef]

356. Jeong, S.M.; Xiao, C.; Finley, L.W.; Lahusen, T.; Souza, A.L.; Pierce, K.; Li, Y.-H.; Wang, X.; Laurent, G.; German, N.J.; et al. SIRT4 Has Tumor-Suppressive Activity and Regulates the Cellular Metabolic Response to DNA Damage by Inhibiting Mitochondrial Glutamine Metabolism. Cancer Cell 2013, 23, 450-463. [CrossRef]

357. Wei, W.; Sun, W.; Yu, S.; Yang, Y.; Ai, L. Butyrate production from high-fiber diet protects against lymphoma tumor. Leuk. Lymphoma 2016, 57, 2401-2408. [CrossRef]

358. Latham, T.; Mackay, L.; Sproul, D.; Karim, M.; Culley, J.; Harrison, D.; Hayward, L.; Langridge-Smith, P.; Gilbert, N.; Ramsahoye, B.H. Lactate, a product of glycolytic metabolism, inhibits histone deacetylase activity and promotes changes in gene expression. Nucleic Acids Res. 2012, 40, 4794-4803. [CrossRef]

359. Momparler, R.L.; Côté, S.; Momparler, L.F.; Idaghdour, Y. Epigenetic therapy of acute myeloid leukemia using 5-aza-2'deoxycytidine (decitabine) in combination with inhibitors of histone methylation and deacetylation. Clin. Epigenetics 2014, 6, 19. [CrossRef] [PubMed]

360. Wang, Z.; Yip, L.Y.; Lee, J.H.J.; Wu, Z.; Chew, H.Y.; Chong, P.K.W.; Teo, C.C.; Ang, H.Y.-K.; Peh, K.L.E.; Yuan, J.; et al. Methionine is a metabolic dependency of tumor-initiating cells. Nat. Med. 2019, 25, 825-837. [CrossRef]

361. Phillips, C.M.; Zatarain, J.R.; Nicholls, M.E.; Porter, C.; Widen, S.G.; Thanki, K.; Johnson, P.; Jawad, M.U.; Moyer, M.P.; Randall, J.W.; et al. Upregulation of Cystathionine- $\beta$-Synthase in Colonic Epithelia Reprograms Metabolism and Promotes Carcinogenesis. Cancer Res. 2017, 77, 5741-5754. [CrossRef] [PubMed]

362. Mudd, S.H.; Cerone, R.; Schiaffino, M.C.; Fantasia, A.R.; Minniti, G.; Caruso, U.; Lorini, R.; Watkins, D.; Matiaszuk, N.; Rosenblatt, D.S.; et al. GlycineN-methyltransferase deficiency: A novel inborn error causing persistent isolated hypermethioninaemia. J. Inherit. Metab. Dis. 2001, 24, 448-464. [CrossRef] 
363. Sperber, H.; Mathieu, J.; Wang, Y.; Ferreccio, A.; Hesson, J.; Xu, Z.; Fischer, K.A.; Devi, A.; Detraux, D.; Gu, H.; et al. The metabolome regulates the epigenetic landscape during naive-to-primed human embryonic stem cell transition. Nature 2015, 17, 1523-1535. [CrossRef]

364. Ulanovskaya, O.A.; Zuhl, A.M.; Cravatt, B.F. NNMT promotes epigenetic remodeling in cancer by creating a metabolic methylation sink. Nat. Chem. Biol. 2013, 9, 300-306. [CrossRef]

365. de Jonge, R.; Tissing, W.J.E.; Hooijberg, J.H.; Jansen, G.; Kaspers, G.J.L.; Lindemans, J.; Peters, G.J.; Pieters, R. Polymorphisms in folate-related genes and risk of pediatric acute lymphoblastic leukemia. Blood 2009, 113, 2284-2289. [CrossRef] [PubMed]

366. Nylund, P.; Párraga, A.A.; Haglöf, J.; De Bruyne, E.; Menu, E.; Garrido-Zabala, B.; Ma, A.; Jin, J.; Öberg, F.; Vanderkerken, K.; et al. A distinct metabolic response characterizes sensitivity to EZH2 inhibition in multiple myeloma. Cell Death Dis. 2021, 12, 1-16. [CrossRef] [PubMed]

367. Salati, S.; Salvestrini, V.; Carretta, C.; Genovese, E.; Rontauroli, S.; Zini, R.; Rossi, C.; Ruberti, S.; Bianchi, E.; Barbieri, G.; et al. Deregulated expression of miR-29a-3p, miR-494-3p and miR-660-5p affects sensitivity to tyrosine kinase inhibitors in CML leukemic stem cells. Oncotarget 2017, 8, 49451-49469. [CrossRef] [PubMed]

368. Tian, C.; Zheng, G.; Zhuang, H.; Li, X.; Hu, D.; Zhu, L.; Wang, T.; You, M.J.; Zhang, Y. MicroRNA-494 Activation Suppresses Bone Marrow Stromal Cell-Mediated Drug Resistance in Acute Myeloid Leukemia Cells. J. Cell. Physiol. 2016, 232, 1387-1395. [CrossRef] [PubMed]

369. Chen, K.; Chen, Y.; Chen, Z.; Shi, Y.; He, Z.; Ding, B.; Wang, C.; Yu, L. miR-134 increases the antitumor effects of cytarabine by targeting Mnks in acute myeloid leukemia cells. OncoTargets Ther. 2018, ume 11, 3141-3147. [CrossRef]

370. Tian, C.; Zhang, L.; Li, X.; Zhang, Y.; Li, J.; Chen, L. Low miR-192 expression predicts poor prognosis in pediatric acute myeloid leukemia. Cancer Biomark. 2018, 22, 209-215. [CrossRef] [PubMed]

371. Sun, Y.; Pan, J.; Mao, S.; Jin, J. IL-17/miR-192/IL-17Rs Regulatory Feedback Loop Facilitates Multiple Myeloma Progression. PLoS ONE 2014, 9, e114647. [CrossRef] [PubMed]

372. Zhu, F.; Guo, H.; Bates, P.D.; Zhang, S.; Zhang, H.; Nomie, K.J.; Li, Y.; Lu, L.; Seibold, K.R.; Wang, F.; et al. PRMT5 is upregulated by B-cell receptor signaling and forms a positive-feedback loop with PI3K/AKT in lymphoma cells. Leukemia 2019, 33, $2898-2911$. [CrossRef] [PubMed]

373. Yu, J.; Batova, A.; Shao, L.; Carrera, C.J.; Yu, A. Presence of methylthioadenosine phosphorylase (MTAP) in hematopoietic stem/progenitor cells: Its therapeutic implication for MTAP (-) malignancies. Clin. Cancer Res. 1997, 3, 433-438. [PubMed]

374. Nepali, K.; Liou, J.-P. Recent developments in epigenetic cancer therapeutics: Clinical advancement and emerging trends. J. Biomed. Sci. 2021, 28, 1-58. [CrossRef]

375. Danenberg, P.V.; Gustavsson, B.; Johnston, P.; Lindberg, P.; Moser, R.; Odin, E.; Peters, G.J.; Petrelli, N. Folates as adjuvants to anticancer agents: Chemical rationale and mechanism of action. Crit. Rev. Oncol. 2016, 106, 118-131. [CrossRef] [PubMed]

376. Muthu, M.; Nordström, A. Current Status and Future Prospects of Clinically Exploiting Cancer-specific Metabolism-Why Is Tumor Metabolism Not More Extensively Translated into Clinical Targets and Biomarkers? Int. J. Mol. Sci. 2019, $20,1385$. [CrossRef] [PubMed] 